Cover: Pea Island 


\title{
The Outer Banks of North Carolina
}

\author{
By Robert Dolan and Harry Lins
}

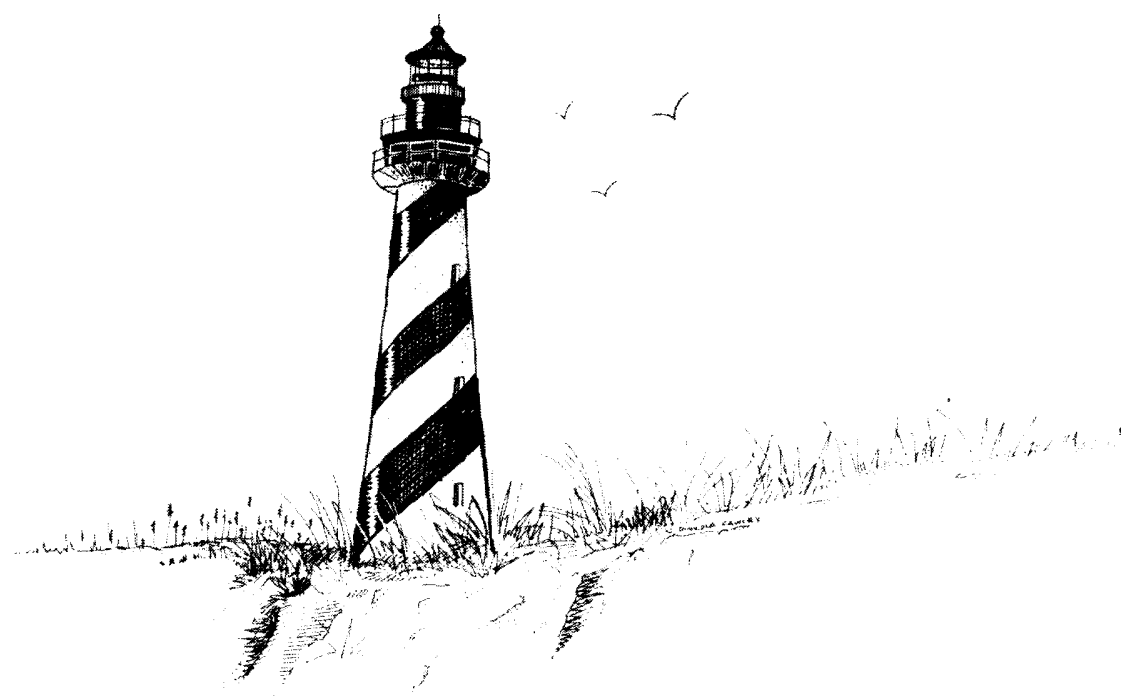

\section{U.S. Geological Survey Professional Paper 1177-B}




\title{
U.S. DEPARTMENT OF THE INTERIOR BRUCE BABBITT, Secretary
}

\author{
U.S. GEOLOGICAL SURVEY \\ Charles G. Groat, Director
}

First printing 1986

Second printing 1991

Third printing 1993

Fourth printing 2000

\section{Reston, Virginia 2000}

\section{Library of Congress Cataloging in Publications Data}

Dolan, Robert.

The Outer Banks of North Carolina.

(U.S. Geological Survey professional paper ; 1177-B)

"Prepared in cooperation with the Nationa Park Service."

Bibliography: p. 43

Supt. of Docs. no.: I 19.16: 1177B I

1. Coast changes-North Carolina-Outer Banks. 2. Shore protection-North Carolina-Outer Banks. 3. Land useNorth Carolina-Outer Banks. I. Lins, Harry F. II. United States. National Park Service. III. Title. IV. Series: U.S. Geological Survey. Professional paper; 1177-B.

GB459.4.D64 1985

$333.91^{\prime} 716^{\prime} 09756--\mathrm{dc} 21$

$85-600098$

For sale by U.S. Geological Survey, Information Services, Box 25286, Federal Center,

Denver, CO 80225 


\section{FOREWORD}

In keeping with its commitment to demonstrate and promote the application of earth-science information to sound environmental planning and decisionmaking, the U.S. Geological Survey is offering this report, Professional Paper 1177-B, which analyzes the processes and hazards associated with coastal barrier islands. This is the second of several publications that follow the style begun with Professional Paper 950, Nature to be Commanded. The first report in this series, Geological Analysis of Fenwick Island, Maryland, A Middle Atlantic Coast Barrier Island, dealt with a highly urbanized barrier island.

It is important to realize that the hazards associated with natural processes and urban development are found all along the Atlantic and Gulf coasts. This publication focuses on the North Carolina Barrier islands. These islands were selected because they are representative of many developed mid-Atlantic coast barrier islands and provide, therefore, a generally applicable example.

We believe that this book, and those that follow, will have a significant and positive effect on coastal planning. The documentation of the rates of change of natural processes and recent land use provides planners and developers with key information for guiding future development of those areas of least hazard and for evaluating alternative hazard mitigation techniques.

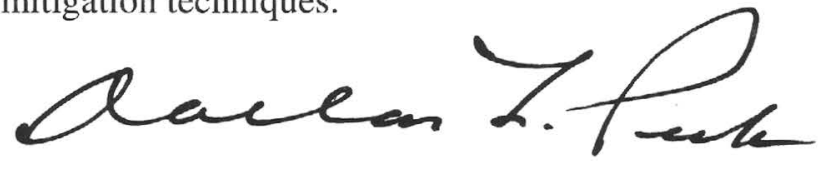

Dallas L. Peck Director

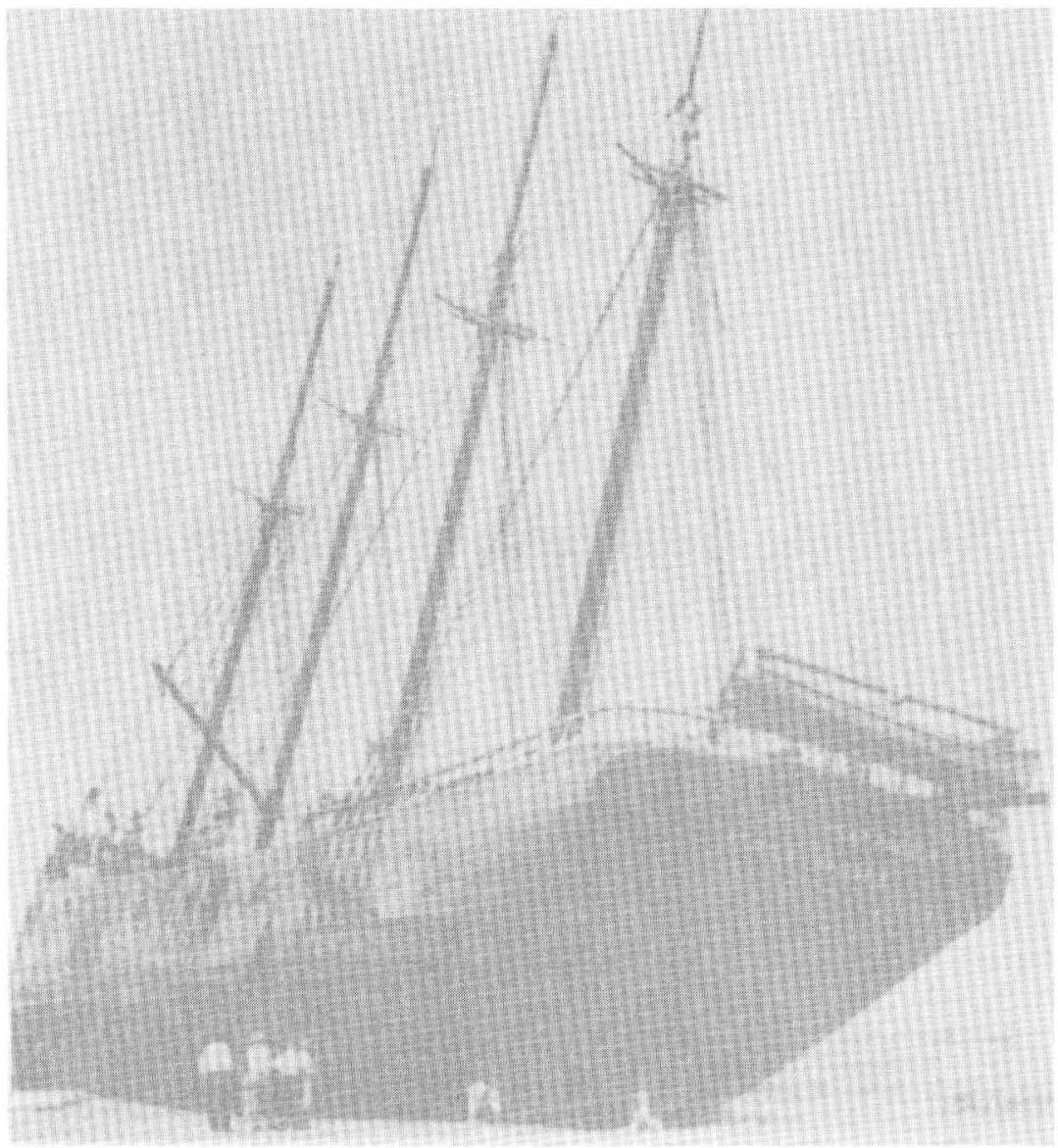





\section{CONTENTS}

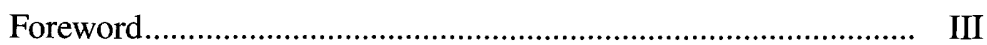

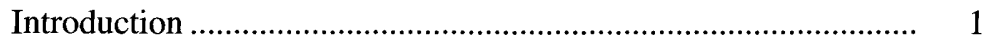

Acknowledgment .................................................................. 3

Barrier Island Dynamics.............................................................. 3

Dominant Processes................................................................... 3

Storms and Waves................................................................. 4

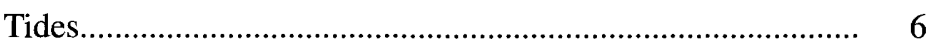

Barrier Island Landforms ............................................................. 7

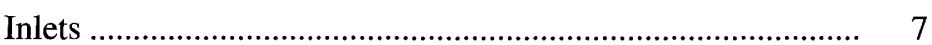

Overwash Deposits ............................................................. 10

Sand Dunes ................................................................... 10

Geological History of the Outer Banks ....................................... 12

Shoreline Configuration ....................................................... 18

History and Development ....................................................... 20

Recent Trends in Land Use .................................................... 25

Shoreline Processes: Erosion and Overwash................................ 29

Shoreline Erosion and the Lost Colony .................................. 31

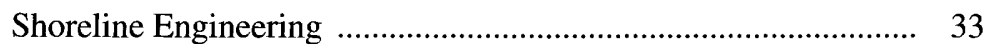

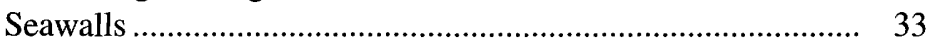

Jetties and Groins..................................................................... 33

Beach Nourishment .............................................................. 34

Inlet Stabilization............................................................... 34

Economics of Stabilization ...................................................... 34

Man's Impact on the Outer Banks ............................................... 36

Hazards and Land Use ............................................................ 43

Summary and Conclusions .......................................................... 44

Selected References ............................................................... 46 



\title{
THE OUTER BANKS OF NORTH CAROLINA
}

\author{
By Robert Dolan and Harry Lins
}

\section{INTRODUCTION}

The Outer Banks of North Carolina are some of the best examples of the nearly 300 barrier islands that rim the Atlantic and Gulf coasts (fig. 1). These low, sandy islands are among the most dynamic natural landscapes used by man. Storms are the primary cause of changes in these landscapes. During the storms, private landholdings often are destroyed, and communication and transportation facilities are disrupted. Loss of life also is not uncommon. In spite of these obvious problems, with few exceptions,

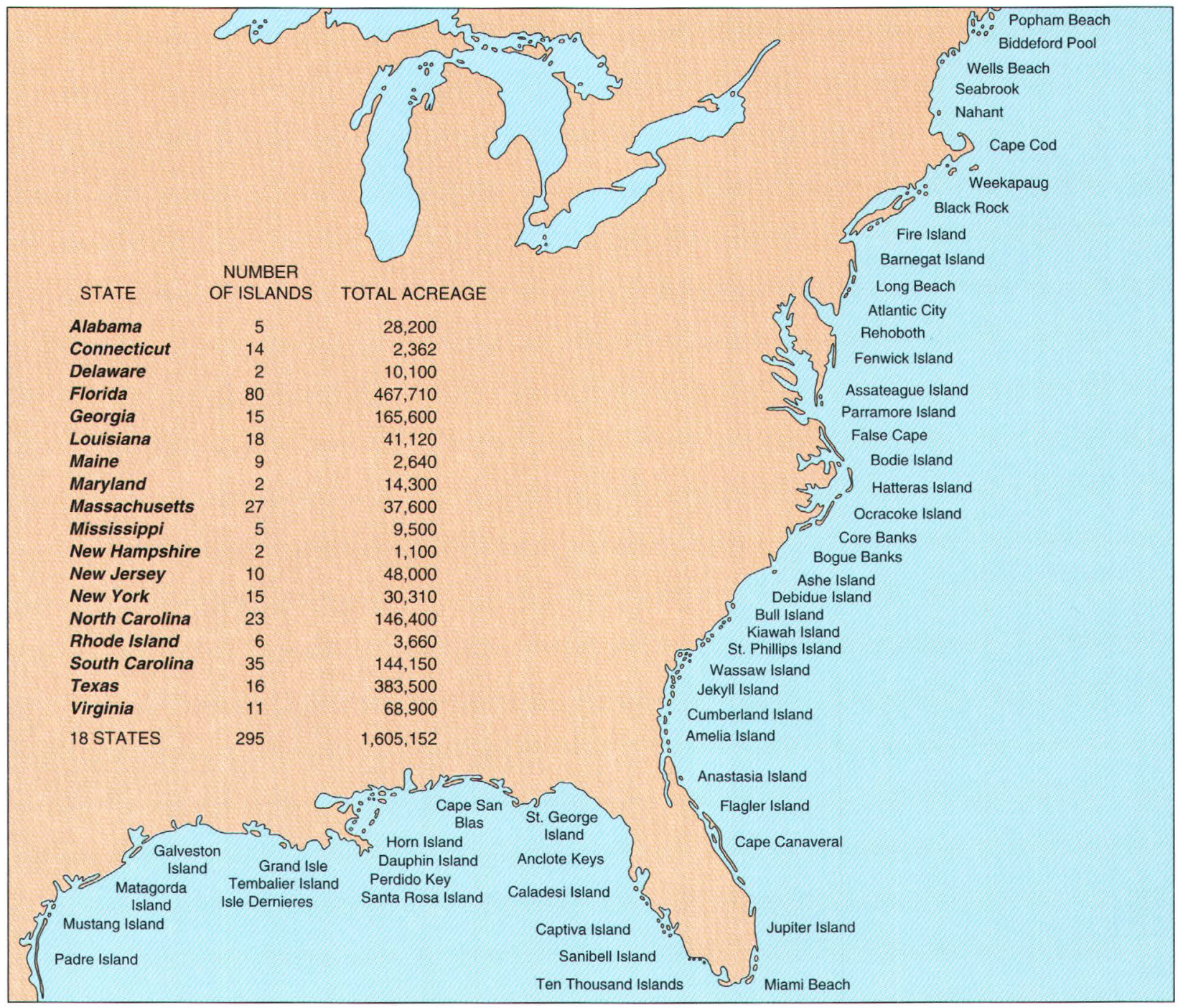

Figure 1. Along the coastline between Cape Cod, Massachusetts, and Padre Island, Texas. The widths of the 295 barrier islands have been exaggerated on this map. (Source: $R$. Dolan.) 


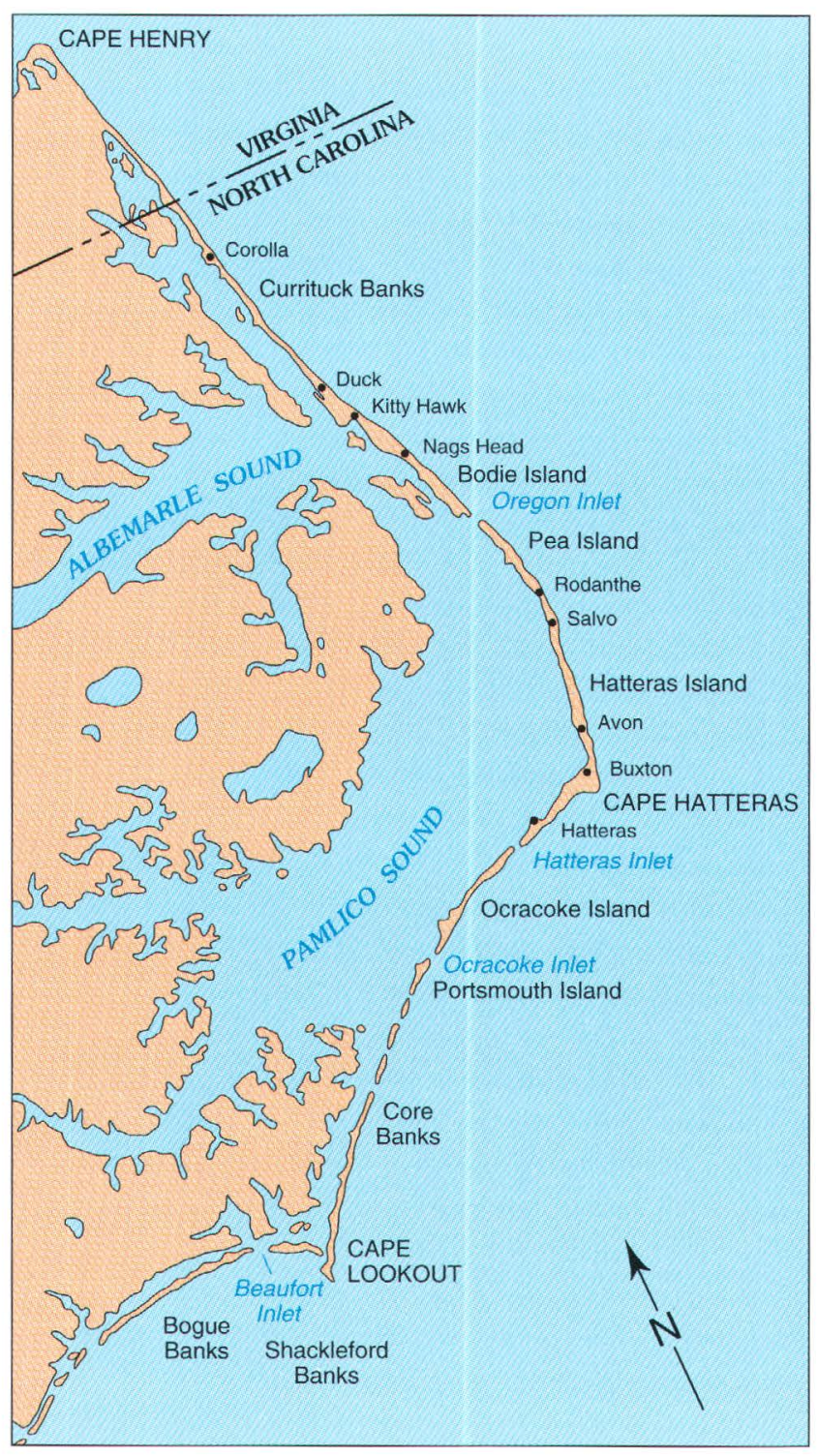

Figure 2. The Outer Banks of North Carolina. development has proceeded as if barrier islands are stable or on the assumption that at least they can be engineered to remain stable.

The dynamic nature of the beaches and dunes always has been part of the aesthetic and recreational appeal of the Outer Banks. Unfortunately, development has taken place more rapidly than our understanding of barrier island dynamics. Processes affecting the islands span time scales from hours to decades and longer and include variations in the beach during a single 12-hour tidal cycle, periodic storm surges, shoreline recession in response to long-term changes in sea level, changes in storm tracks, and islandwide modifications associated with man's activities.

The Outer Banks (fig. 2), particularly the ocean side, have always been hazardous places for man. Early inhabitants recognized this and settled the more stable parts of the islands well inland from the ocean. Over the last several decades, this pattern of land use has reversed. Much construction has taken place dangerously close to the shoreline because of a desire to be near the water's edge, even though this location clearly introduces serious risks to life and property (fig. 3).

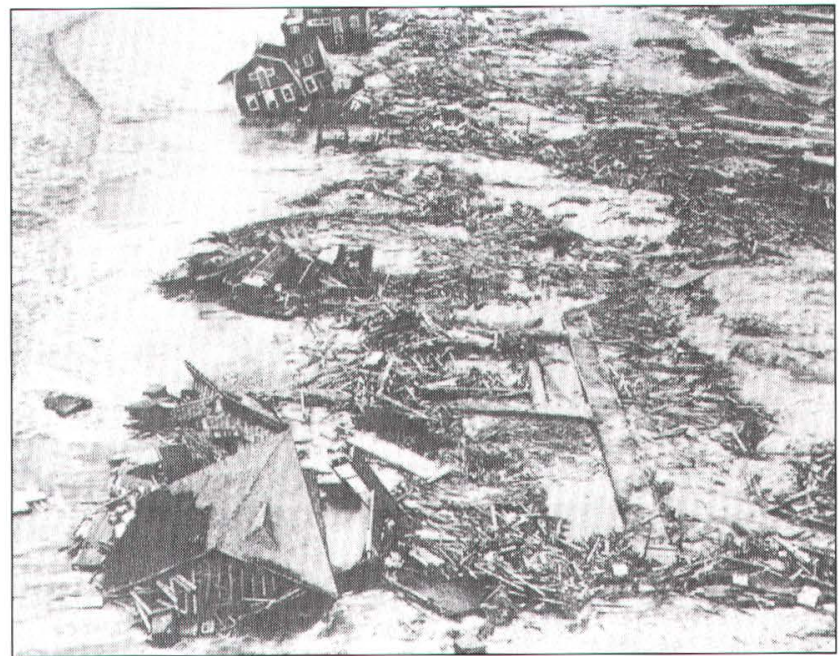

Figure 3. Damage caused by the Ash Wednesday storm of March 7, 1962. This storm caused more than $\$ 500$ million in damages between Long Island and Cape Lookout. Most of the damage occurred on the barrier islands, as seen in this view of Fire Island photographed shortly after the storm subsided. (Source: United Press International.) 
All barrier islands are the product of a gradually rising sea level, a surplus of sand supplied to the coast, and waves large enough and winds strong enough to move the sand (fig. 4). The relation of these factors is a continuously changing one.

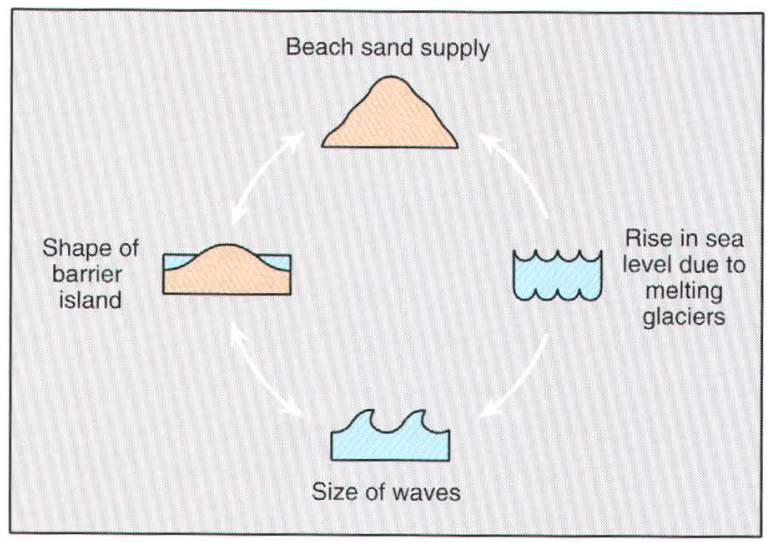

Figure 4. Simple relation among processes, sand supply, and barrier island form.

The islands are unstable because the constant movement of sand by waves and currents affects the along-the-coast shape of the islands, and the rising sea level causes their migration landward (Dolan and others, 1977). Even though unstable, barrier islands are environmentally valuable. The estuaries and sounds behind barrier islands are among the richest and most productive ecosystems known. Nurseries, shelter, and food are provided for many species of fish, shellfish, and wildlife (Livingston, 1976).

Several barrier islands have been preserved in their undeveloped state because of their environmental importance. Nine of the most scenic and natural islands or island groups have been set aside by the National Park Service as national seashores, and others are preserved as national wildlife refuges. Most coastal States have placed at least one barrier island under such Federal protection.

Although some of the Atlantic and Gulf coast barrier islands were settled during the colonial period and some were used as sources of building materials or coastal defense sites, changing economic and social conditions following World War II made the islands more desirable sites for development. Time has not changed the natural problems and hazards associated with developing barrier islands, however. It is just as unsafe to build a house on shifting sand today as it was a century ago. The dangers from hurricanes and severe northeasters are just as great, and, considering the high population density on some of the islands, the potential for a disaster is even greater.

Understanding the natural dynamics of barrier islands is the key to recognizing and estimating both the short-term and the long-term hazards of living on them. This report summarizes how the barrier islands were created, how they have changed, and why they will continue to change in spite of efforts to halt the natural processes. The Outer Banks of North Carolina are used as an example in this report, but the principles outlined are applicable to other barrier islands on the Atlantic and Gulf coasts.

\section{ACKNOWLEDGMENT}

We wish to acknowledge the assistance of Deborah Cairns in conducting the literature research necessary for the preparation of this report. 


\section{BARRIER ISLAND DYNAMICS}

The Atlantic and Gulf Coastal Plains are relatively flat and slope gently seaward to a generally wide submarine Continental Shelf. The shore zone, or interface between the land and sea portions of the coastal plain, consists of a series of barrier islands 2 to 20 miles offshore. Most are low islands 1 to 3 miles wide and 10 to 20 miles long. The highest topographic features are sand dunes usually 10 to 20 feet above sea level. In a few areas, such as Jockey Ridge near Nags Head, North Carolina, unvegetated dunes reach a maximum height of 120 feet.

\section{Dominant Processes}

The physical interface between land and sea is a zone in constant motion. On sandy coasts, each variation in sea level alters the interface. Beach sands are transported offshore, onshore, and in the direction of prevailing longshore currents. In this way, sandy coasts constantly adjust in response to different tide, wave, and current conditions. Periodic phases of erosion and deposition are superimposed on a longer term trend of a rising sea level (Hicks, 1972; Hicks and Crosby, 1975). This long-term rise submerges the beach, causes shoreline recession, and forces the barrier islands landward.

In cross section, the barrier islands of the Outer Banks are an assemblage of sedimentary layers, each made up of particles of different sizes that indicate their source and the processes responsible for their movement (fig. 5). These deposits consist primarily of medium quartz sand and a small percentage of heavy minerals, gravels, and shell fragments. Beach material is carried and deposited, layer upon layer, by one of two dominant processes-storm overwash or transport by currents flowing through inlets. Bedded within the layers of beach material are units of well-sorted finer sands and silts transported by wind. The configuration of the island, in cross section and plan view, is an integration of the along-the-coast transport of sand. The processes that formed the islands remain active today.

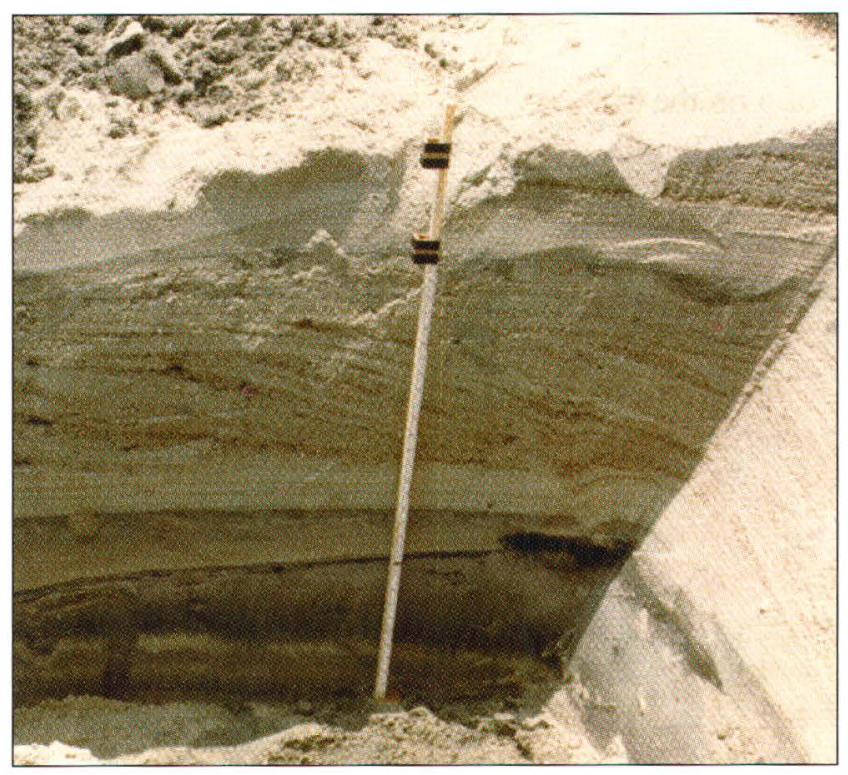

Figure 5. Primary features of an unaltered barrier island in cross section. (Source: R. Dolan.)

\section{Storms and Waves}

Hurricanes and winter extratropical storms, or "northeasters," of the midlatitudes have been the principal agents of geomorphic change on the midAtlantic barrier islands since their formation. Landscape change occurs with the movement of sand by strong wind and wave activity. Hurricanes generate high storm surges in contrast to extratropical storms that produce small to modest surges.

Since 1900, the Atlantic and Gulf coast barrier islands have been crossed by more than 100 hurricanes. About one-half of these storms have been classified by the National Oceanic and Atmospheric Administration as major storms having winds greater than 90 miles per hour and storm surges of more than 9 feet (Hebert and Taylor, 1979a, b). The two most damaging hurricanes of this century killed more than 6,000 people in Galveston, Texas, in 1900 (Hughes, 1979) and almost 2,000 people in Florida in 1928. The three costliest hurricanes in terms of property losses were Frederic in September 1979, which caused an estimated $\$ 700$ million in damage along the Gulf coast near Mobile, Alabama; Agnes in 1972, which caused \$2 billion in damage; and Camille 
in 1969, which destroyed $\$ 1.4$ billion worth of property. Camille was also one of the most intense hurricanes since 1900 , registering the maximum value of 5 on the Saffir Simpson scale, with wind speeds over 150 miles per hour and a storm surge that drove water more than 25 feet above sea level (Hebert and Taylor, 1979a, b).

Only four major hurricanes have affected the U.S. coasts since 1969. Three of these struck relatively sparsely populated areas on the Gulf coast: Celia in southern Texas in 1970, Carmen in Louisiana in 1974, and Eloise in northwest Florida in 1975. Hurricane Frederic, a class 3 hurricane on the Saffir Simpson scale, struck a densely populated area of the Gulf coast in 1979.

The last major hurricane to hit the Atlantic coast was Donna in 1960. As a result of this disparity in the frequency and distribution of major hurricanes, fewer than 20 percent of the residents of the Atlantic and Gulf coast barrier islands have ever experienced the impact of such a storm (Frank, 1979).

Between 1886 and 1970, 15 hurricanes having winds in excess of 75 miles per hour were reported along the Outer Banks, an average of about one every 7.5 years (Dunn and Miller, 1960). Hurricanes occur most commonly in early September, but the season extends from June through November.

Although hurricanes cause extensive damage and loss of life, winter extratropical storms, or "northeasters," cause most of the coastal damage along the Outer Banks. Unlike hurricanes, which form over the warm tropical waters of the Caribbean and North Atlantic, extratropical storms develop in the midlatitudes along weather fronts that separate cold, dry polar air from warm, moist tropical air. Each year between 30 and 40 such storms generate significant surges and waves of at least 5 feet (Bosserman and Dolan, 1968; Hayden, 1975). The Lincoln's Birthday northeaster of February 12-13, 1973, for example, caused severe erosion on beaches from Long Island, New York, to Miami, Florida. The great Ash Wednesday storm of March 7, 1962, produced waves more than 30 feet high, damaging millions of dollars of property along the mid-Atlantic coast (Cooperman and Rosendal, 1962; Podufaly, 1962; Stewart, 1962; U.S. Army Corps of Engineers, 1962; Bretschneider, 1964). Although the normal wave height for the Outer Banks averages from 2 to 3 feet, the cumulative effect of high tide, spring tide, storm surge, and storm waves can produce a water-level rise of up to 30 feet. This rise may result in overwashing of the foredune and flooding of the back side of the barrier island (Hosier and Cleary, 1977).

Statistics on storm occurrence and waves along the Outer Banks are presented in figure 6. The plot of storm return interval shows, for example, that a storm producing a wave height of 26 feet off Cape Hatteras can be expected to occur during a 125-year period.

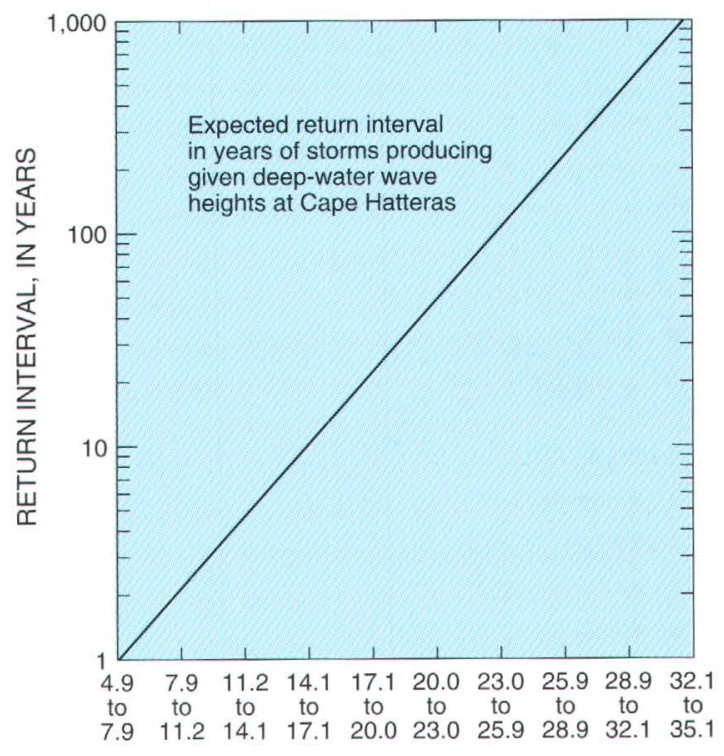

DEEP-WATER WAVE HEIGHT, IN FEET

Figure 6. Expected return interval in years of storms producing given wave heights offshore of Cape Hatteras. (Source: B. Hayden.)

The average number of northeast storms per month that produce deep-water waves at least 5 feet high, based on 32 years of wave data, is shown in figure 7 . It is evident from this graph that the stormiest months are from December to March.

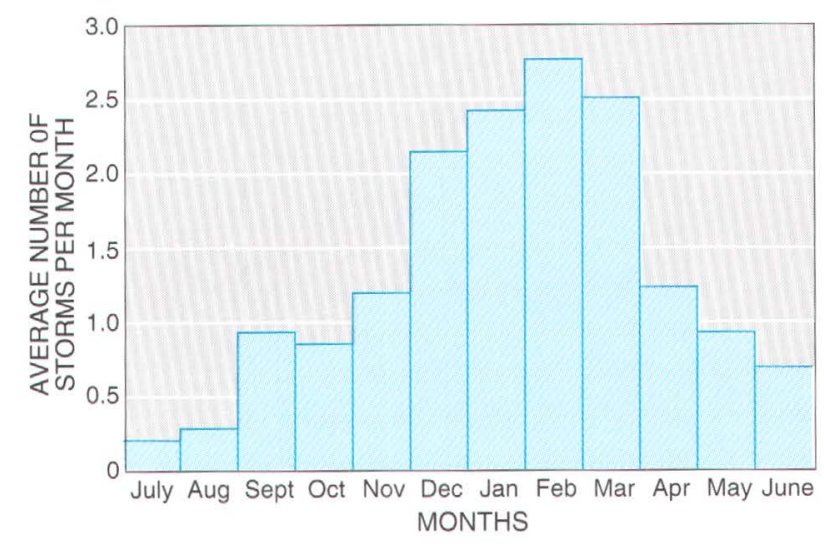

Figure 7. Monthly distribution of storms producing deepwater waves in excess of 5 feet in height. (Source: B. Hayden.) 


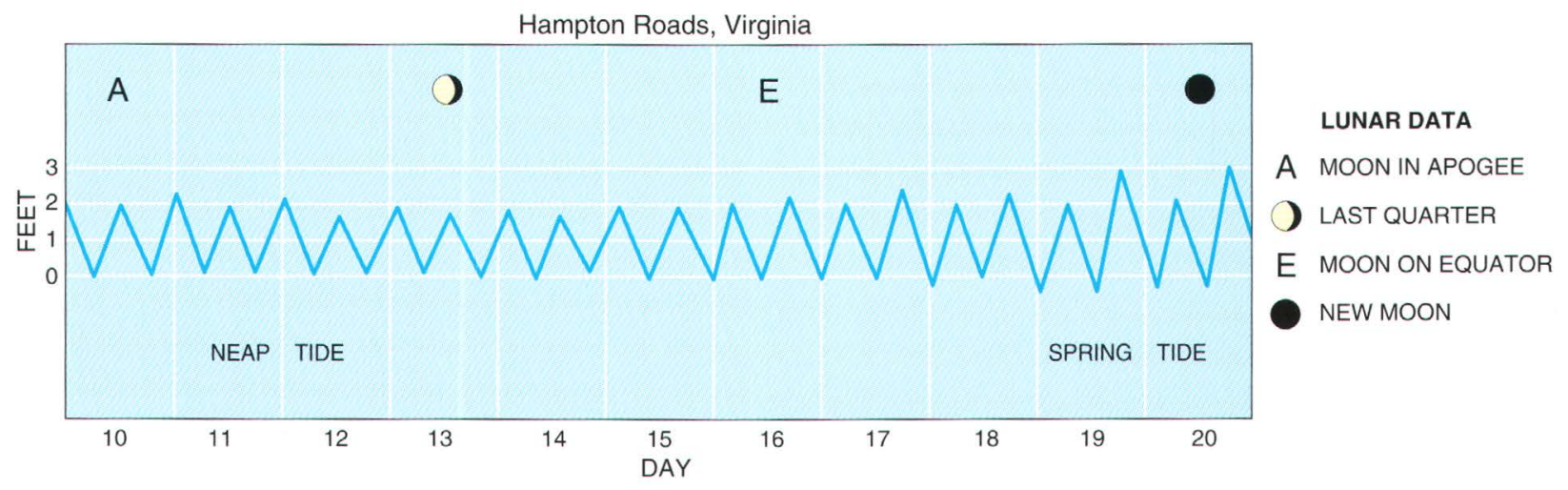

Figure 8. Representative tide curve for Hampton Roads, Virginia, of the mid-Atlantic coast. The tide type is semidiurnal with the principal variations following the changes in the Moon's phase. Tide range for the Outer Banks is 2 to 4 feet.

\section{Tides}

The water level of the sea is constantly changing. Gradual variations in water level occur through tides (fig. 8), storm waves, and storm surge and through long-term sea-level fluctuations (fig. 9). The astronomical tides along the Outer Banks are semidiurnal (12 hours and 25 minutes apart) with an average range of 3.5 feet. The highest, or spring, tides occur twice each month when the Earth, Moon, and Sun are alined, increasing the tidal range approximately 20 percent. Tidal action alone has little effect on sediment transport. When storm surge and high waves are superimposed, however, the daily elevation and depression of the water level becomes a more important agent in sediment transport (fig. 10).

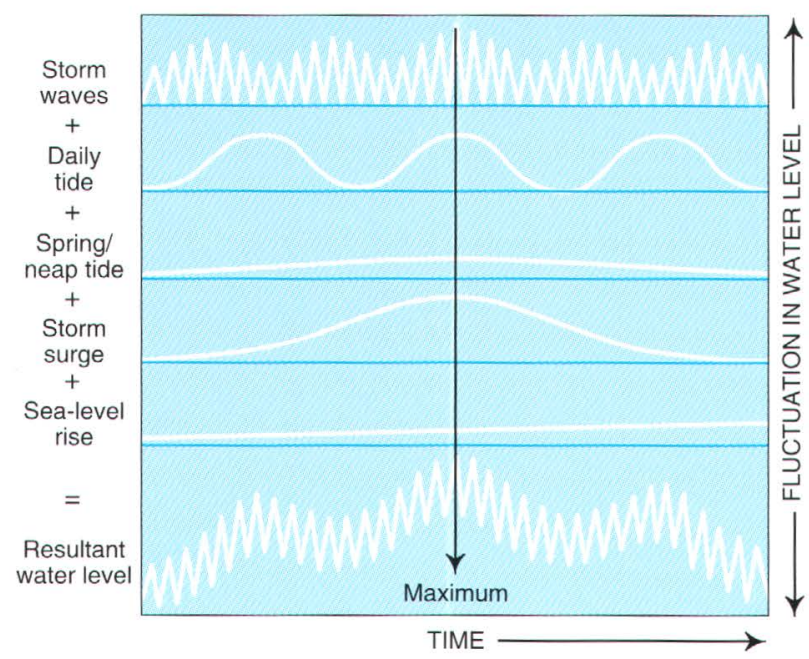

Figure 9. Sea-level variations occur over a wide range of time intervals.

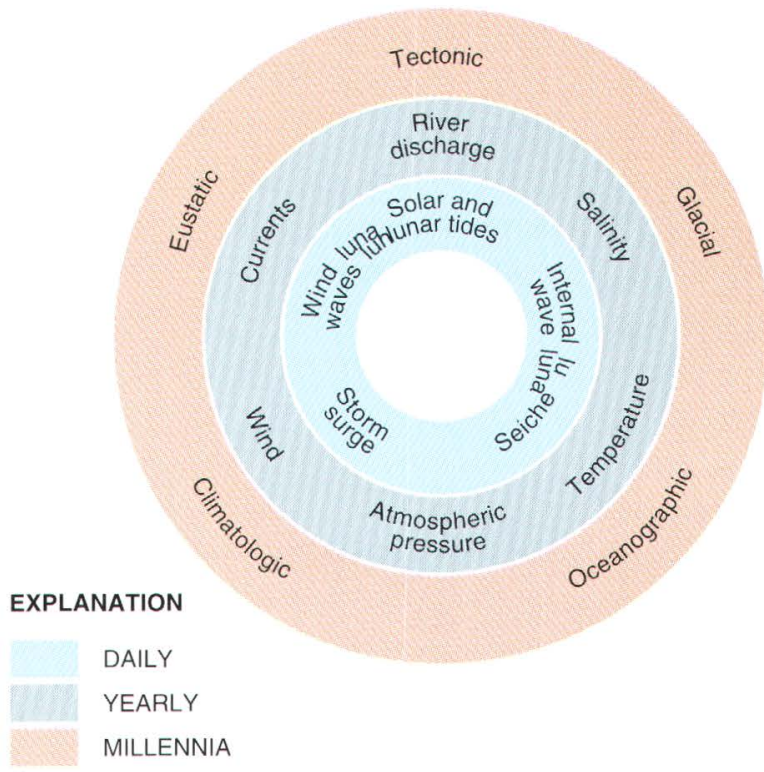

Figure 10. Cumulative effects of coastal processes on water level.

As a result of the Moon's elliptical orbit, a minimal lunar perigee occurs once during each lunar cycle. When this happens, higher tides, called perigean spring tides, are generated. A recent National Oceanographic and Atmospheric Administration report (Wood, 1976) shows a strong coincidence of catastrophic storms and perigean spring tides. One hundred of the most severe coastal storms between 1635 and 1976 occurred at the time of the perigean spring tides. The Ash Wednesday storm of 1962 is an example of a severe storm that occurred during a perigean spring tide. 


\section{BARRIER ISLAND LANDFORMS}

Continuous changes in sea level, wave action, storm surge, and sediment supply lead to rapid changes in barrier island landforms. These processes vary over an infinite variety of individual actions. The following principal classes of sand movement, however, are responsible for most changes occurring on barrier islands (fig. 11).

\section{Movement along the shore zone: Waves}

approaching the coast at an angle set up sediment-transporting processes along the coast called longshore currents. The direction and strength of these currents depend on wave height and wave direction. Over the course of a year, there is usually a net flow of water and sediment, such as littoral drift, in one direction. Along the Outer Banks, this direction is southward toward Cape Hatteras and Cape Lookout (Pierce, 1969).

2. Movement across the shore zone: During periods of very high waves and tides, water levels along the barrier islands may rise so high that the beach may be overwashed by water and sediment traveling across the island (Pierce, 1970; Schwartz, 1975). Beach sediment also is transported offshore by surf-zone processes and is deposited by longshore currents at other sections of the coast. Inlets also provide a means for movement of sediment from the beach zone to the sounds.

3. Movement by wind action: Fine sand from the beach face, sand flats, and dunes can be transported across and along the islands by strong winds.

FOUR METHODS OF SEDIMENT TRANSPORT

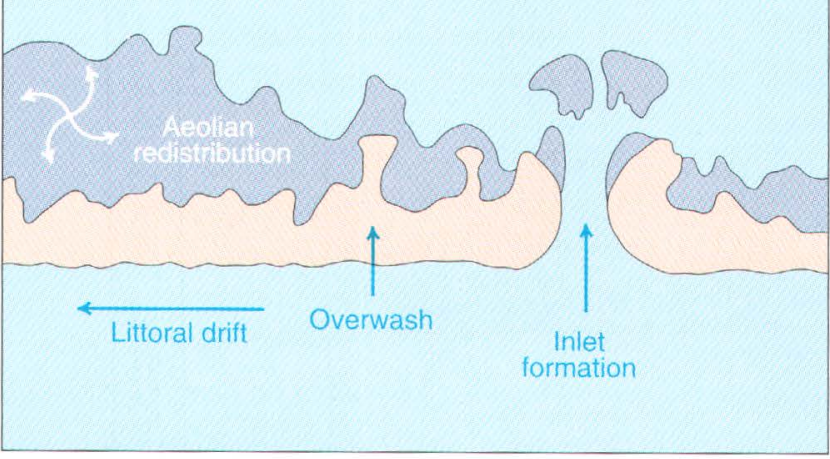

Figure 11. The primary methods of sediment transport on Atlantic coast beaches and barrier islands.

\section{Inlets}

Inlets are formed when storm surge and high waves drive water across the islands to the sounds (fig. 12). As the seawater moves across the island, usually into areas of progressively lower topography, channels form and may erode to the depths that permit a reverse flow (sound to sea) during ebb tide. Most such inlets are temporary features of elevated water levels that last a few days.

The formation of inlets has important geologic and ecologic implications (Godfrey, 1970). Great quantities of saline water and sediment are moved through the inlets from the ocean side of the islands to the sounds (Moslow and Heron, 1979). The water contains nutrients and organisms, and the sediment forms shoals that provide new substrates for marsh grasses. Soon after the inlets close, the shoals are incorporated into the island substrate. Inlet formation and closure are, therefore, the fundamental sedimenttransfer processes during which material moves from the ocean side to the sound side of the barrier islands (fig. 13). The deposits that fill inlets are believed to comprise a relatively large percentage of barrier island sediments, perhaps as much as 20 to 25 percent. This amount depends upon the number and duration of inlet openings. In a study along North Carolina's Core Banks, Moslow and Heron (1978) calculated that 14 to 16 percent of the Holocene sediments consists of inlet fill material.

The geological and cultural histories of the Outer Banks are tied to the history of inlets along the barrier islands (Dunbar, 1958). Up to 30 inlets have opened and closed since the first settlers arrived almost 400 years ago (fig. 14). During the past 125 years, however, three inlets have remained open as dominant waterways along the coast: Ocracoke, Hatteras, and Oregon. The latter two inlets were formed during the same storm in 1846 (Fisher, 1962). 

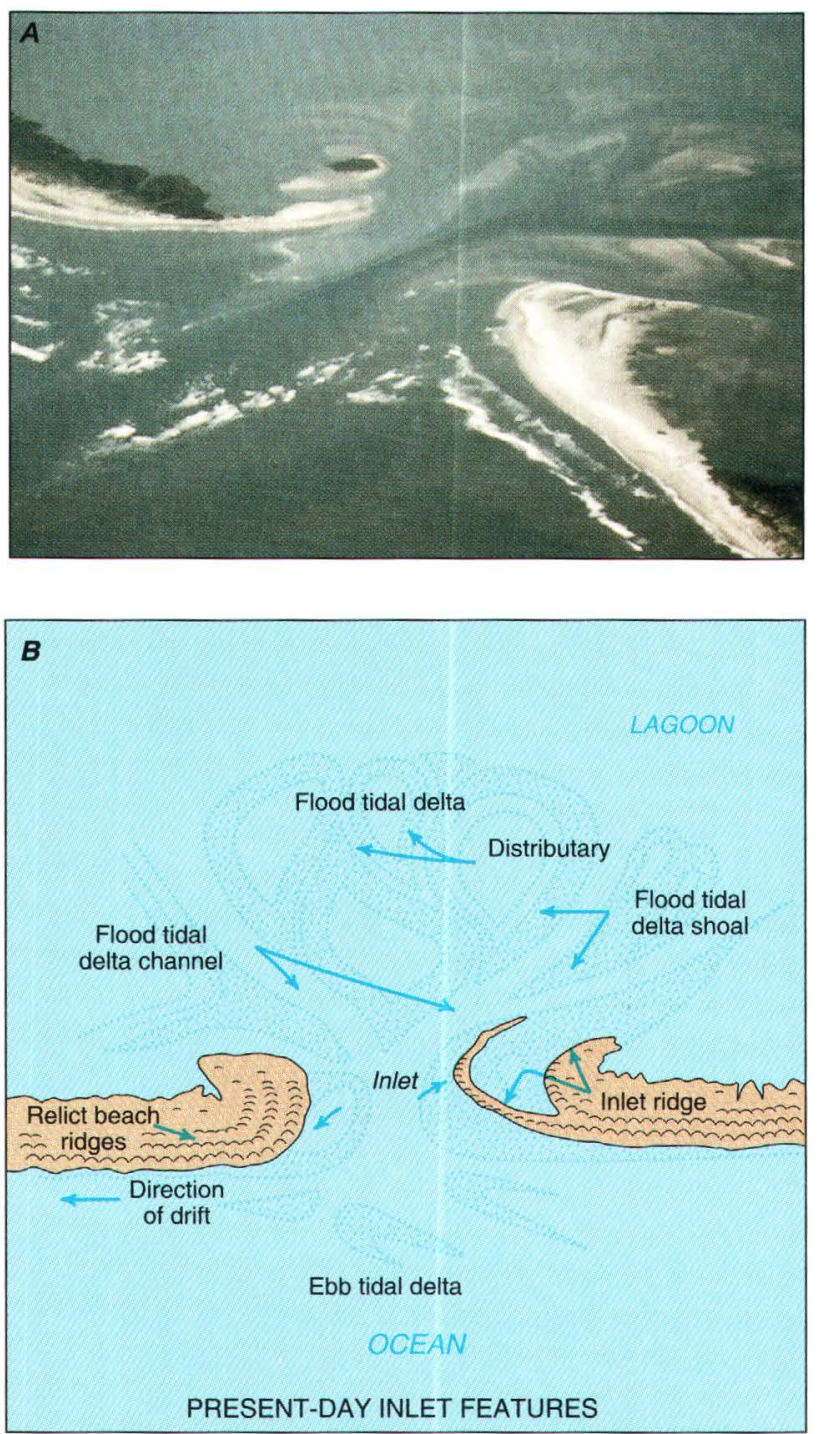

Figure 12. Features of inlet sedimentation. New lands are created as tidal deltas become vegetated. A, Floodtide delta in upper right of photgraph, ebbtide delta in lower left. B, Diagram of inlet features. C, Inlet features following inlet closure. (Source: J. Fisher.)

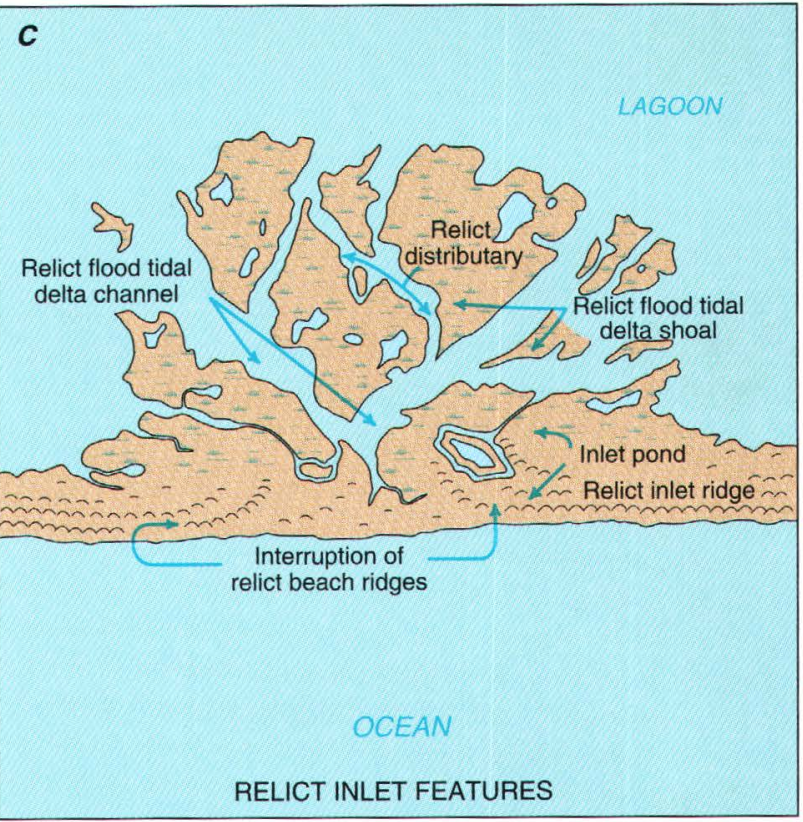

Figure 13. The pattern of clearly evident oceanic overwash and inlet sedimentation on the bay side of Pea Island. (Source: R. Dolan.)

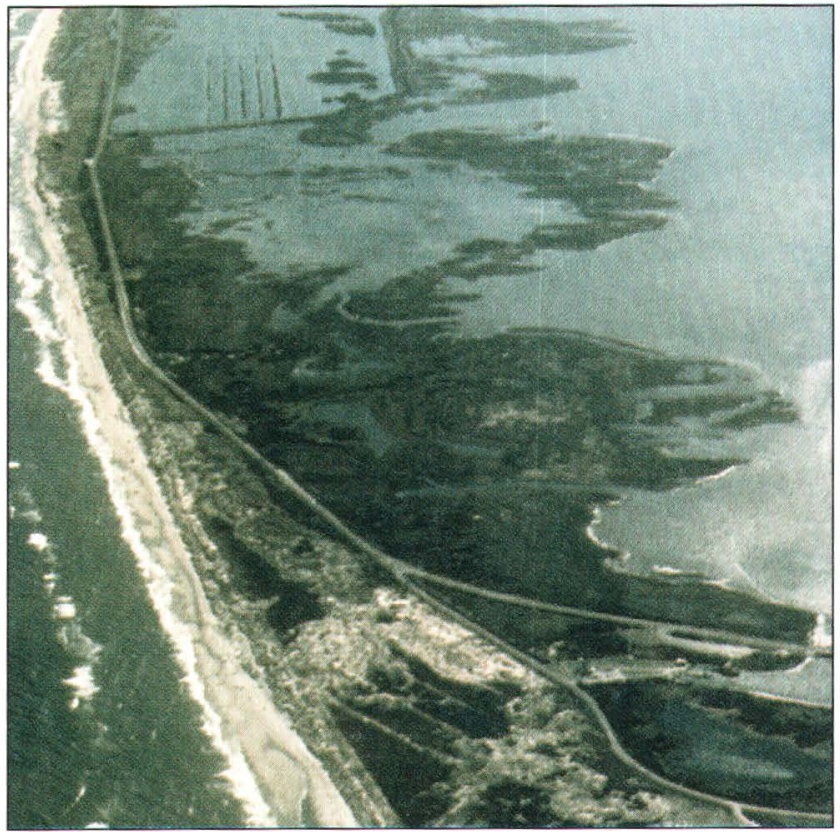




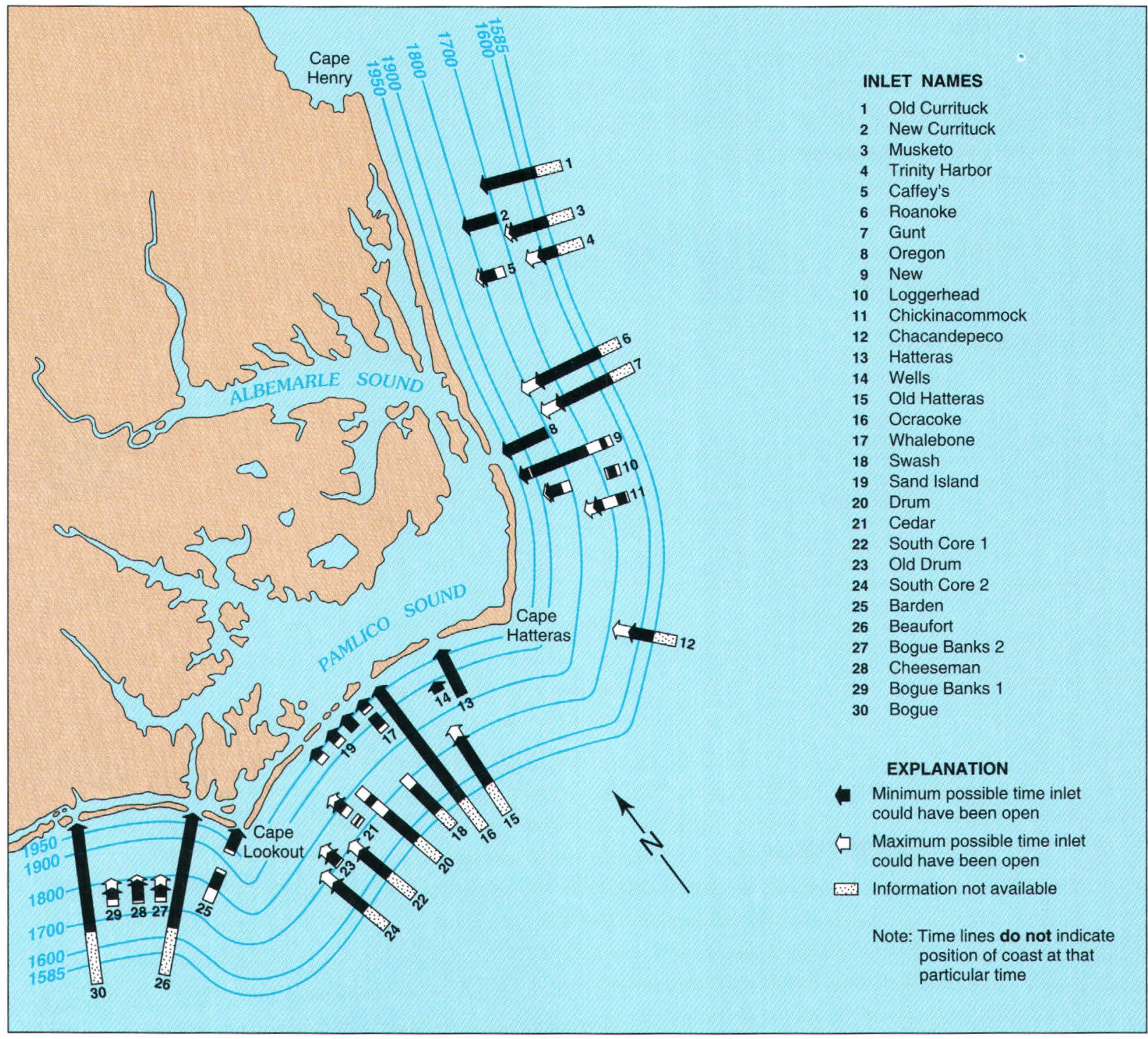

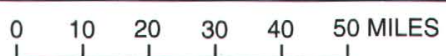

Figure 14. The distribution of historic inlets along the Outer Banks. (Source: J. Fisher.) 


\section{Overwash Deposits}

Beaches constantly change in response to different wave and tide conditions. When waves are high, the active beach zone expands both landward and seaward, but it contracts when waves are low. During hurricanes and other severe storms, the beach undergoes major adjustments to dissipate the increased wave energy. If the waves and surge are very high, the runup can extend into zones normally associated with wind-blown deposits. This penetration of water and sediment is called overwash (fig. 15), and the resultant deposits are known as overwash fans.

\section{Sand Dunes}

All mid-Atlantic coast barrier islands have dunes of various sizes landward of the beach. Most dune sand is transported across the beach face or backshore and is deposited within the overwash flats and vegetated zones. Depending on the grain size, wind speeds of 15 to 20 miles per hour are necessary to initiate sand movement. In areas with wide, active beaches and strong prevailing winds, large dunes may form.

The oldest and largest dunes on the Outer Banks were formed 3,000 to 4,000 years ago (Fisher, 1962). As the islands were forming, alternating periods of erosion and accretion resulted in the development of parallel dune ridges with depressions, or swales, between them. This process can be seen today near the mouths of coastal rivers that carry heavy sediment loads. The best examples on the Outer Banks of large, stable dune ridges are found at Buxton, Colington Island, and Nags Head Woods. These dunes are covered with maritime forests of pine and oak and are the most stable landscapes along the Outer Banks. When the parallel dunes are breached or the vegetation cover is destroyed, the dunes become a major source of sand for redistribution by the wind. In some places, this source of sand has resulted in new dune fields of significantly different configurations. Jockey Ridge, the highest dune on the Atlantic coast, is an example (fig. 16).
The high beach foredunes, also called barrier dunes, are primarily a product of man's efforts to stabilize the sand movement along the Outer Banks (Dolan, Geofrey, and Odum, 1973). If sand fences are placed just inland from the beach face, the flow of air carrying sand is disrupted, and the sand accumulates as a ridge or dune at the base of the fence. If vegetation (fig. 17) and fertilizer are introduced, as they were along the Outer Banks in the 1960's, it is possible to build, or encourage nature to build, a very large, parallel dune. Such dunes began to appear on the Outer Banks after 1930, when public works programs started large-scale sand stabilization projects.

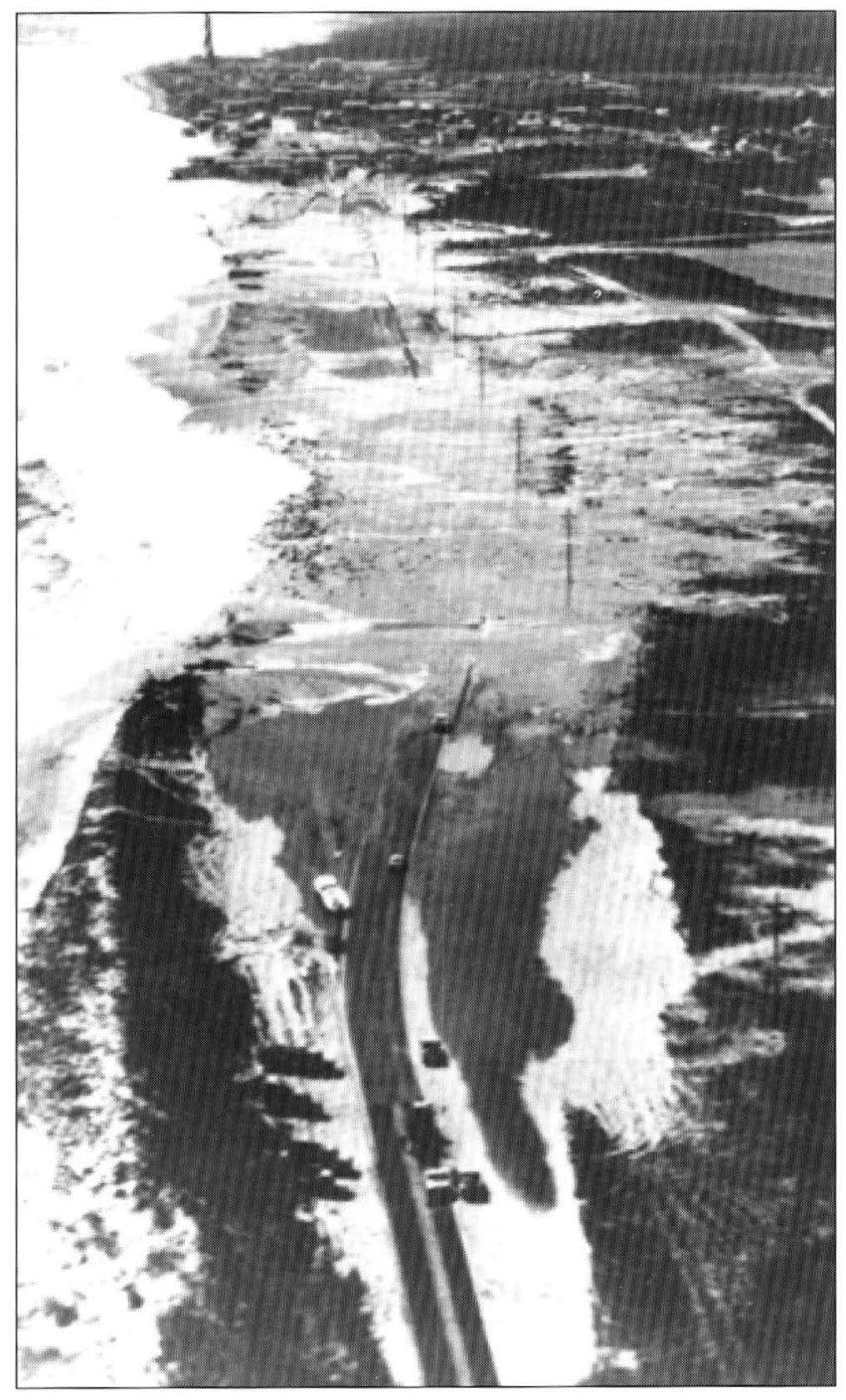

Figure 15. Pattern of overwash and storm-surge penetration near Cape Hatteras. (Source: R. Dolan.) 


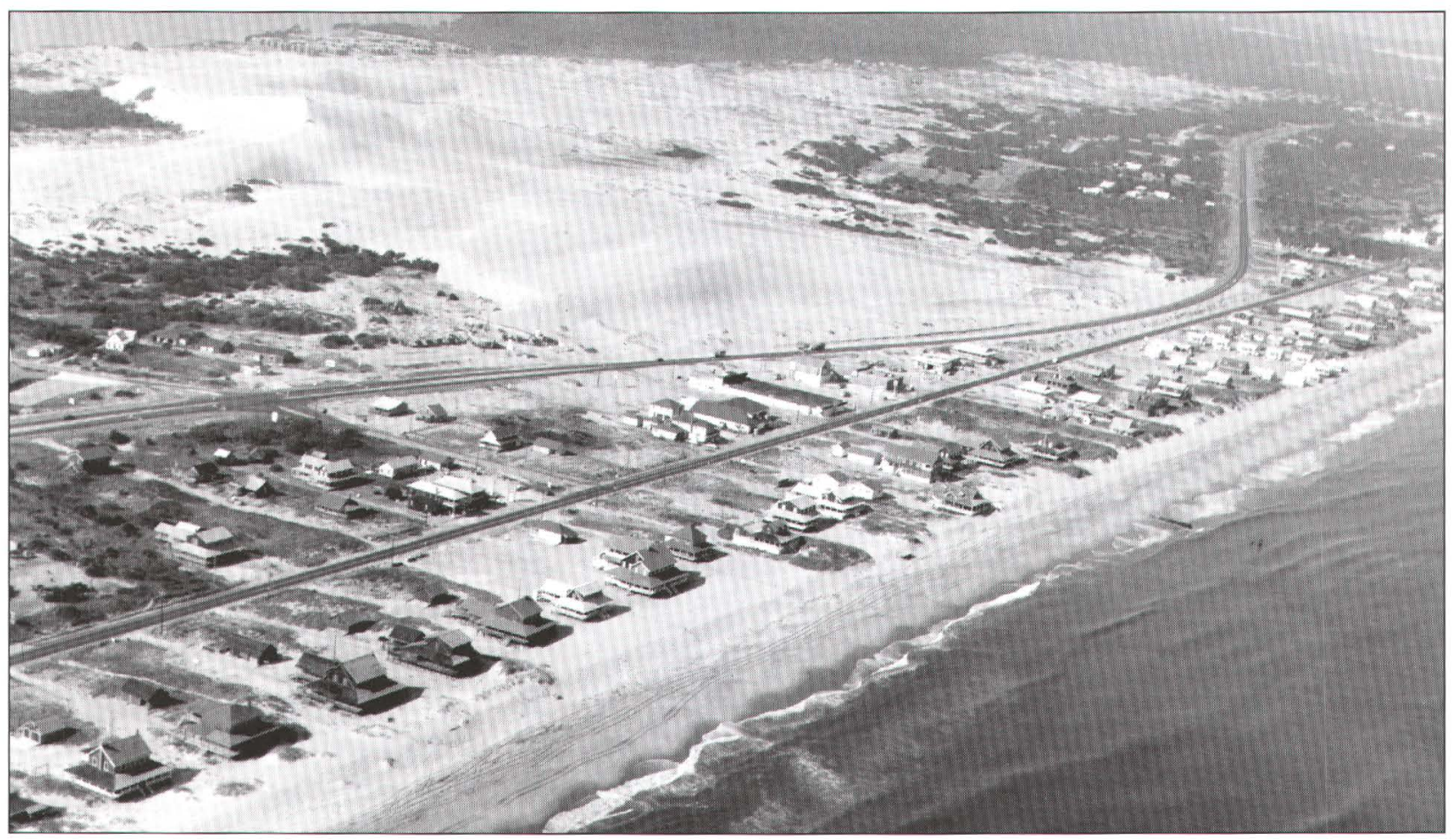

Figure 16. Jockey Ridge near Nags Head, the highest dune field along the Outer Banks. (Source: R. Dolan.)

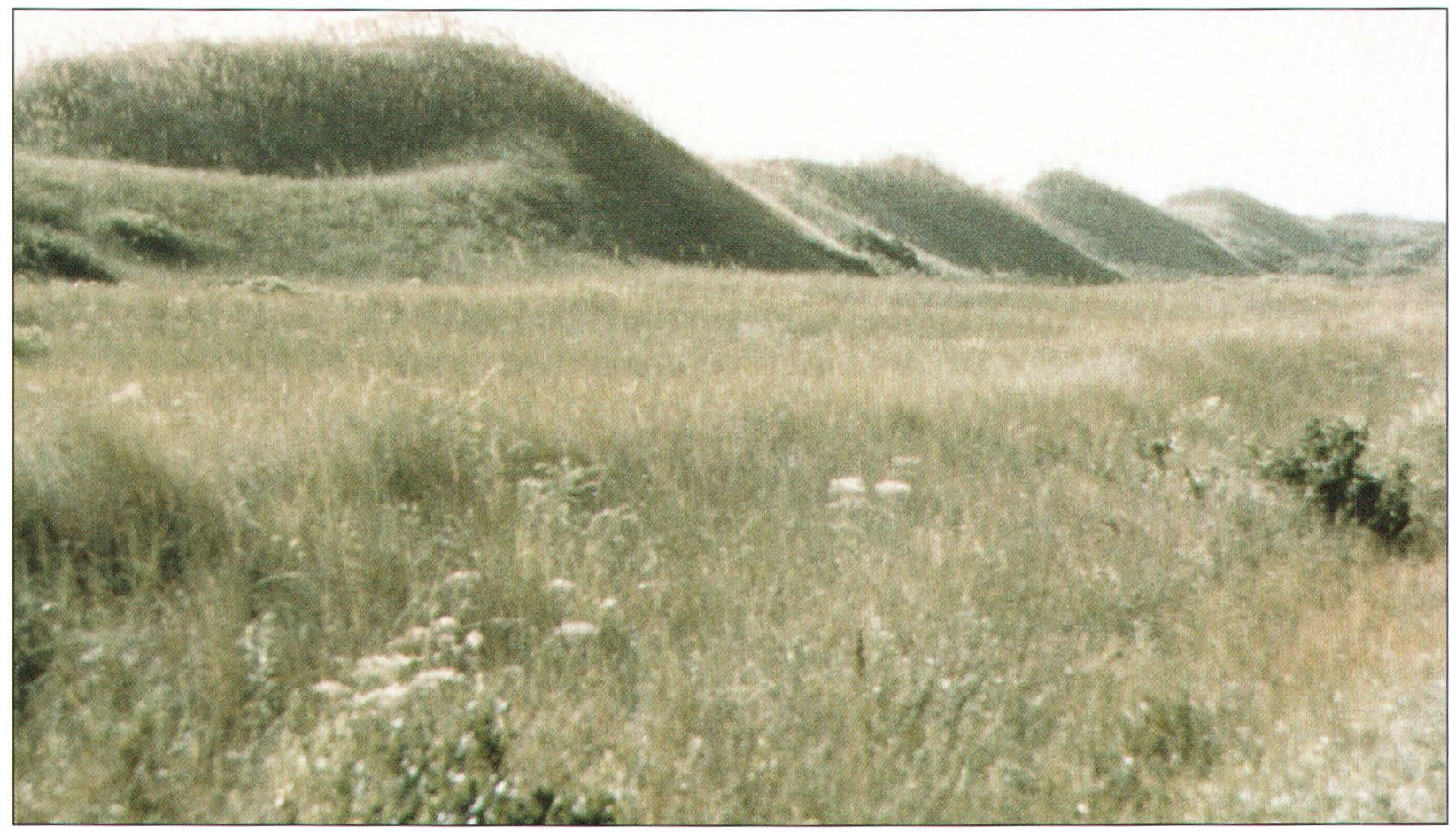

Figure 17. Stabilization of the wide, active sand zone that existed before the 1930's by grass planting (shown) and sand fencing. (Source: R. Dolan.) 


\section{GEOLOGICAL HISTORY OF THE OUTER BANKS}

The processes responsible for the formation of barrier islands have been debated by earth scientists for many years (Shepard, 1962; Hoyt, 1967; Swift, 1968, 1975; Hoyt and Henry, 1967, 1971; Otvos, 1970; Pierce and Colquhoun, 1970; Schwartz, 1971, 1973). The formation of the Outer Banks is believed to have resulted from a combination of spit growth and beach emergence. Accordingly, sediment, deposited as deltas within Pleistocene coastal river systems, was reworked by wave action and transported along the shore. As time passed, the complex elongated landscape of the Outer Banks evolved.

Several stratigraphic studies have indicated that most mid-Atlantic barrier islands are migrating landward (Kraft, 1971; Kraft and others, 1976; Fisher and Simpson, 1979; Moslow and Heron, 1979). Peat deposits and tree stumps, remnants of forest stands which generally occur on the back side of barrier islands, are now being found on open ocean beaches (fig. 18), indicating distinct landward movement (Kraft and others, 1973; Field and others, 1979; Dillon and Oldale, 1978). In addition, overall island recession can be measured from historical maps (fig. 19) and aerial photographs (Shepard and Wanless, 1971; Hayden, Dolan, and Ross, 1979). As indicated earlier, change on sedimentary coasts is a function of three factors: The amount and attributes of sediment within a coastal segment, the magnitude of natural processes, and the stability of sea level. These factors also are related directly to the geological origin of barrier islands.

It generally is accepted that sea level has oscillated several times during the past one-half million years (Donn, Farrand, and Ewing, 1962; Emiliani, 1970). During the warmer interglacial periods, continental ice melted causing the shorelines to advance inland across the Continental Shelf. During

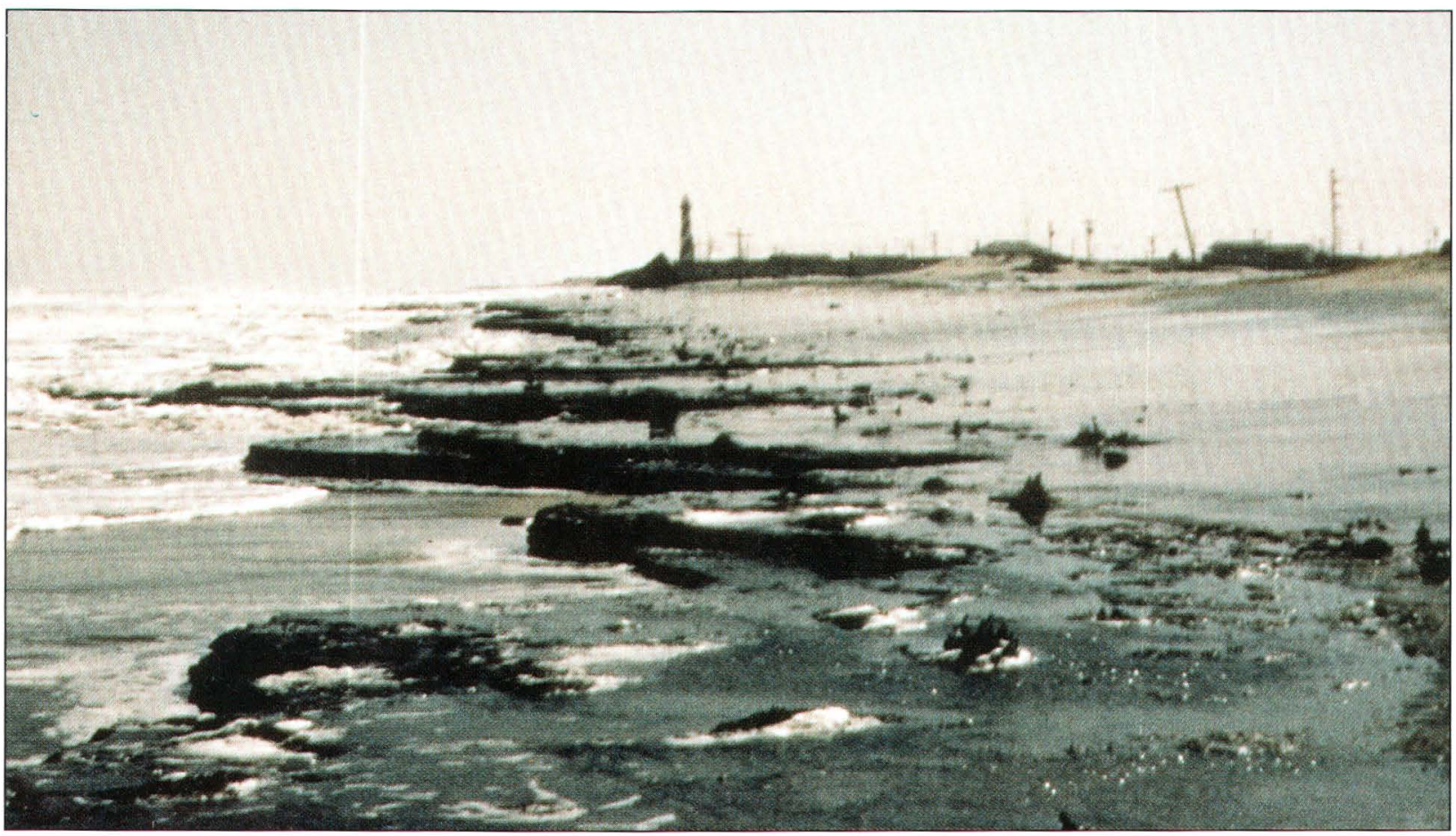

Figure 18. As the barrier islands migrate landward, freshwater peat deposits are uncovered. (Source: R. Dolan.) 


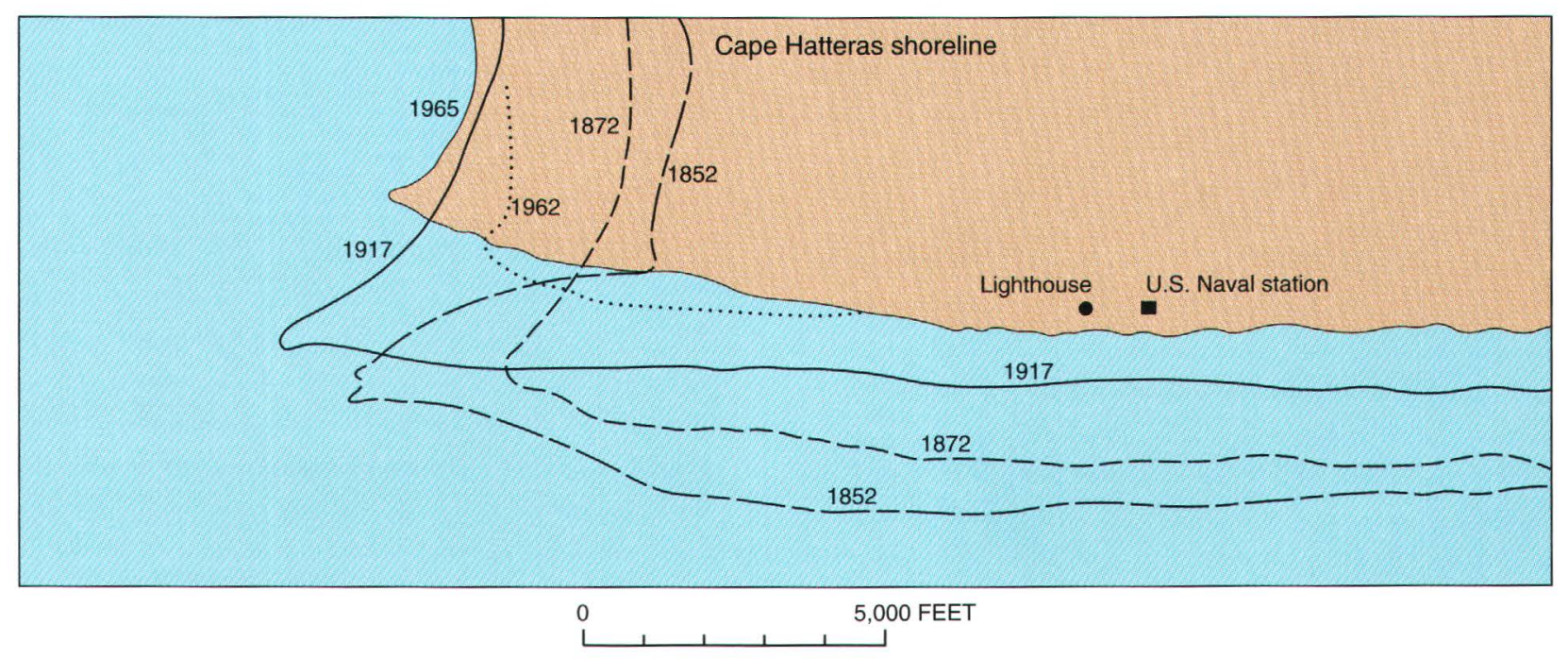

Figure 19. Evidence of shoreline recession is readily available from comparison of old maps and charts. (Source: U.S. Army Corps of Engineers.)

the cooler glacial periods, when water was withdrawn from the seas and stored as glacial ice, the shorelines moved seaward (fig. 20).

When the last period of glaciation, the Wisconsin, ended between 14,000 and 18,000 years ago, sea level was approximately 300 feet lower than it is today, and the shoreline of the North Carolina coast was 50 to 75 miles seaward (fig. 20) of its present position (Emery, 1968). With the change from glacial to interglacial conditions, which marked the transition from Pleistocene to Holocene, the sea level began rising, initiating what is known as the Holocene marine transgression (fig. 21).

As sea level rose and the shoreline moved across the Continental Shelf, large masses of sand in the form of beach deposits were moved with the migrating shore zone (Duane and others, 1972; Field and Duane, 1976; Emery, 1968). In addition, sediment, deposited as deltas within the coastal river systems, was reworked by wave action and moved along the shore (fig. 22). When the rate of sea-level rise slowed about 4,000 years ago, waves, currents, and winds reworked the sand to form the beaches and barrier islands that stretch from New England to Texas. As long as the inshore system contained surplus sediment, the beaches continued to build seaward. At that time, some parts of the Outer Banks may have been wider, perhaps as wide as a mile or more. In narrow areas, inlets breached the islands and later filled in to reform them. Long spits connected the wider, more stable sections, such as the land areas near
Cape Hatteras, Southern Shores, Colington, Nags Head Woods, Avon, Frisco, and Ocracoke, where sequences of beach ridges developed (fig. 23). In this way, long chains of Holocene barrier islands evolved.

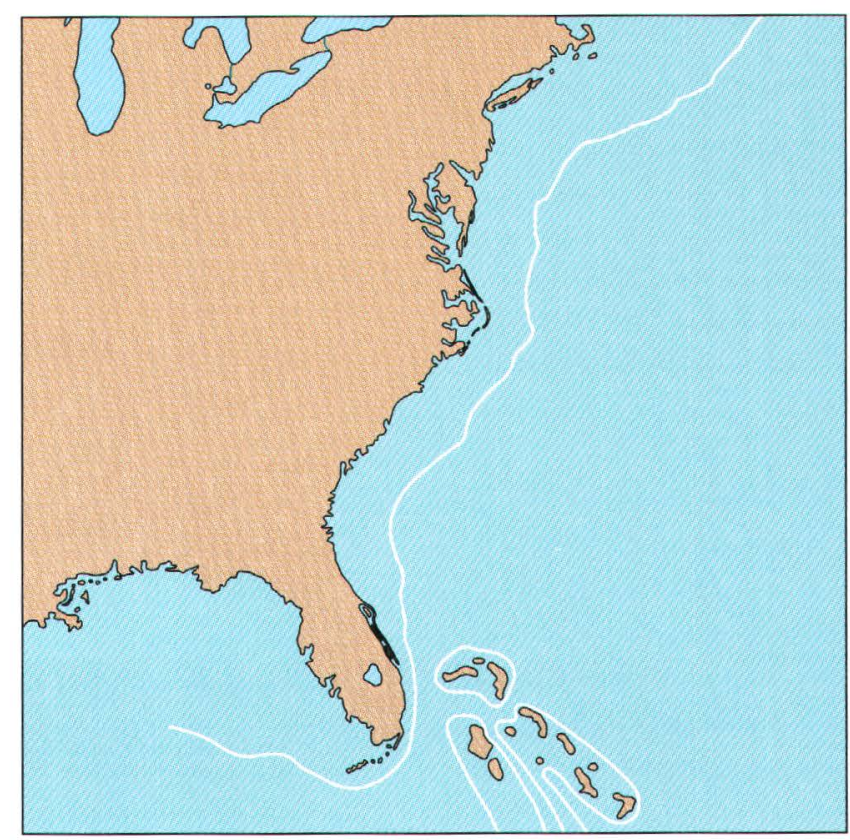

Figure 20. Atlantic coast shoreline 15,000 years ago when sea level was much lower than today. (Source: American Scientist.) 


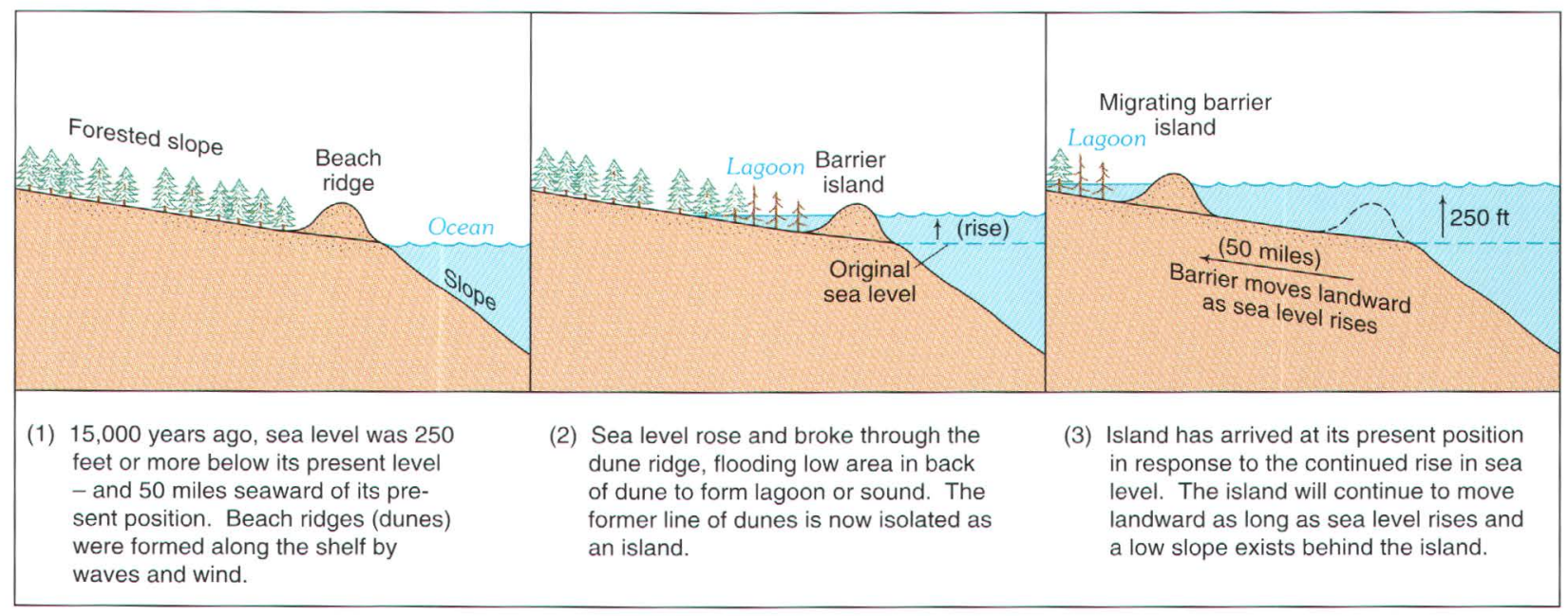

Figure 21. Evolution of the barrier islands. (Source: J. Hoyt.)

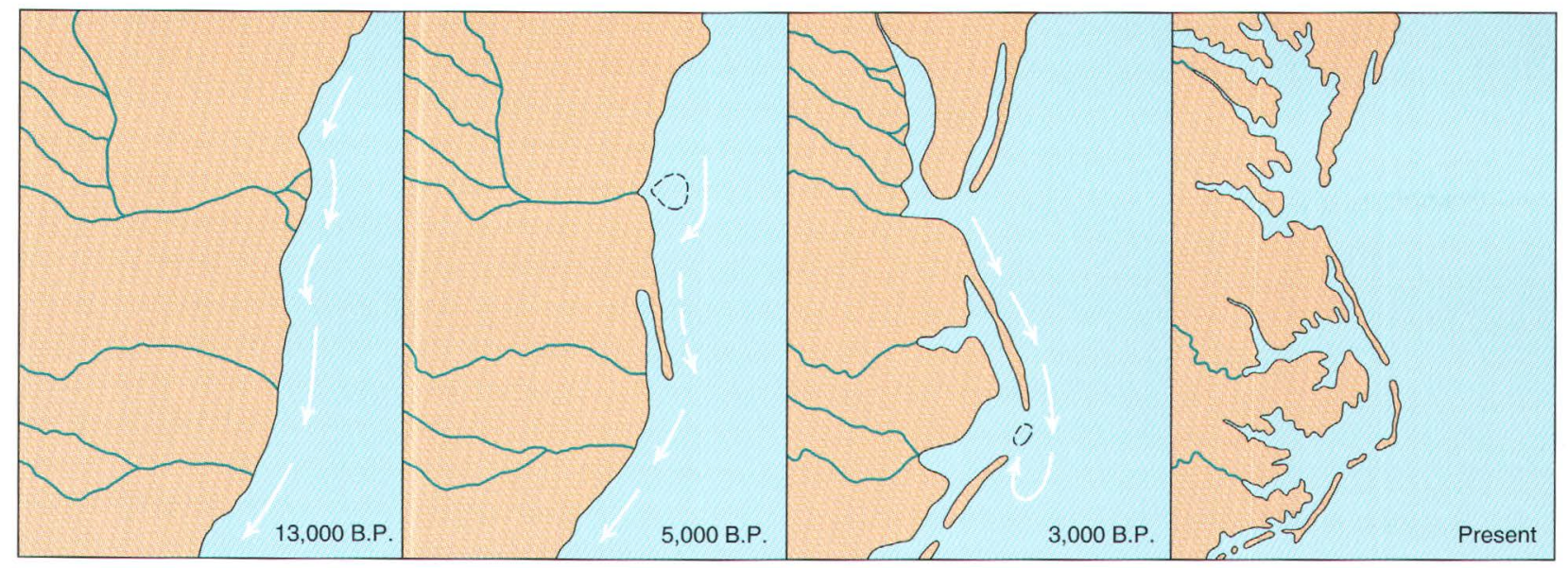

Figure 22. Model for evolution of North Carolina barrier islands. (Source: S. Riggs.) 

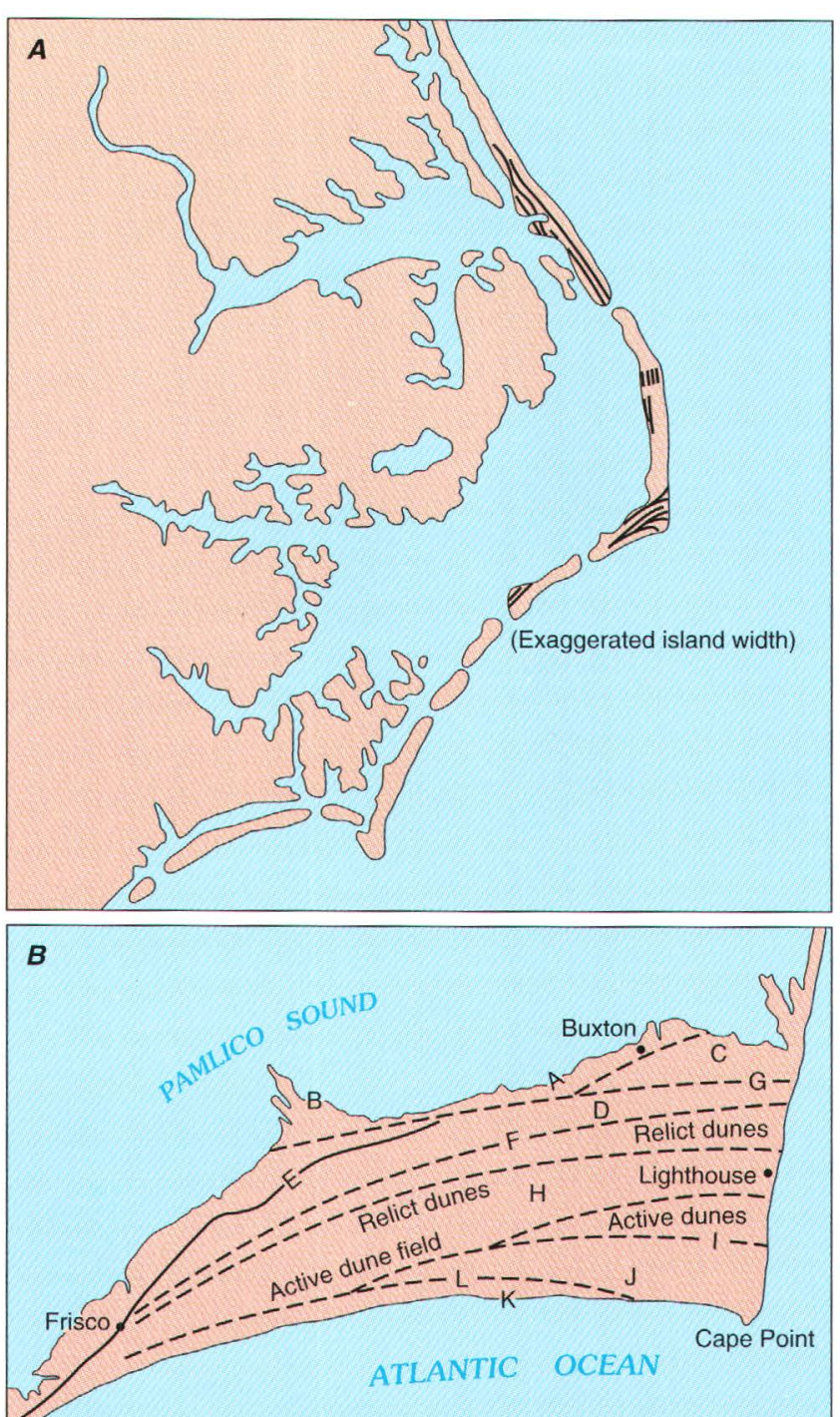

Figure 23. A, Distribution of high barrier dune ridges of early Holocene age, and $B$, the complex pattern of dune ridges at Cape Hatteras. (Source: J. Fisher.)

A detailed plot of Holocene sea-level change reveals a clear pattern (fig. 24) - a long-term trend of sea-level rise. Although this trend may continue for only a short geological time (possibly only a few thousand years), it may continue long enough to have significant effects on coastal development and habitation of the Outer Banks. The estimated effects on North Carolina's shoreline of a continuation of the current rate of sea-level rise for the next 1,000 years is shown on the map in figure 25 .

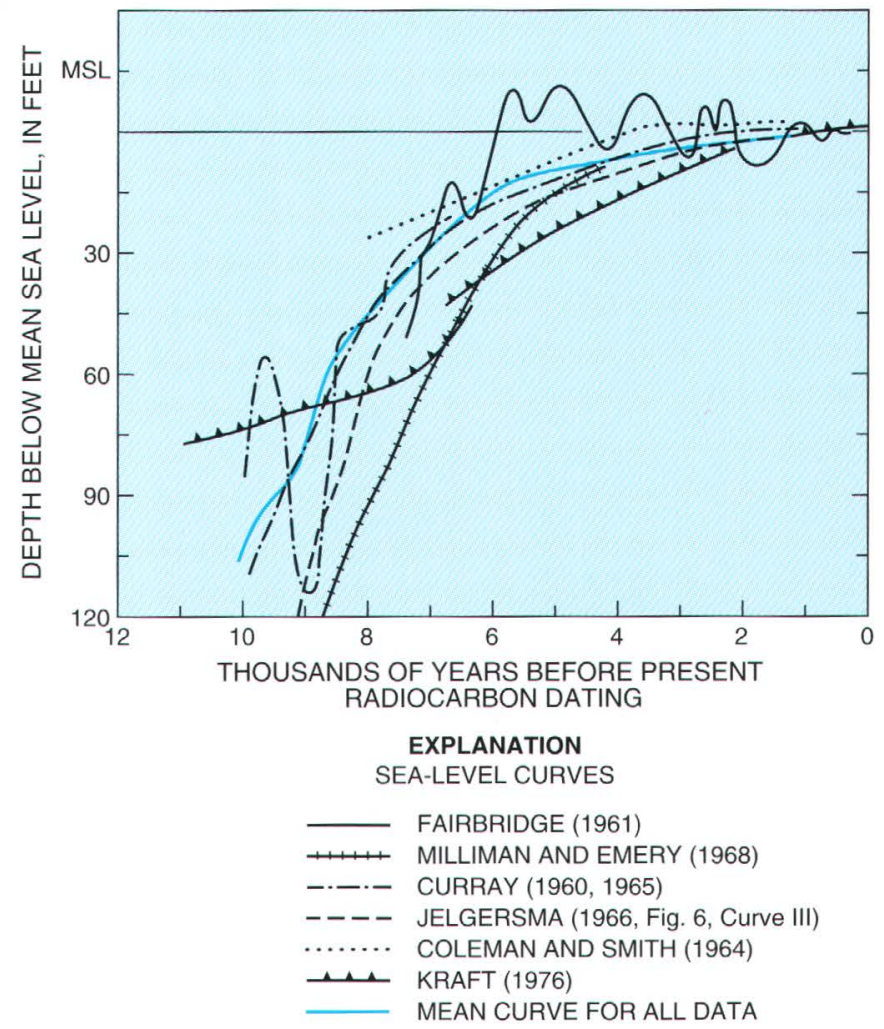

Figure 24. Late Holocene sea-level curve based on radiocarbon dates. (Source: Moslow and Heron, 1978.)

As stated previously, overwash and inlet formation are the most important processes in landward movement of the Outer Banks. During severe storms, the beach zone of seaward dunes is overtopped by high water and waves (fig. 26). As this sediment-laden mass of water spills across the beach and flows toward the bays and sounds on the inland margin of the islands, a layer of sediment is removed from the beach and added to the island's interior. This process transforms the shape and position of the island but conserves much of the sediment mass. 


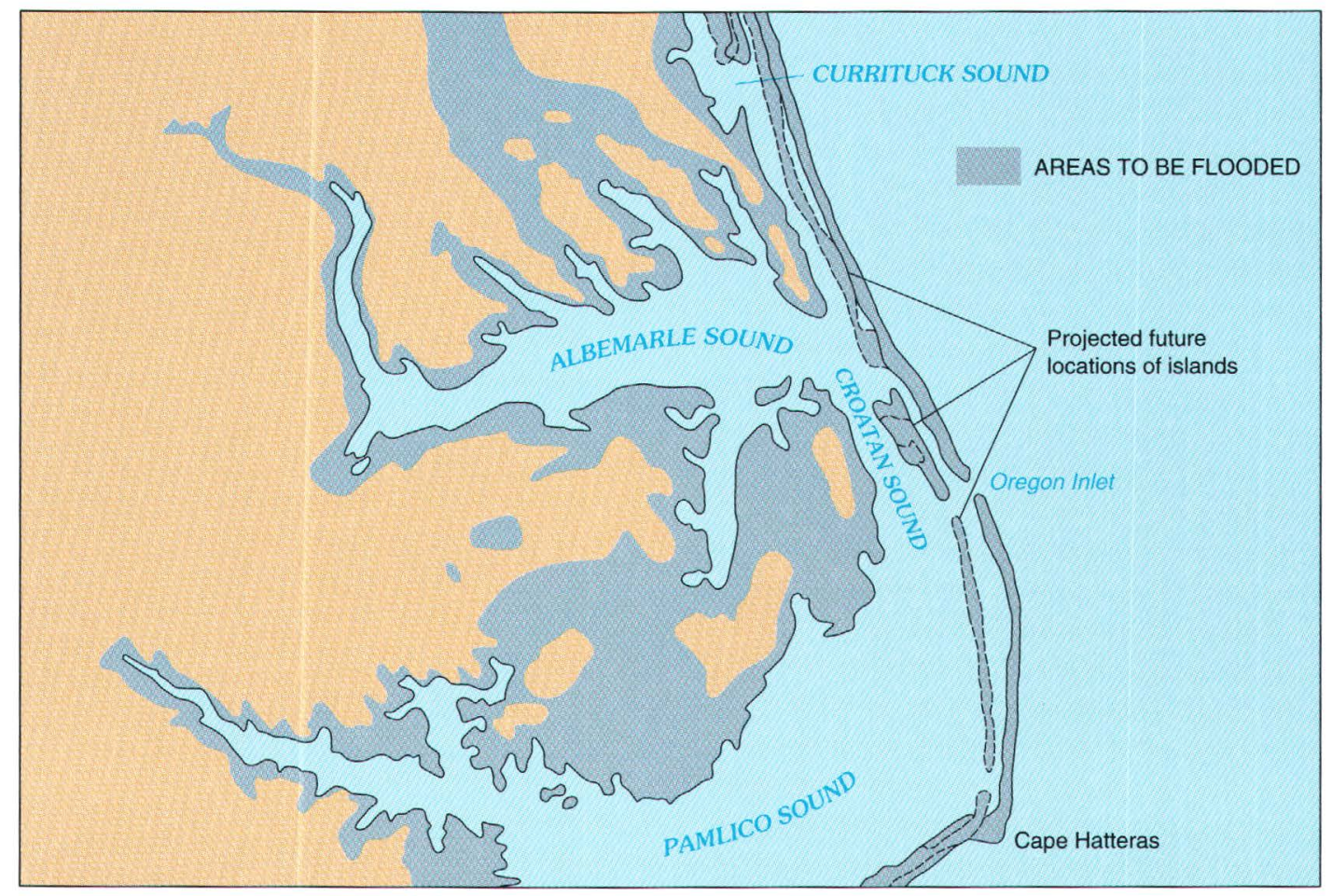

PROJECTED NORTH CAROLINA COASTAL ZONE 2980 AD

Figure 25. Land-water relation along the North Carolina coast for the year 2980, based on the assumption that past trends in sea-level rise will continue for the next 1,000 years. (Source: S. Riggs.)

Figure 26. Pattern of overwash and storm-surge penetration at Nags Head during the March 7, 1962, storm. (Source: R. Dolan.)

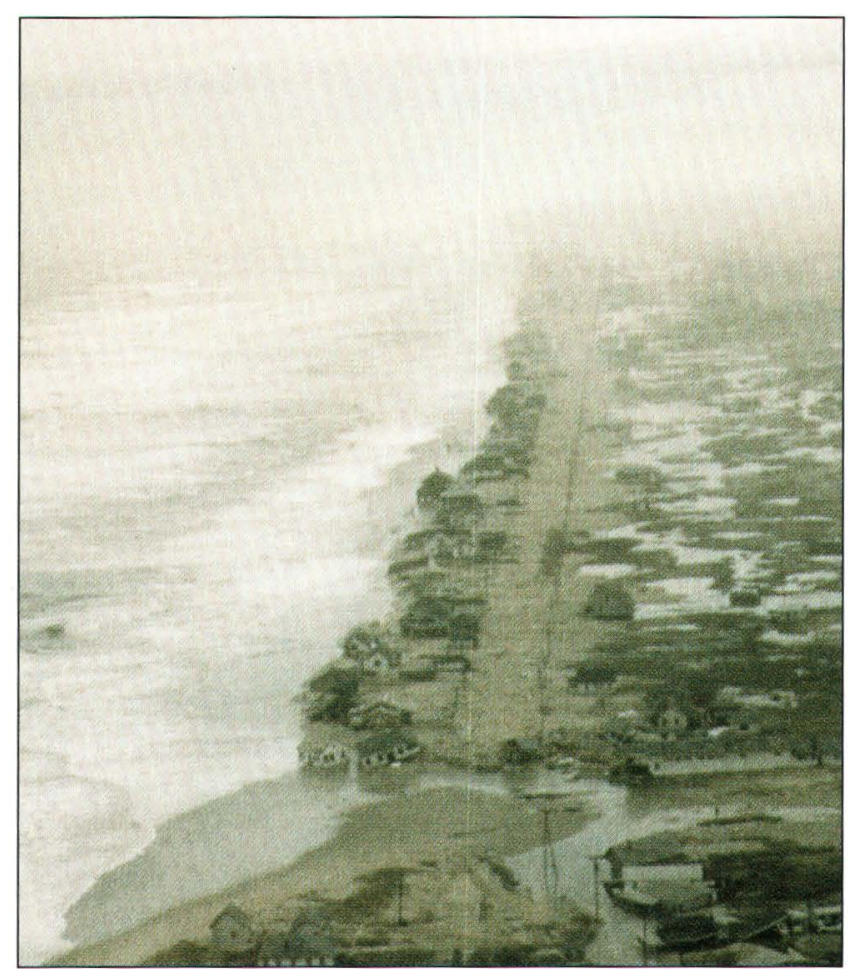


During storms, sand also moves inland through inlets into the interior bays and lagoons. This type of movement is common along the east coast, particularly south of Cape Cod. Temporary inlets are formed during storms when the islands are overwashed and breached, creating openings to the lagoons and bays behind the beaches (fig. 27). Most of these inlets eventually close, unless a major river discharges behind them. Although the inlet is open, however, sand is moved through it and is deposited on the inside

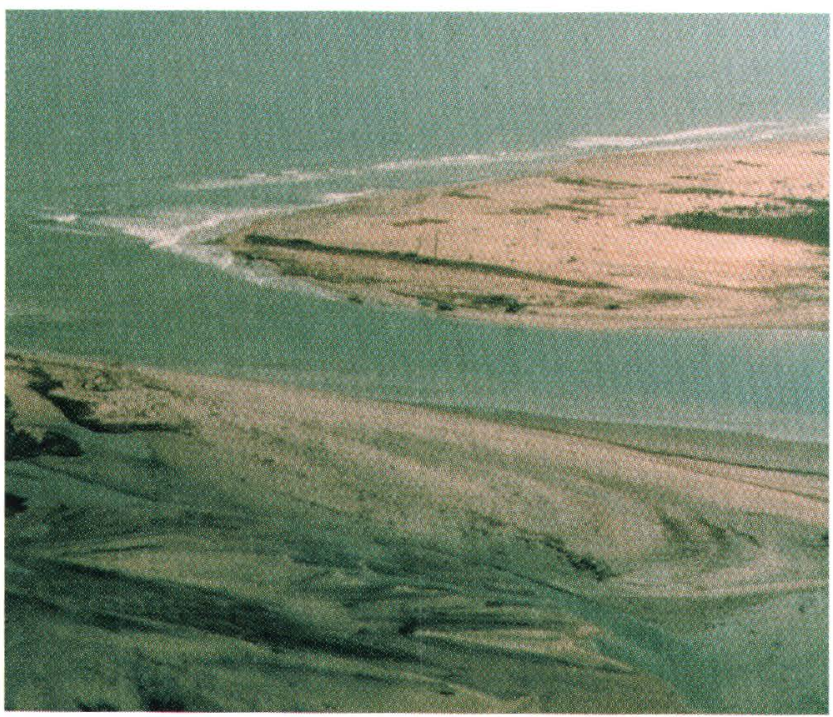

Figure 27. Temporary inlet formed near Cape Hatteras during the March 7, 1962, storm. It was filled in soon after it formed. (Source: R. Dolan.)

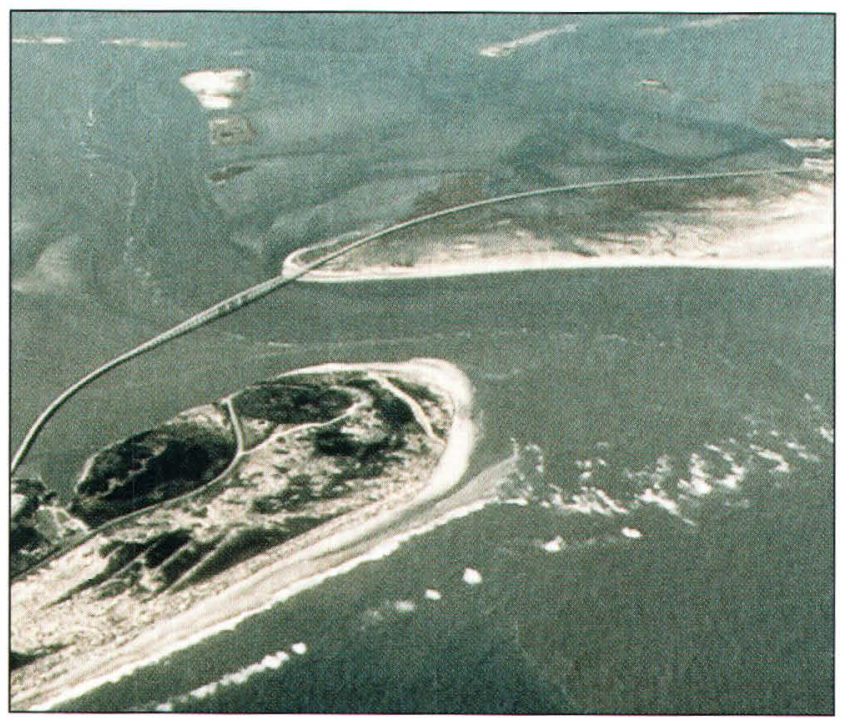

Figure 28. Pattern of sedimentation at Oregon Inlet. (Source: R. Dolan.) of the barrier in large, fan-shaped shoals (Pierce, 1969). Sand also is carried out during ebb tide, and a similar delta may be created in the ocean (fig. 28). The bayside inlet shoals are exposed at low tide and eventually become new substrates for highly productive salt marshes (Godfrey, 1970, 1976). Shoals below low tide support underwater grass beds. Although overwash fans crossing the islands also create fringes of marsh substrate (fig. 29), the inlet deposits create the most extensive marshes that project into the sounds and bays (fig. 13) behind the barrier islands (Hayden and Dolan, 1979).

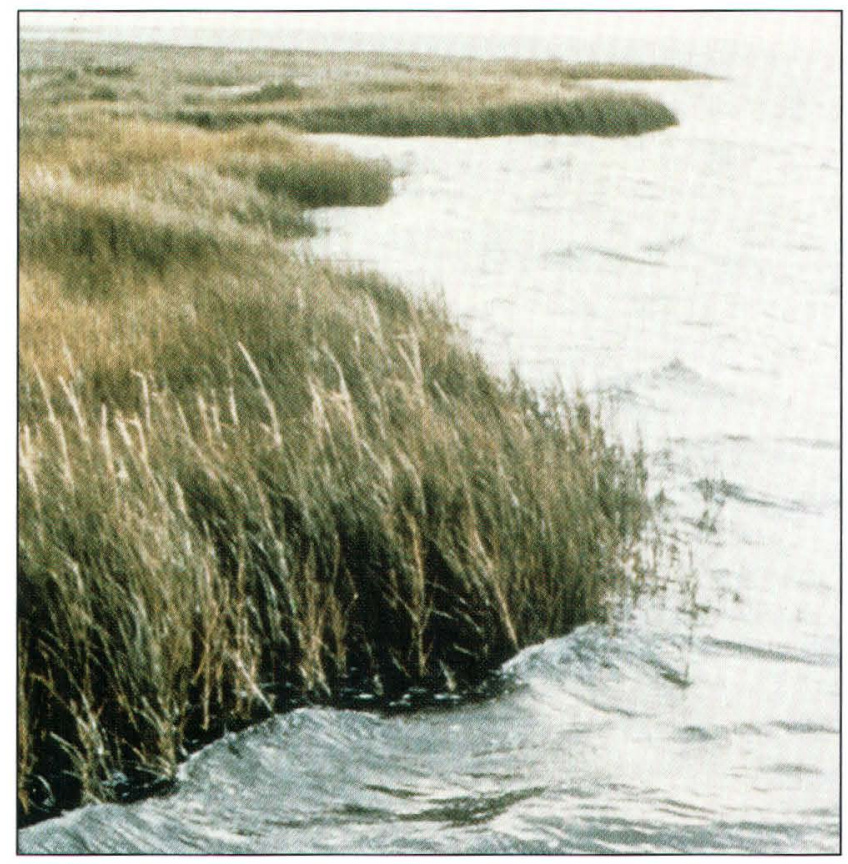

Figure 29. Fringe of salt marsh on the sound side of Core Banks. (Source: P. Godfrey.)

Although overwash and inlet formation are dominant processes of change, Godfrey, Leatherman, and Zaremba (1979) and Fisher (1968) have pointed out that regional differences are significant. In the Northeast, for example, overwash occurs less frequently, and large dunes and cliffs have been formed by sediment eroded from glacial deposits. Along the Outer Banks, where tide ranges are lower and the sediment supply smaller, overwash is more common. 


\section{Shoreline Configuration}

Even a cursory inspection of photographs of the Atlantic coast obtained from aircraft or spacecraft reveals large crescent-shaped configurations (fig. 30). Some of these crescentic patterns are the result of variations in the rates of shoreline change. Along the Virginia barrier islands, for example, the rate of shoreline erosion varies systematically with the configuration of the shoreline (Dolan, Hayden, and Jones, 1979). Erosion rates are greatest where the orientation of the shoreline is near $28^{\circ}$ east of north;
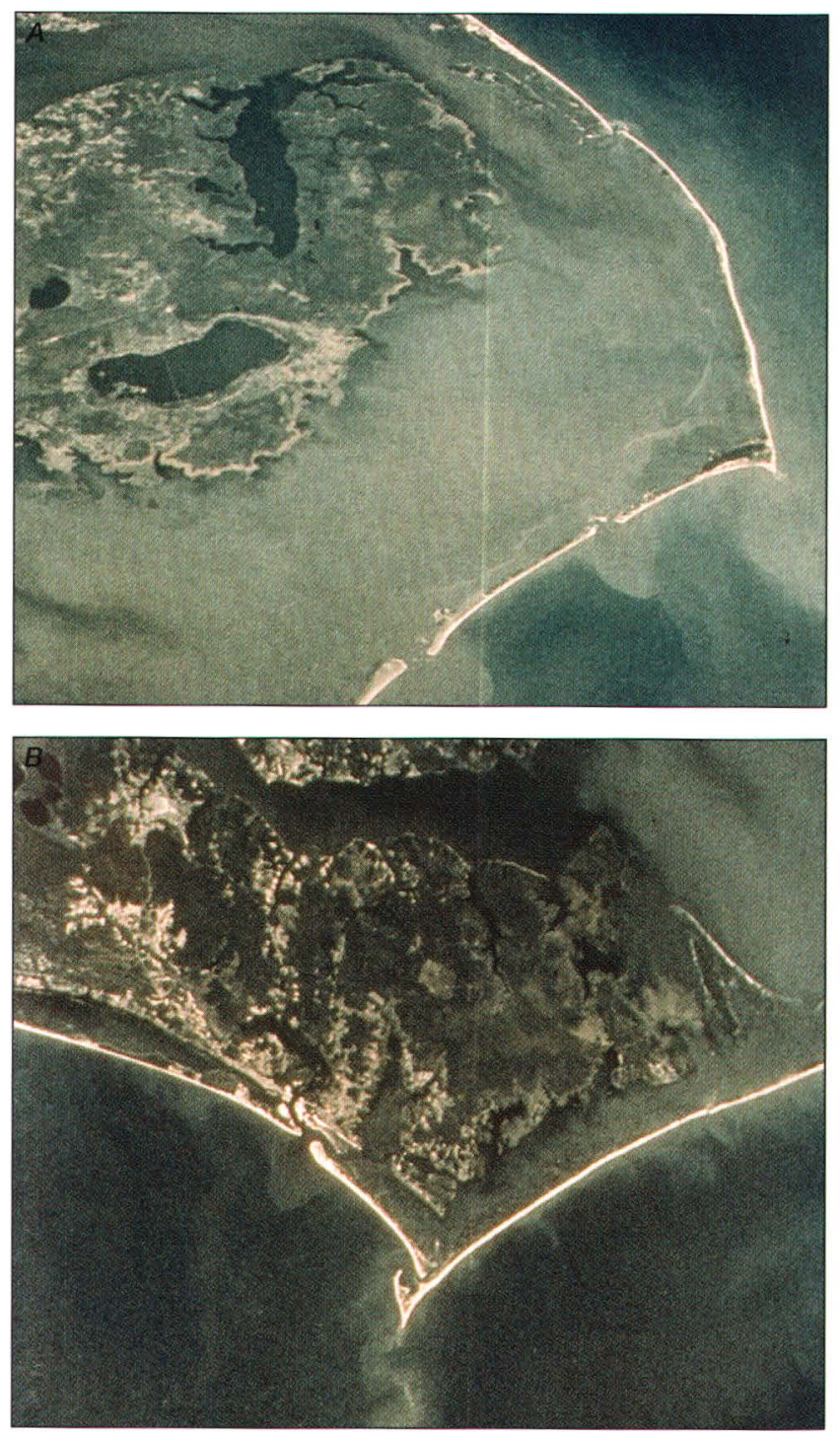

Figure 30. Large crescentic landforms. Smaller features also are evident in these two space photographs. A, Cape Hatteras. B, Cape Lookout. (Source: National Aeronautics and Space Administration.) that is, where the long axis of the island runs northeast-southwest. Erosion is less at smaller and larger angles. This difference in erosion rates results in a series of crescent-shaped landforms. At places, the shoreline is concave and, at others, convex, forming what are sometimes called false capes.

Along the Atlantic coast, the largest crescentic landforms are the broad arcs of the North Carolina coast that span distances of approximately 60 miles. Smaller crescentic forms occur within these large arcs, including beach cusps (30-100 feet), giant beach cusps (330-650 feet), and some larger forms (a mile or more long) (Dolan, Hayden, and Vincent, 1974).

Inshore bars and troughs also may assume crescentic and rhythmic configurations in response to sea states, tides, and sea level (Sonu, 1973). Smaller forms appear, disappear, and may migrate along the shoreline, but large ones establish the spatial distribution of shoreline erosion and storm overwash (fig. 31) (Dolan, 1971).

The pattern of storm-surge deposits, or overwash fans, along the Outer Banks after the Ash Wednesday storm of 1962 is shown in figure 32. Although overwash occurred all along the Outer Banks, the distance the sand penetrated inland varies markedly from place to place. A similar pattern is evident on most barrier islands. Analysis of the overwash pattern and the 40-year averages of shoreline positions suggests that, along the coast, periodicities exist for the long-term average shoreline erosion and the penetration of storm surge during a single storm. These patterns indicate the places where erosion and storm damage occur (fig. 32). The natural configuration of sedimentary coastlines, as determined by shore-zone processes, is periodic and crescentic rather than straight. The larger wave lengths (more than 8-10 miles) are less apparent because their curvature is smaller; thus, their relative amplitude is lower. In analyzing long sections of the coast, their absolute amplitude is greater than the smaller crescentic features. However, the larger crescentic forms are difficult to recognize during a stroll along the beach. They are most visible in photographs taken from high altitudes. 


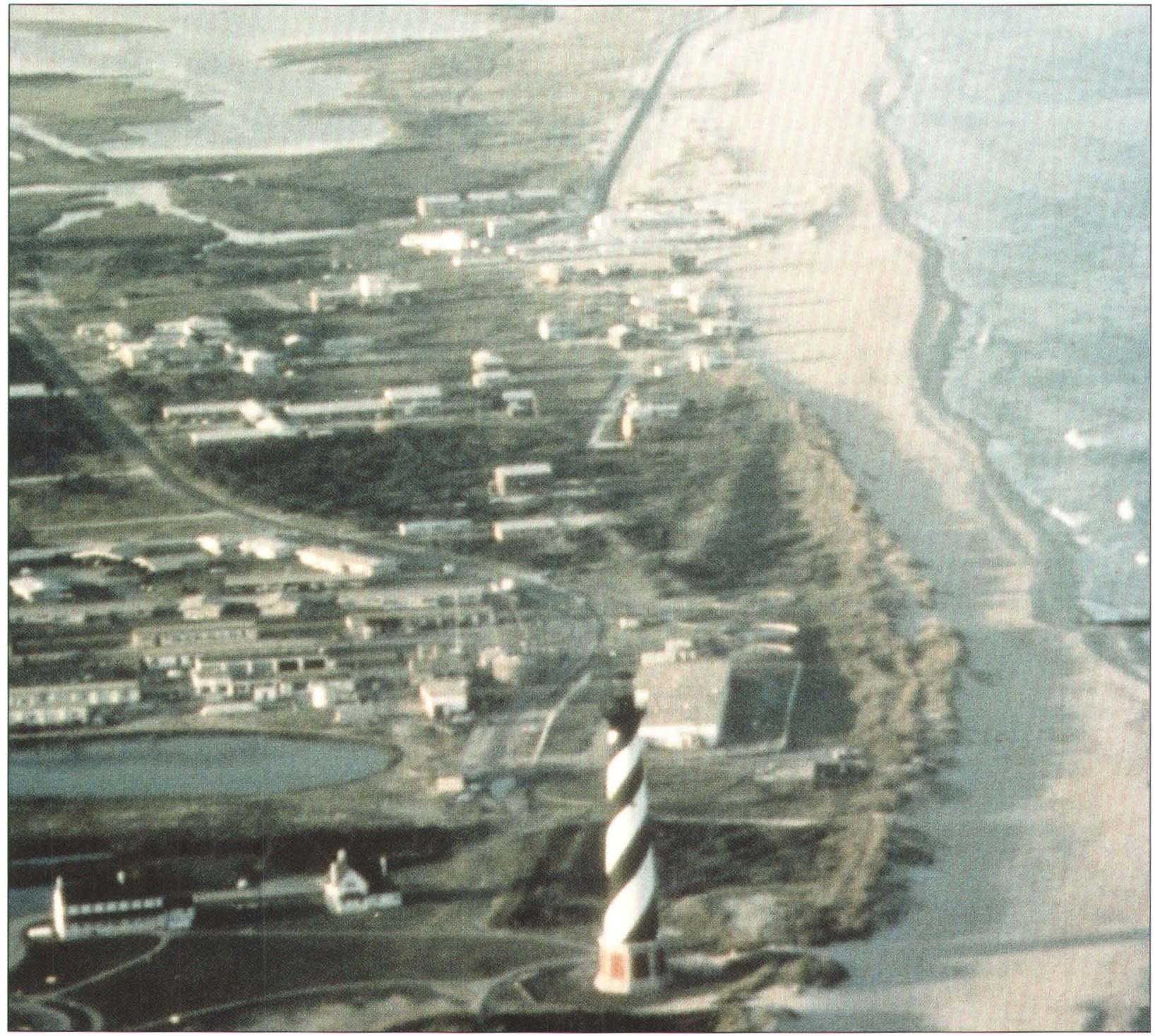

Figure 31. Small crescentic landforms along the Outer Banks. (Source: R. Dolan.) 


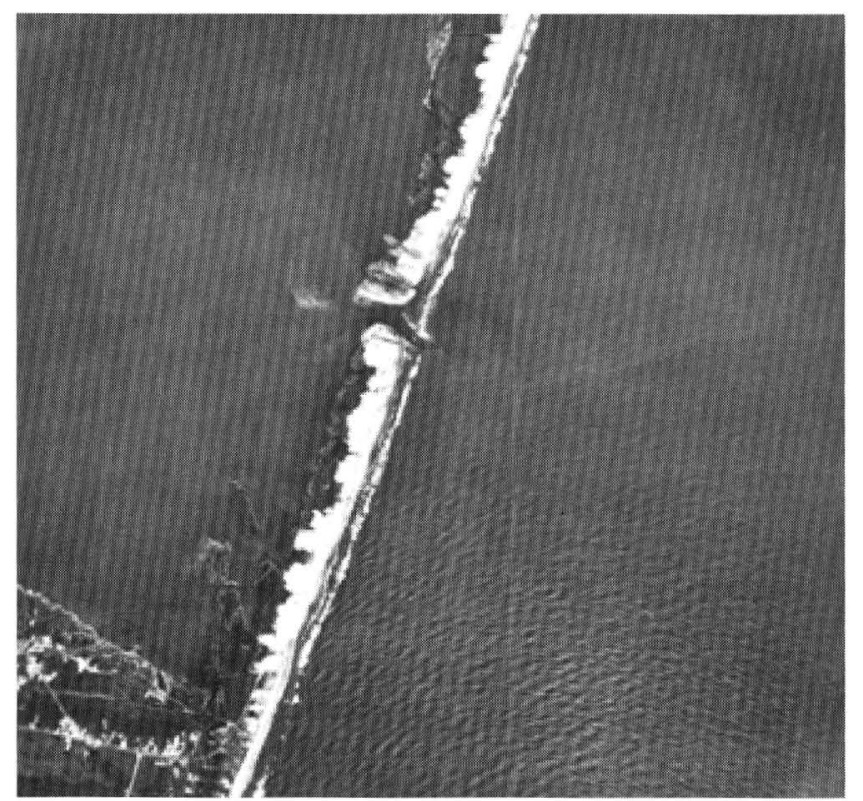

Figure 32. Pattern of storm-surge penetration along Hatteras Island, 1962. (Source: U.S. Army.)

In the 1950's, some homes on the Outer Banks were constructed on concrete slabs. Some are still there today, having weathered hundreds of storms, including the great Ash Wednesday northeaster, but other houses nearby have long since disappeared. Is the vulnerability of some places along the coast simply a matter of chance or is there a pattern to the hazards? Recent research suggests that even at site-level scales (hundreds of feet), shore-zone processes and shorezone landforms assume systematic patterns along and across the coast (Dolan and Hayden, 1980). This conclusion is a departure from the more common conception that coastal change and coastal hazards are random or happenstance events.

If storm hazards along the coast are distributed systematically, then they should be predictable. The problem is that detailed historical information for establishing past patterns is not always available. However, sections of sedimentary coasts that have experienced storm damage and serious erosion in the past are likely to experience more of the same in the future (fig. 33). Thus, a natural "template of change" exists that is governed by the coastal configuration.

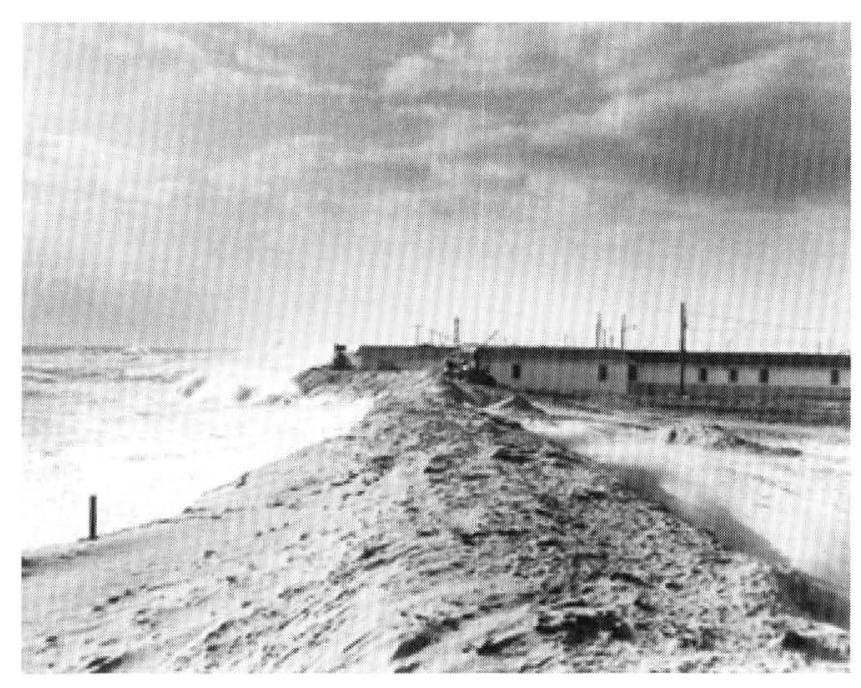

Figure 33. Serious losses of property near Cape Hatteras caused by shoreline recession and storm tides. (Source: R. Dolan.)

\section{HISTORY AND DEVELOPMENT}

The North Carolina barrier islands were discovered by European explorers in the 16th century, but they were not permanently settled until the mid-17th century. From the beginning, proximity to the ocean and the mainland has been important to those living on the Outer Banks. The natural processes that formed these islands, especially the openings and closings of inlets, have hindered trade and commerce and have caused major redistributions of the populations for the past 400 years.

In 1584, Sir Walter Raleigh sent two vessels across the Atlantic to search for suitable sites for settlements in the New World. Within a year, a settlement was established on the Outer Banks at the northern end of Roanoke Island (fig. 34). This settlement was, however, short lived. A supply ship, returning from England in 1590, found no trace of the colonists. To this day, the disappearance of the "Lost Colony" has remained a historical puzzle (Dolan and Bosserman, 1972).

The first permanent settlement on the Outer Banks was located in 1663 on present-day Colington Island (fig. 34), where the English colonists settled within the dune fields on the sound side of the island. The dunes provided timber, fuel, freshwater, and protection from strong winds and storm tides. Although the most profitable occupation at the time 


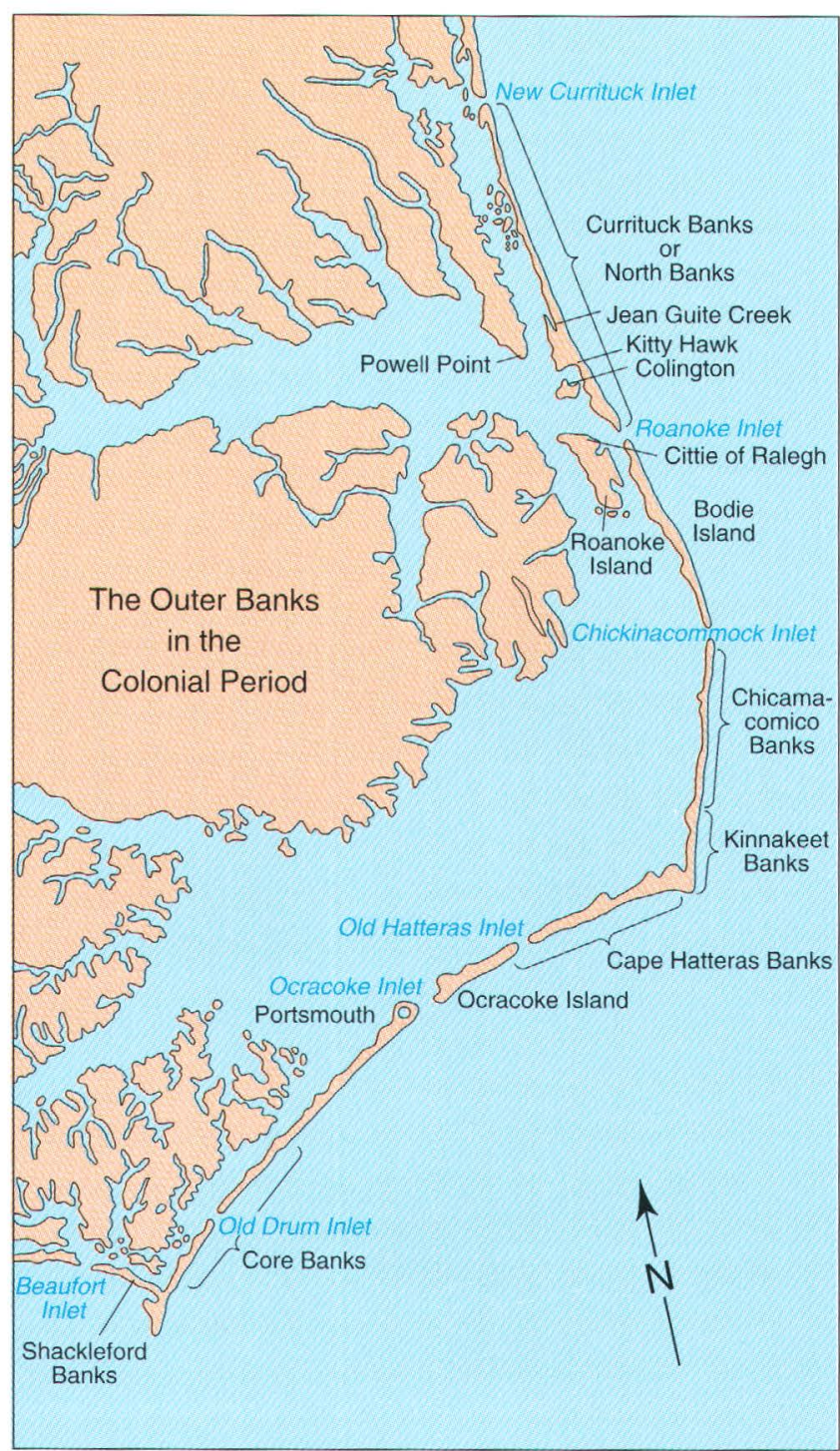

Figure 34. Location of early settlements on the Outer Banks. (Source: National Park Service.)

was the sale of oil extracted from whales washed up on the shore, the extensive unfenced grazing land soon led to the development of a livestock industry (Stick, 1958).

Before 1700 , most settlements were located between Roanoke and Currituck Inlets. As Roanoke Inlet began to shoal and eventually close, however, maritime traffic was routed 75 miles south to Ocracoke Inlet. By 1750, hundreds of ships were using Ocracoke Inlet as a trade route. Port Bath, the official port of entry in 1715 , became the largest community on the Outer Banks. The town of Portsmouth, established as a transshipment point for goods bound for the interior of the Carolina colony, grew rapidly.
A few wealthy businessmen controlled the land on the Outer Banks by the 1700's. By the end of the Revolutionary War, however, many of the largest holdings were subdivided into small plots, and new construction began.

Shipbuilding and lumber industries were among the most successful trades in the early 1800's (Stick, 1958). Forests of live oak, pine, and cedar were depleted rapidly. Livestock grazed on the open dunes. The new sense of nationalism brought on by independence not only created a desire to acquire title to the land, but it also gave "bankers" (farmers) the impetus to improve transportation routes and construct lighthouses to make ocean travel safer.

Shipping lanes off the North Carolina coast always have been among the most treacherous in the world. The northward-flowing Gulf Stream and southbound drift along the Virginia coast make travel in sailing vessels faster but also force ships to navigate dangerously close to the shore (Roush, 1968). Before the construction of lighthouses, hundreds of vessels were lost during storms when they were driven either onto the shoals or the coast (fig. 35). The area around Cape Hatteras known as Diamond Shoals also came to be known as the "Graveyard of the Atlantic."

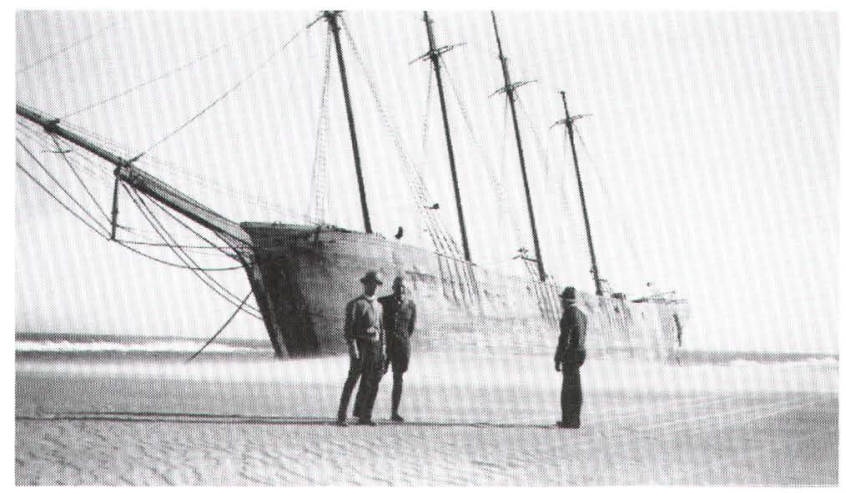

Figure 35. One of the more than 1,000 ships that wrecked on the Outer Banks during the 1800's. (Source: National Park Service.)

The first lighthouse on the Outer Banks was built on an island in Ocracoke Inlet. The original foundation of the Cape Hatteras Lighthouse, built in 1802, can still be seen (Stick, 1958). The present Cape Hatteras Lighthouse was completed in 1870. The Ocracoke Lighthouse, built in 1823, is the oldest still standing on the Outer Banks. On Bodie Island, three lighthouses have been constructed. The last, built in 1872 , is still in use today. The Cape Lookout 


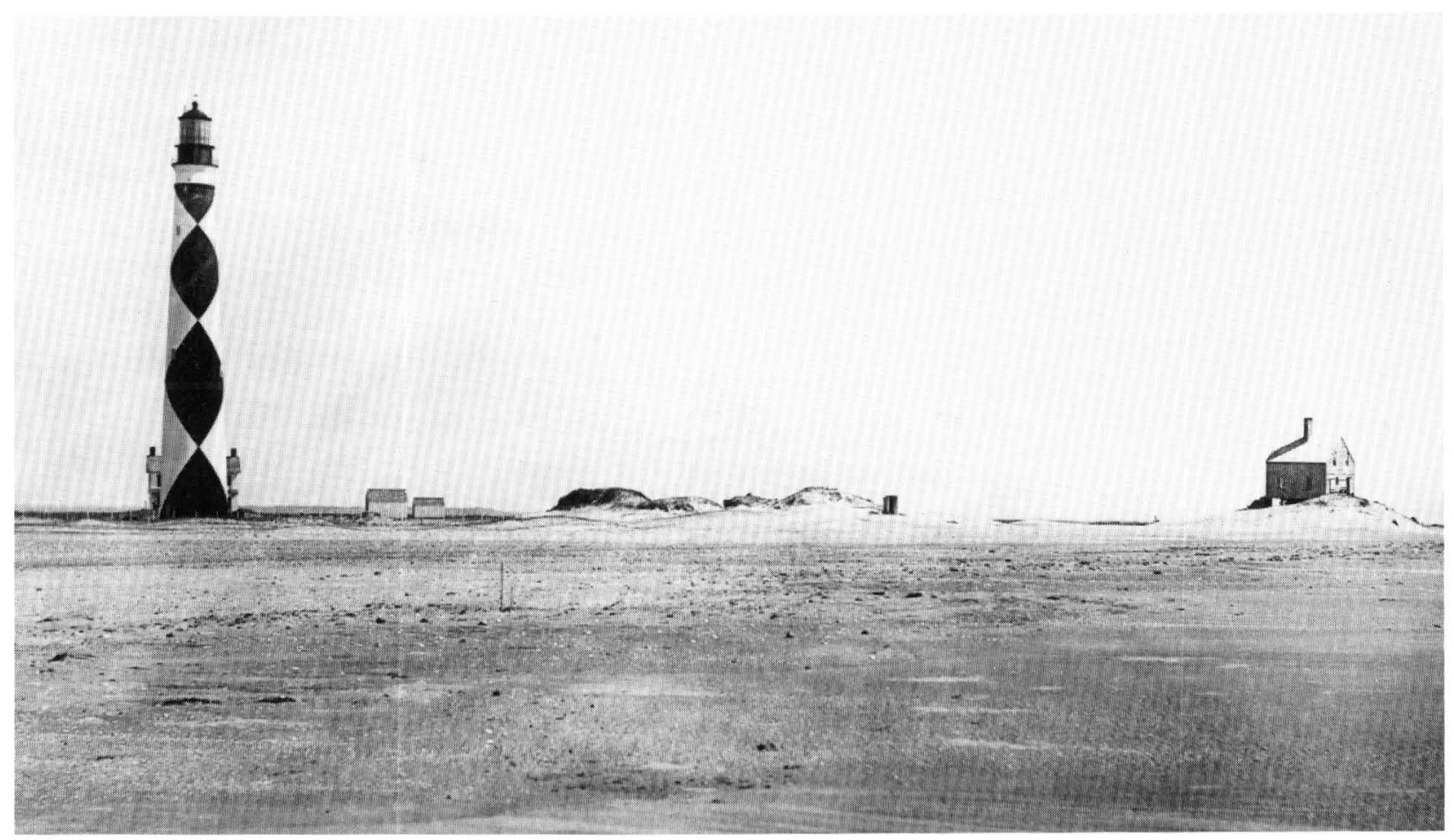

Figure 36. The Cape Lookout lighthouse in the 1930's. Note the absence of vegetation during this period. (Source: National Archives.)

Lighthouse, originally built around 1812, was vandalized during the Civil War, and the present structure was completed in 1873 (fig. 36). The last Outer Banks lighthouse was constructed at Corolla in 1875 (Holland, 1968).

Lifesaving stations, built 7 miles apart, appeared on the Outer Banks in the late 1800's. Five Coast Guard stations are still active on the Outer Banks today: Oregon Inlet, Cape Hatteras, Hatteras Inlet, Ocracoke, and Cape Lookout.

With the final closing of Roanoke Inlet in 1811, it became apparent that the same thing could happen to Ocracoke Inlet. Therefore, in 1830, the first attempt was made to alter natural processes along the Outer Banks. A special dredging machine was used in the inlet to deepen and widen the shipping channel. Sixty feet long and propelled by steam-driven paddle wheels, the dredge was equipped with buckets on a conveyor belt that scooped sand from the channel bottom (fig. 37). For 7 years, work continued on Ocracoke's main channel until engineers concluded it was filling up as fast as it could be dredged (Stick, 1958).

When Currituck Inlet closed in 1828, Ocracoke was the only navigable inlet north of Cape Lookout. In 1846 , a storm breached the Outer Banks in two places, forming what are today Oregon and Hatteras Inlets (Pilkey, Neil, and Pilkey, 1978). Within 20 years, use of Ocracoke Inlet and the town of Portsmouth decreased radically, and Hatteras Inlet surpassed Ocracoke as the most traveled inlet on the North Carolina coast.

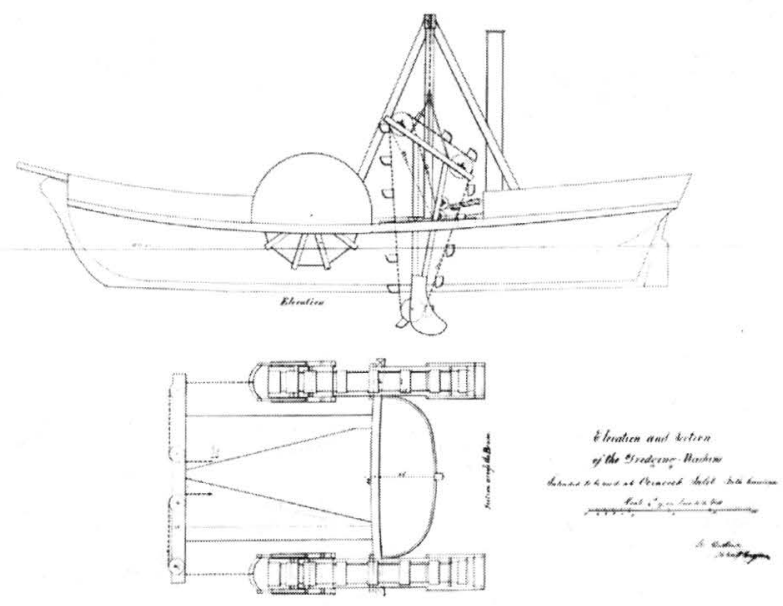

Figure 37. Original drawing of the first dredge (1830's) used to maintain the inlets on the Outer Banks. (Source: National Archives.) 
Vacationers were first reported on these barrier islands as early as 1750 (Stick, 1958). The first indication that the Outer Banks would someday develop into a resort area occurred in 1838 when the first hotel, capable of accommodating 200 guests, was constructed at Nags Head. The hotel and many cottages were built on the sound side because, like the first colonists, the summer residents were aware of the potential hazards of erosion and severe storm tides. Nags Head became known as a favorite "watering place" where wealthy mainland North Carolinians could escape the heat and fevers of malaria so rampant at that time (Stick, 1958).

Three significant changes occurred on the Outer Banks at the end of the Civil War. The first, resulting from the opening of Oregon and Hatteras Inlets in 1846 , was the steady withdrawal of shipping traffic away from Ocracoke Inlet. By 1867, the town of Portsmouth was on a rapid decline. The population of that settlement had dwindled to 18 people in 1955 , and, at present, no permanent residents live there, although numerous buildings remain intact. Further north, however, summer residents were returning to Nags Head. The second change, then, was a new hotel built to replace the original Nags Head Hotel (figs. 38, 39), which had been burned to keep Union forces from using it as a base of operations. And third, some summer residents began building cottages on the ocean side of the island (Pilkey, Neil, and Pilkey, 1978).

By the Great Depression, little industry existed on the Outer Banks. Nothing had been done over the years to improve the strain of cattle, and shipping traffic had been reduced to small, private boats. Improved navigation aids decreased the number of shipwrecks (Stick 1958). Construction of bridges and paved roads in the 1920's and 1930's, however, significantly increased the number of summer visitors. Unlike their early predecessors, those that could afford it preferred to buy land on the ocean side. The location of the first paved road near the shoreline had much to do with this pattern of land development. Because land values were low and household utilities minimal, little concern was given to building houses close to the beach. During periods of severe erosion, residents could move their cottages back to safer positions (Outlaw, 1956).
NORTH CAROLINA SEA BATEING Nag's Head Hotel.

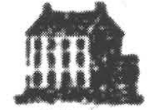

VTIIIS axtensive establishment, recently impros. ed, will be opened for the reception of Visit. nrs, superintended by the Junior Partner, A.J. Batsan, on the lat day of July. The Hotel sitw uatod in view of the Ocean, presents a magnificent prokpect. The great benests resulting frum Sea Bathing and the sea brape, are becoming more known and appreciated daily. No place can be more healthy or posess a finer climate than Nag's

Head. The Bathing is unsurpassed in the Lnited State. We bave engoged a good Band of Music, our Ball Room is very spacious and will be openod every evening. Active and efficient assistants have been engaged, and no exertions will be spared to render it in all respects an agreesble and interesting resort. A Rail Road will be comple. ted early in July from the Hotel to the Ocesn. that persons preferring a ride to walking may be acconimodated.

The steamer Schultz will make s trip every Saturday from Franklin Depot, $V_{\text {a. }}$ to Nags Head, commencing July $12 \mathrm{th}$, immediately after the arrival of the Cars from Norfolk, and returning leave Nags Hend Sunday evening, at 5 o'clock. Pns. agge from Franklin \$3, Riddick's Wharf, Winton. \&c, $\$ 250$, Edenton to Nags' Head $\$ 2$. Meals extra. The Schultu will make several Excursious to Nags' Head through the season, due notice of which will be given. The Pnoket achr. Sarah Porter, Capt. Walker, will make two trips from Edenton, (N. C., ) to Nag's Head each week through the season, leaving Edenton Tuesday and Friday, at 8 o'clock, A M. The Packet schr. A Riddick, Capt. Dunbar, will make three tripench weck through the season. from Elizabeth City ( $\mathrm{N}, \mathrm{C} .4$ ) to Nag's Head, leaving Kizabeth City immediately after the arrival of the stage Coach from Norfolk, Va. Passage on each Packet $\$ 1$. meals extra. Board per day nt the Hotel $\$ 150$. By the week at the rate of 8125 . By the two weeks at the rate of $\$ 1$. By the month at the rate of 75 cents per day. Children and Servants lalf price. The patronage of the pullic is rery respectfully solicited.

June $11.1851-38.2 \mathrm{~m}$. RIDDICK \& BATEMAX

Figure 38. Advertisement for Nags Head Hotel in 1851. (Source: State Archives of North Carolina.) 


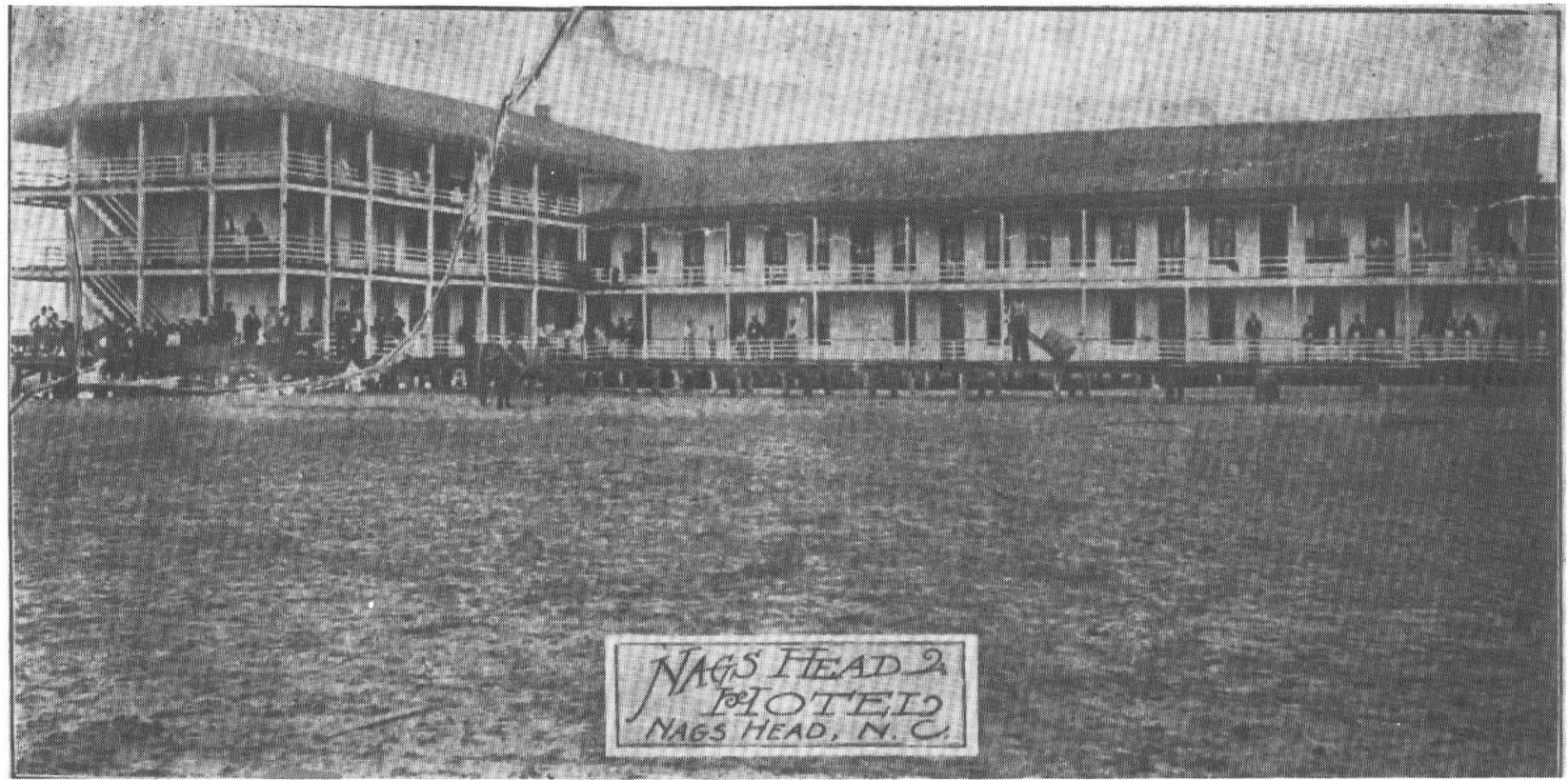

Figure 39. Nags Head Hotel in 1898. (Source: National Park Service.)

In 1933, after one of the most severe hurricanes on record, steps were taken to stabilize the moving sands. It was not uncommon for storm overwash to sweep across some parts of the island from ocean to sound (fig. 40). The National Park Service, in collaboration with the Civilian Conservation Corps, proposed a massive sand-fixation program (Croft, 1934). Between 1933 and 1940, 600 miles of sand fence were constructed on 115 miles of beach. To further stabilize the dunes, 142 million square feet of grass and 2.5 million seedlings, trees, and shrubs were planted (Dunbar, 1958). In 1935, free-ranging of livestock was prohibited from Currituck to Hatteras Inlet. Two years later, the National Park Service proposed that the Cape Hatteras National Seashore be established (Roush, 1968).

Although not completed until 1953, the new National Seashore (30,000 acres) included most of the Outer Banks between Nags Head and Ocracoke Inlet (fig. 41), excluding the villages of Rodanthe, Waves, Salvo, Avon, Buxton, Frisco, Hatteras, and Ocracoke. Two factors contributed to the establishment of the first National Seashore. Unquestionably, this was one of the world's best examples of a barrier island

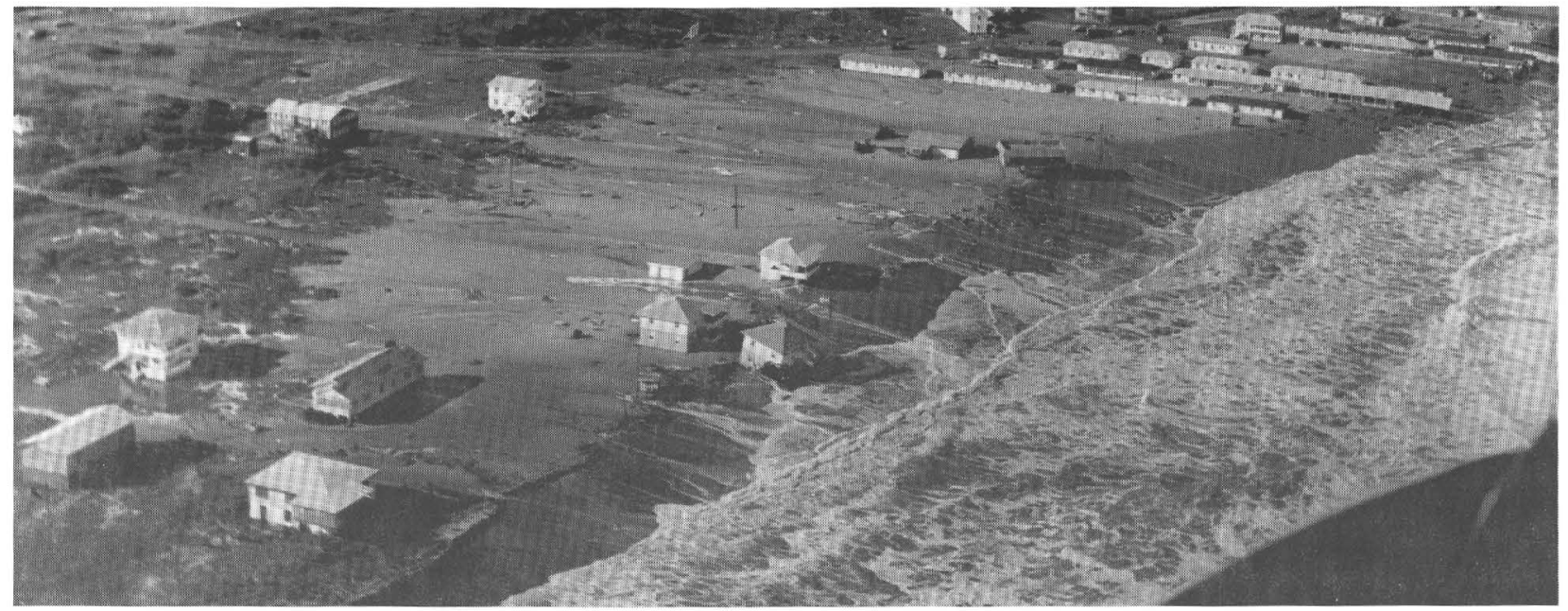

Figure 40. Overwash at Cape Hatteras, 1962. (Source: R. Dolan.) 
environment, rich in quality and diversity. Second, erosion was becoming a serious problem, and concern that the islands would soon disappear was growing.

Even though the shoreline advanced to within 150 feet of the historic Cape Hatteras Lighthouse and coastal development was continuing at a rapid pace, much disagreement occurred about having the Outer Banks under Federal control. It was not until Andrew Mellon donated over $\$ 600,000$ for the project, and the State of North Carolina matched his gift that the park became a reality (Stick, 1958).

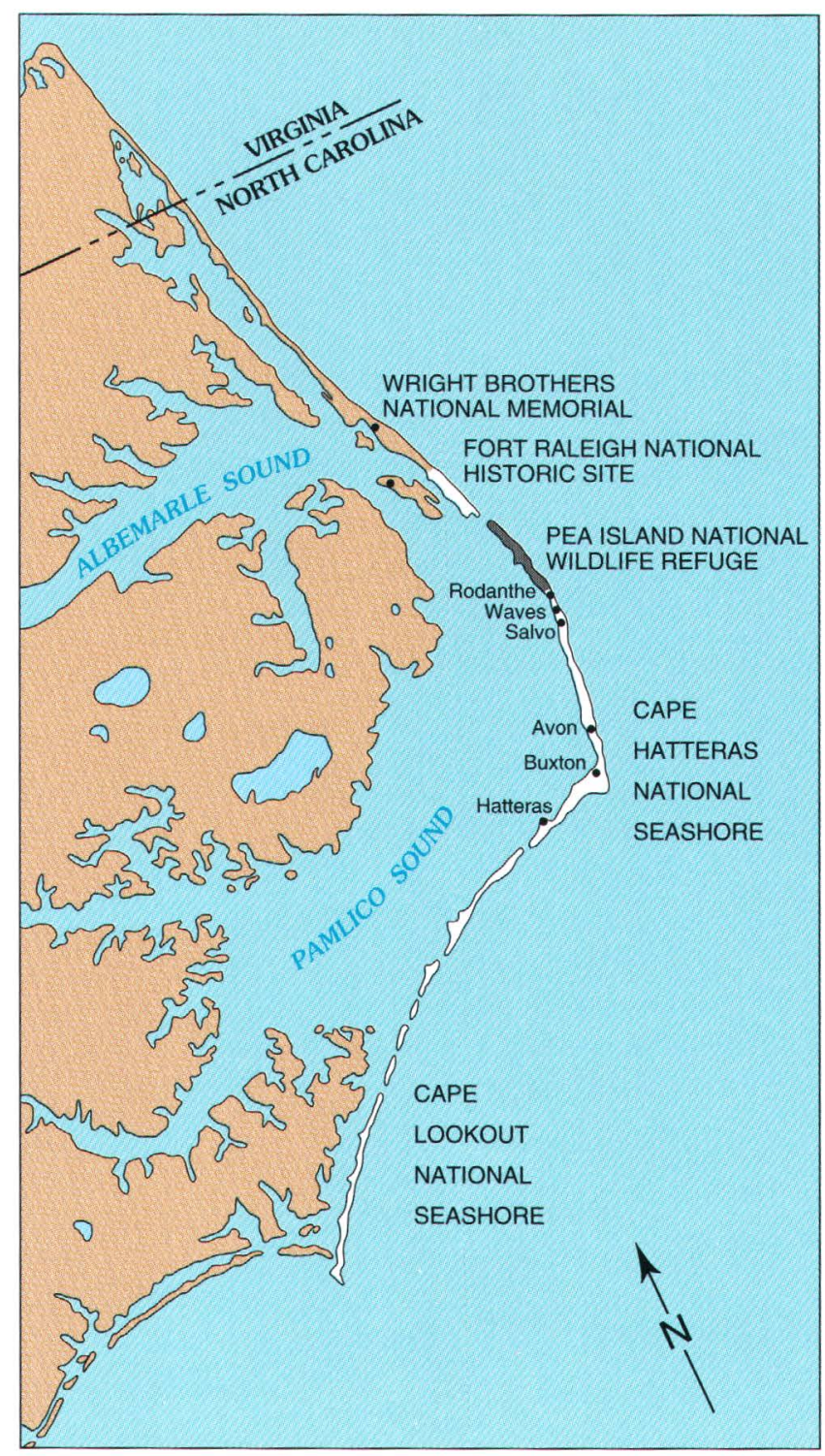

Figure 41. The distribution of federally owned and managed land along the Outer Banks.
Ownership of the land by the National Park Service halted construction south of Nags Head except, of course, in the exempted villages. Headquartered at Manteo, the Park Service also holds jurisdiction over the Wright Brothers National Memorial at Kill Devil Hills and over the Fort Raleigh National Historical Site on Roanoke Island (fig. 41).

Cape Lookout National Seashore was authorized in 1966 before Core and Shackleford Banks underwent any major development. Even though not officially transferred to the National Park Service until 1976, this authorization prevented many problems that occurred north of Cape Hatteras. The boundaries of the park extend 58 miles from Ocracoke Inlet to Beaufort Inlet and include Portsmouth Island, Core Banks, and Shackleford Banks (24,500 acres). At the present time, Cape Lookout National Seashore has no roads or bridges and remains, for the most part, in its natural state.

\section{RECENT TRENDS IN LAND USE}

Many Atlantic and Gulf coast barrier islands have been developed and highly modified in the last two decades. Freshwater supplies are commonly overtaxed, and waste products have changed the ecological balance of adjacent coastal wetlands. Often the changes on barrier islands during storms are catastrophic, in that homes and commercial facilities built close to the shoreline are destroyed. The Ash Wednesday storm of 1962 serves as an example of an extreme event along the mid-Atlantic coast. Damage to property amounted to more than $\$ 500$ million (1962 dollars), and 32 lives were lost (Podufaly, 1962). Unfortunately, this devastation was soon forgotten, and rapid shore-zone development has continued.

Much of the development shown in figure 42 has taken place since the 1962 storm. The actual overwash zone of that storm was about 350 feet wide in this area. After the storm, for example, 869 buildings remained within 1,200 acres of the overwash zone in Nags Head. Today there are 1,304 buildings in the same hazardous area (Dolan, Hayden, and Lins, 1980), an increase of 34 percent. Each year, erosion and storm surge take a toll on the buildings along the Outer Banks (fig. 43). 

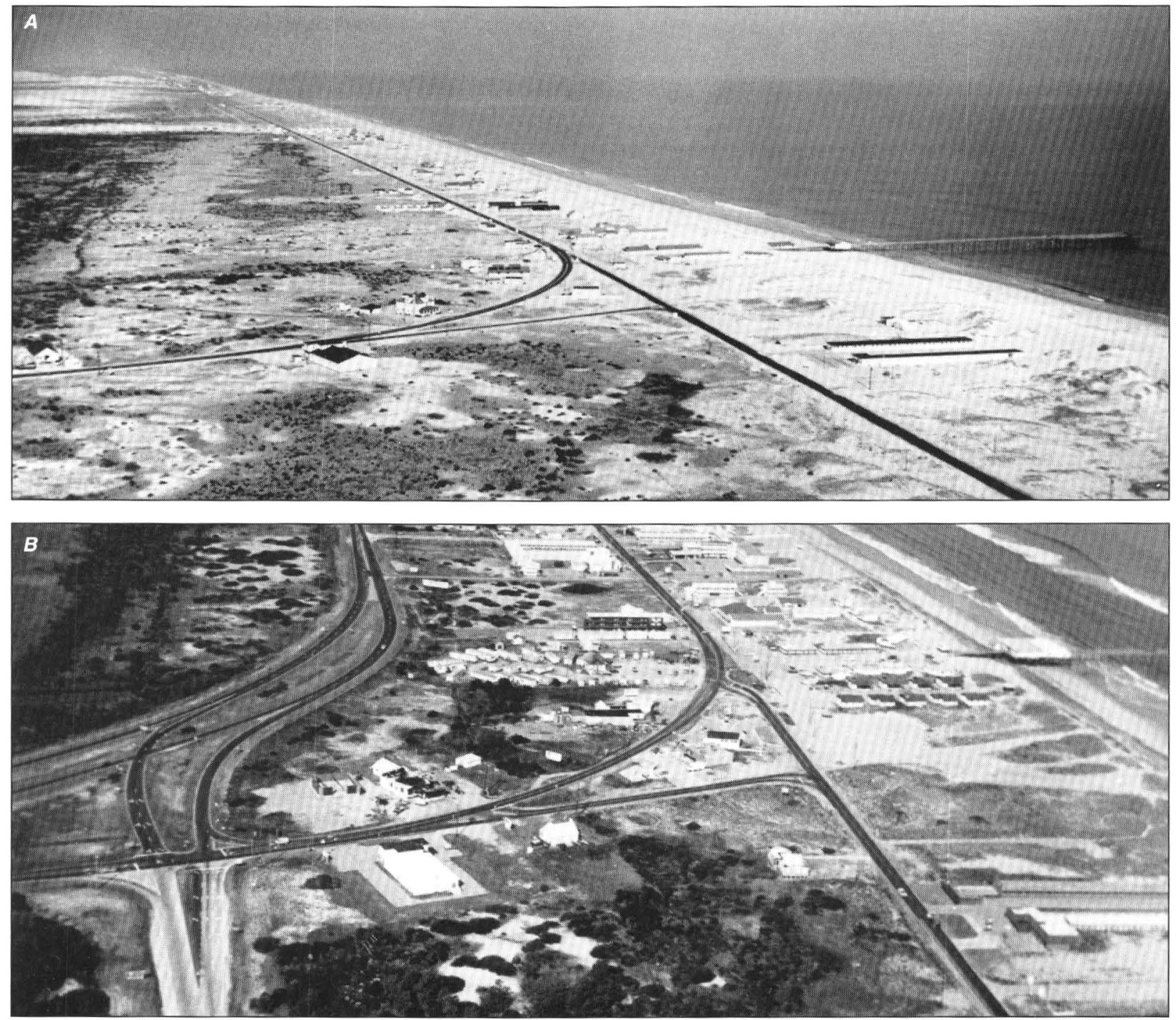

Figure 42. Pattern of development at Nags Head. A, 1958. B, 1979. (Source: National Park Service.) 


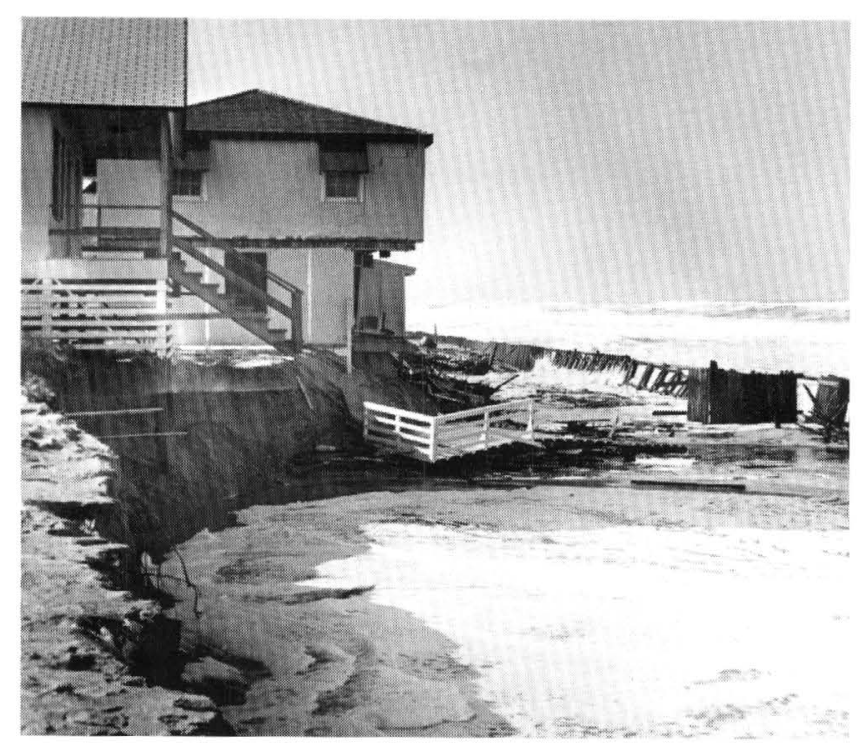

Figure 43. Property damage during a 1972 storm at Kitty Hawk. (Source: R. Dolan.)

Using categories based on the U.S. Geological Survey's nationwide land use and land cover mapping program, figure 44 shows a cross section of the location of typical land use types found on barrier islands (Anderson and others, 1976). Table 1 gives the natural processes responsible for change, the normal period of landscape response, and assessments of the stability and vulnerability of each land use and land cover category.

Recent trends in development on the Atlantic and Gulf coast barrier islands have been analyzed by the U.S. Geological Survey (Lins, 1980). Of the nearly 300 islands surveyed, roughly 70 are developed or urbanized; these areas include Atlantic City, New Jersey, Ocean City, Maryland, Virginia Beach, Virginia, Wrightsville Beach, North Carolina, Hilton Head, South Carolina, Jekyll Island, Georgia, Miami Beach, Florida, and Galveston Island, Texas. About 80 others have been purchased for or included within State and local recreation areas or preserves. The Federal Government has acquired 15 of the largest barrier islands for wildlife refuges and national seashores. The remaining 135 islands are privately owned and largely undeveloped (Clark and Turner, 1976).

The U.S. Geological Survey's study analyzed changes in land use and land cover on Atlantic and Gulf coast barrier islands for the period from 1945 to 1975. Land used for urban development has increased by 140,000 acres, or 153 percent, during this 30 -year period. Urban land accounted for only 5.5 percent of

Table 1. Dominant coastal processes associated with land use and land cover types (Source: U.S. Geological Survey.)

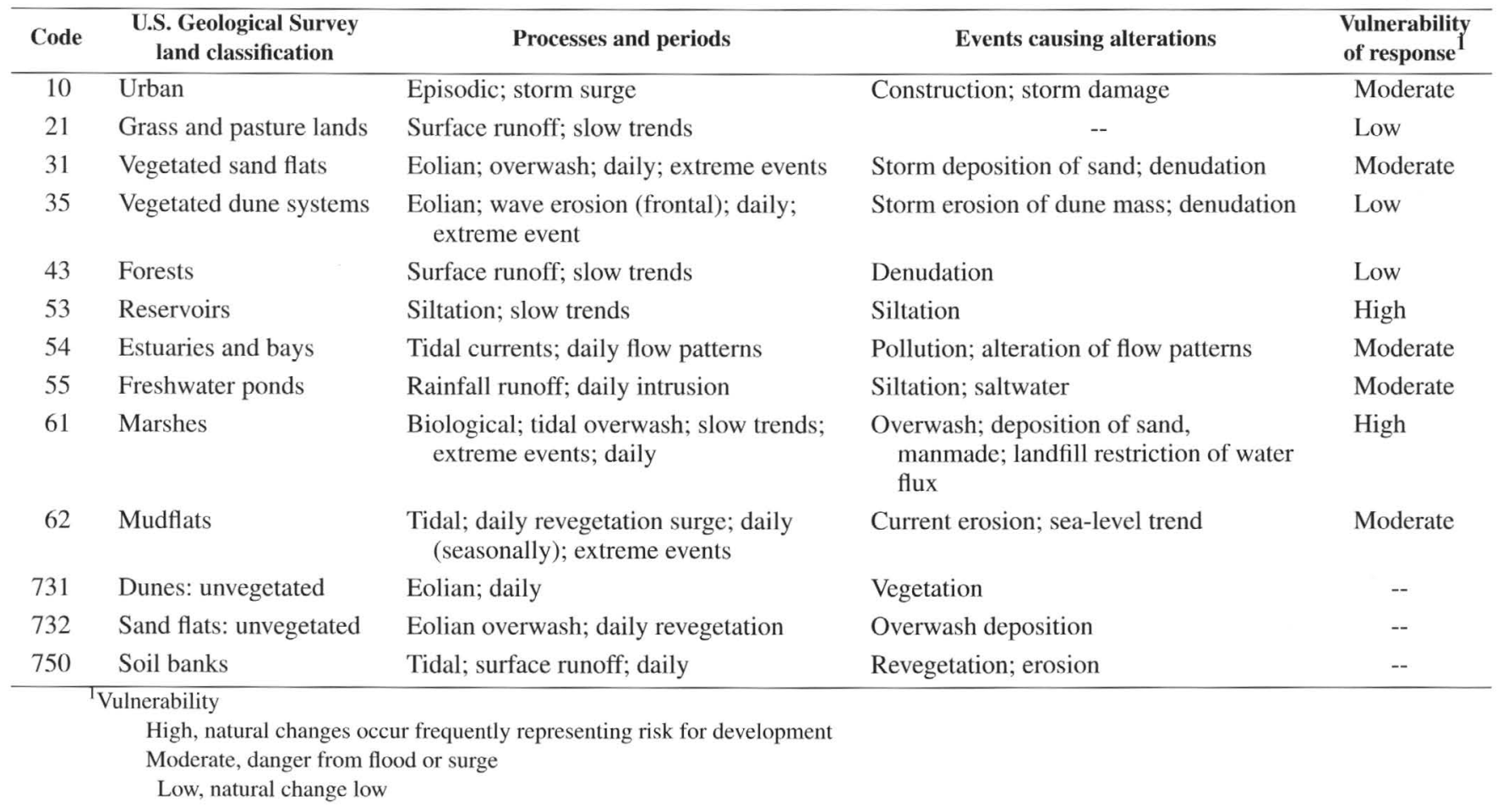


the total 1.7 million acres in 1945 , but, in 1975 , it accounted for nearly 14 percent. Most development occurred in wetland areas (80,000 acres) and, to a lesser extent, in forests (16,000 acres) and on barren lands (sand flats and overwash fans, 7,000 acres).

Four categories-wetland, urban or built-up land, barren land (sand flats and overwash fans), and maritime forests-account for 90 percent of the total barrier island area. Despite the rapid expansion of residential and commercial development, the dominant land cover type on barrier islands in 1975 was wetlands. Barren land occupied another 250,000 acres, or roughly 15 percent, and maritime forests covered 150,000 acres, or about 9 percent. It is noteworthy that the area of urban land equaled that of barren land. Furthermore, the 14-percent urban area represents a very large relative percentage - only 3 percent of the total land area in the United States is urban (Hart, 1975).

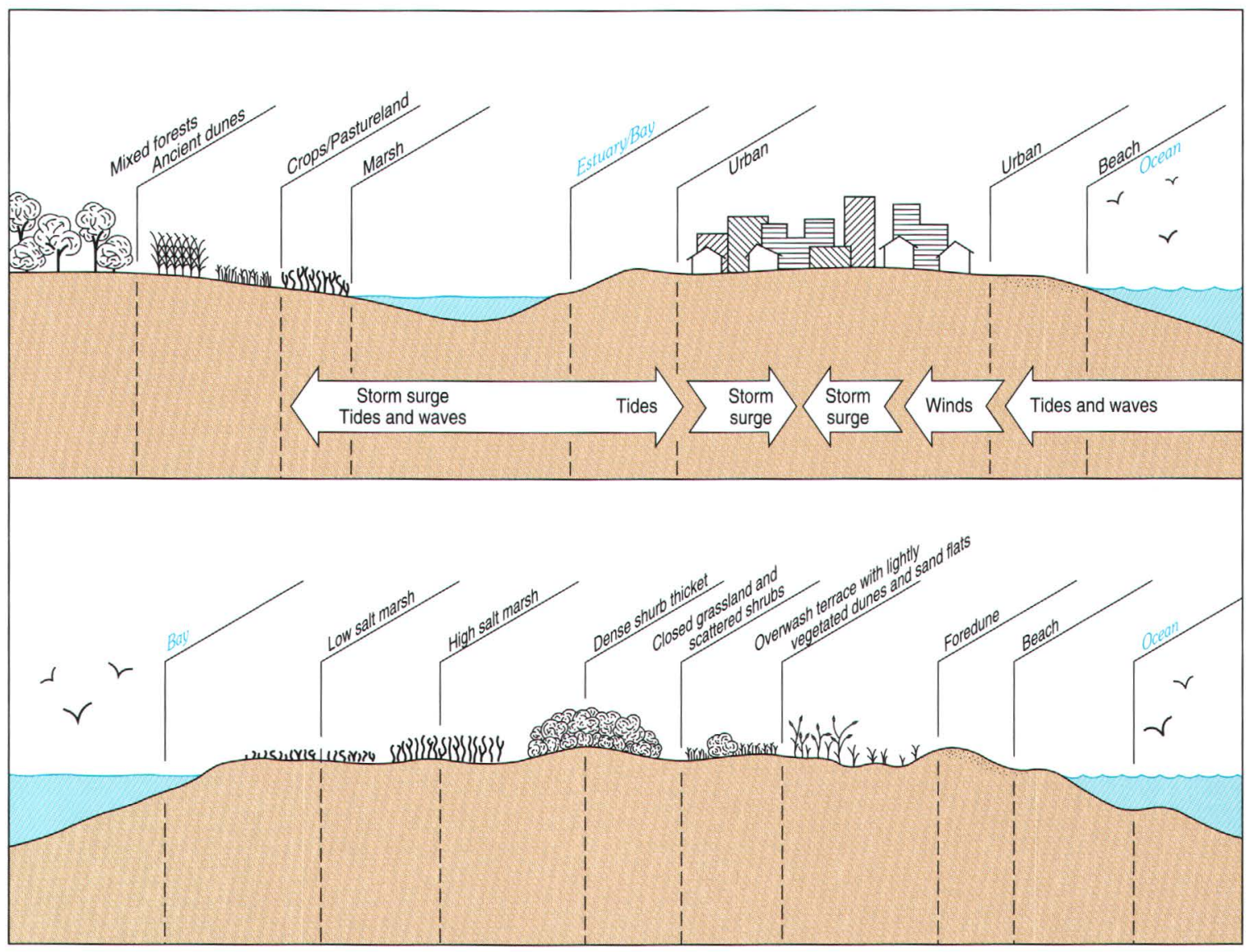

Figure 44. Cross-sectional view of developed and undeveloped barrier islands, depicting general locations of land-use and land-cover types in relation to dominant shoreline processes. (Source: R. Dolan.) 


\section{SHORELINE PROCESSES: EROSION AND OVERWASH}

The North Carolina barrier islands are, to the geologist, temporary features of the coastal environment. Since the last ice age, the level of the sea has been rising, causing a steady landward migration of the barrier islands (Kraft, 1971). This migration, which continues today, is forced incrementally by the passage of storms that drive sand along and across the islands. A characteristic island configuration is a broad beach, a dune field, overwash terraces, and a fringing marsh on the sound side of the island.

An early settlement of the sound side of the islands (fig. 45) was due to an awareness of the hazards associated with erosion and storm overwash. During the 1930's, programs designed to control overwash processes focused on sand stabilization (Dolan, Godfrey, and Odum, 1973). Sand fences were erected on the broad beaches (fig. 46), trapping wind-blown sand and forming an unbroken chain of barrier dunes. Once these dunes were established, they were further stabilized with vegetation and were fertilized periodically to ensure rapid and dense growth. Consequently, all but the most severe storm overwashes were contained seaward of the barrier dunes, and the dunes provided a margin of protection. As a result, land use patterns changed dramatically. Villages spread rapidly seaward to the barrier dunes,

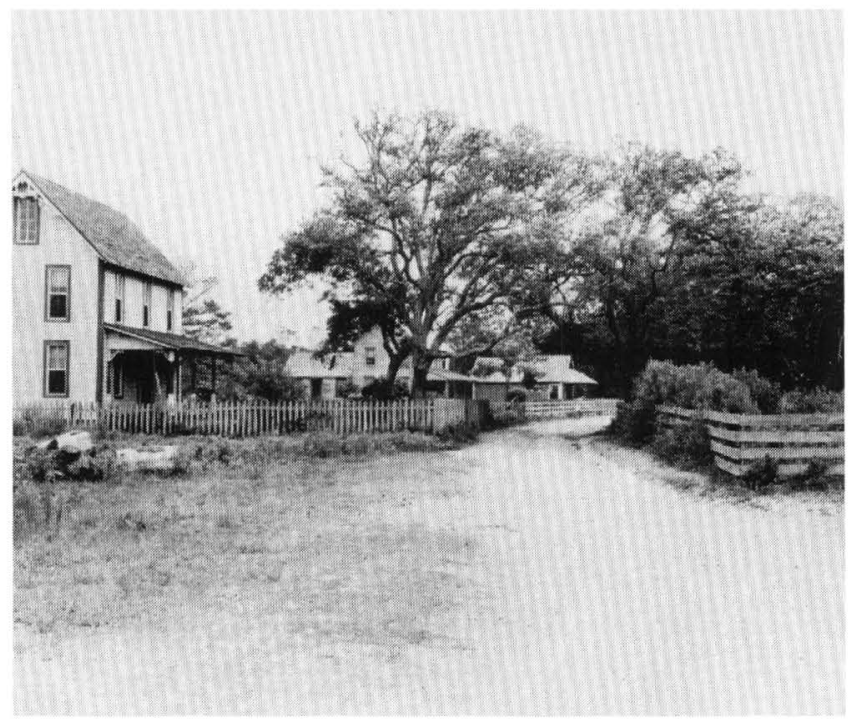

Figure 45. Village of Frisco (near Cape Hatteras) in 1936. (Source: National Park Service.)

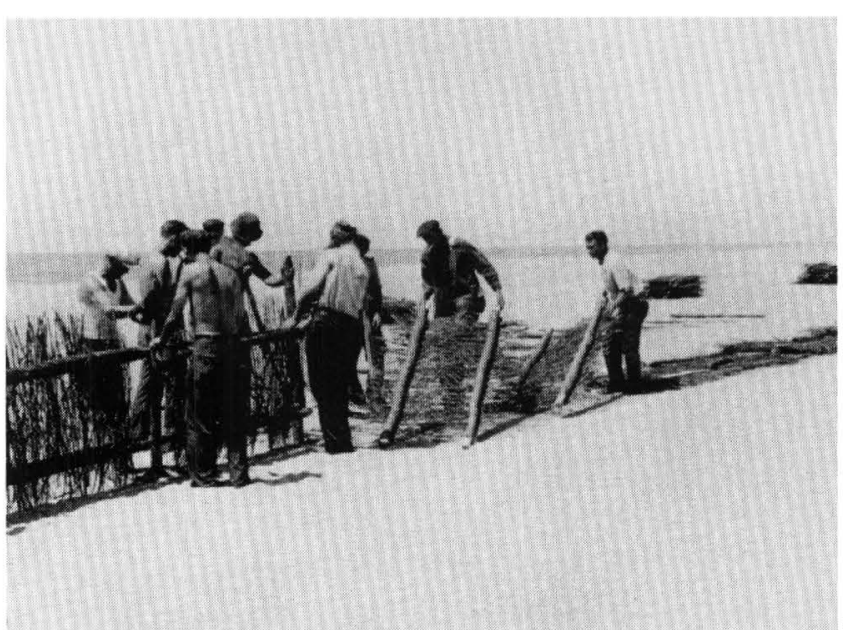

Figure 46. Sand fencing in 1936 to build barrier dunes along Hatteras Island. (Source: National Park Service.)

and roadbeds and utility lines were constructed along the length of the islands.

The Outer Banks have changed from a system dominated by natural processes to a stabilized system. The development cautiousness of earlier decades has diminished concurrently. As a result of the continuing rise in sea level and of the restriction of waves and storm surge to the beach, however, the resultant prevailing erosion of the beach has been rapid. With the narrowing of the beach, progressively smaller storm-generated waves and surges have eroded the barrier dunes (fig. 47). It was inevitable that a serious problem would occur because the processes of erosion and overwash have continued forcing the shoreline landward, whereas the line of man's development, once it was established in the 1930's, has remained constant.

As indicated earlier, coastal erosion and deposition are functions of three interrelated factors: the amount and kind of sediment within a coastal area, the power of the erosional forces, and the stability of sea level. The shoreline recedes when the forces of erosion exceed the amount of sediment supplied to the system. The greater the deficiency of sand or the higher the wave force, the more rapid the rate of erosion. Any one of these three factors can vary through time and change the balance. It should be stressed that beach erosion is a natural process and becomes a serious problem, or hazard, only when man's structures are in the path of shoreline recession. As shown by maps and aerial photographs, the shoreline of the Outer Banks 


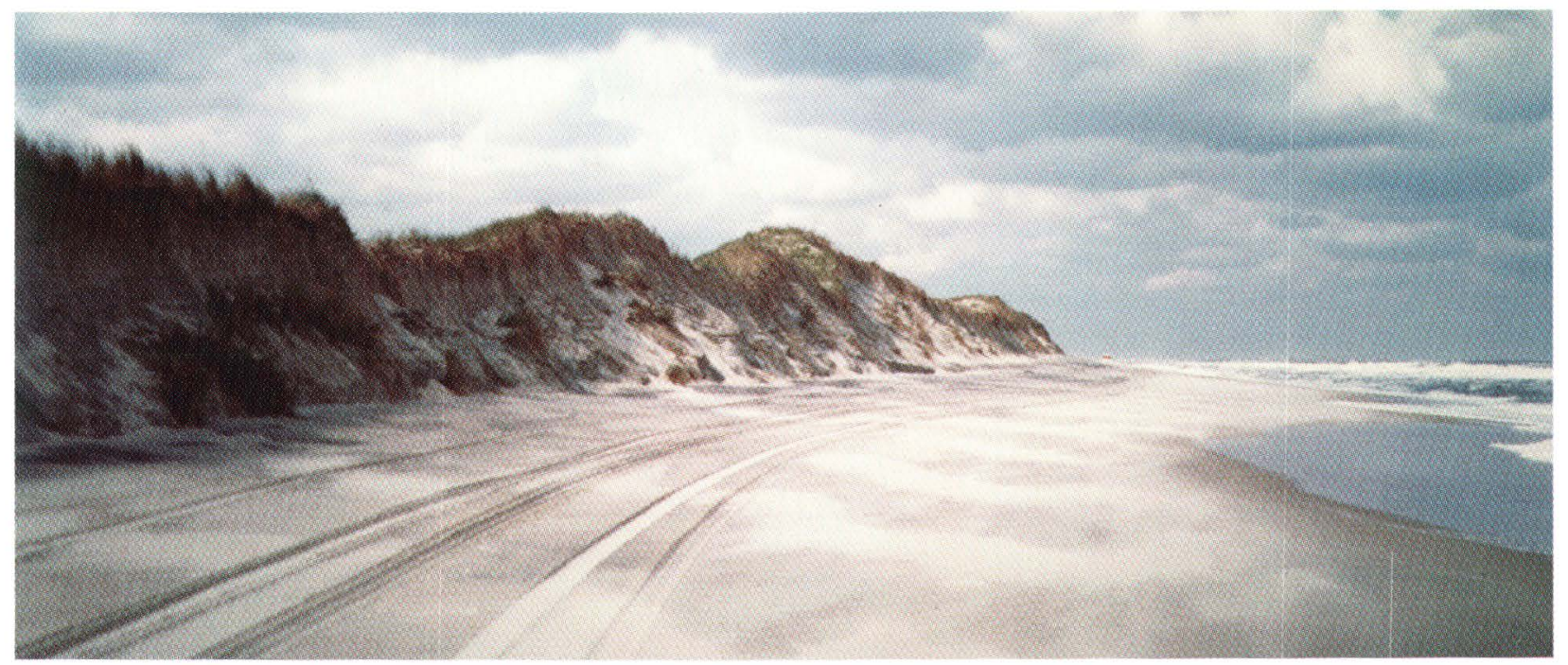

Figure 47. The last remains of the large barrier dunes on Pea Island. Shoreline recession is eroding the dunes. (Source: R. Dolan.)

has been moving toward the mainland at the rate of 3 to 5 feet per year for more than 100 years (Hayden, Dolan, and Ross, 1979).

Despite the well-known, long-term trend of barrier island migration, the effects of periodic storms (fig. 48), and repeated warnings from the National Oceanic and Atmospheric Administration, the Department of the Interior, and the U.S. Army Corps of Engineers, many coastal zone planners and developers seem to have presumed that the beaches and barrier islands are stable or that they can be engineered to remain stable. This attitude is due to the lack of detailed information available to the planners, land developers, and the general public and to the difficulty and expense of collecting accurate data on shoreline changes and storm overwash.

Analysis of historical changes in a shoreline and overwash zone requires repeated sampling in space and time. Although this information can be obtained from ground surveys, maps, and charts, our research leads us to believe that repetitive aerial photography is the only reliable source for cost-effective, high-resolution, regional scale analysis of shoreline dynamics along the Outer Banks. (See also Knowles, Langfelder, and McDonald, 1973; Langfelder, Stafford, and Amein, 1968.) Consequently, a common-scale mapping system has been used, developed by Dolan, Hayden, and Heywood (1978) to provide a uniform data base for both intrabarrier and interbarrier island comparisons.
The common-scale mapping system is used to produce and analyze data on shoreline and overwash penetration changes and rates of change at 330-foot intervals along the Outer Banks of North Carolina. These data span more than 15 years for 100 percent of the study area, more than 25 years for 91 percent of the area, and more than 30 years for 53 percent (Dolan, Hayden, and Heywood, 1978).

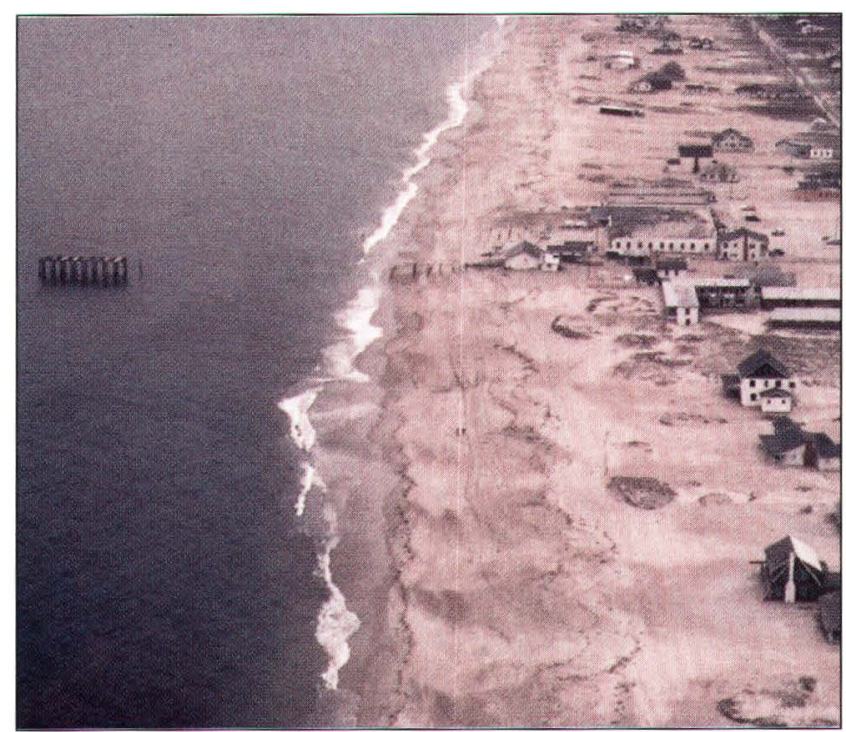

Figure 48. Pattern of storm-surge penetration for the March 7, 1962, storm at Nags Head. (Source: R. Dolan.) 
The common-scale data base is used primarily to predict future positions of the shoreline and the landward limits of overwash damage zones on the assumption that recent history is the key to the future. The data required for these calculations are the mean rates of change of the shoreline and overwash line and the standard deviations of both rates.

The landward limit of the shoreline at some time in the future can be predicted on a probabilistic basis using the rate-of-change data and standard deviations. At a 50-percent probability level, the change in the position is a product of the rate of shoreline change times the defined interval of time. Shoreline positions at other probability levels also may be calculated by using appropriate fractions of the standard deviation of the rate of change. Details of these calculations are given by Dolan, Hayden, and Heywood (1978). A similar procedure is given for probabilistic estimates of the change in the position of the landward limit of overwash penetration at defined times in the future. These projections assume that the trends of the past 30 to 40 years will continue essentially unaltered.

Using this approach, the hazards of erosion and the danger of destructive overwash for several barrier islands have been examined; for example, barring anthropogenic activities or alterations, the probability is 1 in 2 that the shoreline of Nags Head will be 300 feet landward of its current position by the year 2010. Using a probability of 1 in 7, the estimate increases to 580 feet. The landward limit of overwash penetration for the same period is estimated at 265 and 550 feet, using the 1-in-2 and 1-in-7 probability levels, respectively. Clearly, overwash damage increases proportionally with the magnitude of shoreline recession or erosion. One hazard is, therefore, a function of the other-a problem for anyone trying to predict the risks of living on a barrier island.

\section{Shoreline Erosion and the Lost Colony}

Sir Walter Raleigh's first English colony in America was established in 1585 on the Outer Banks on the northern end of Roanoke Island, North Carolina (fig. 49). The "Cittie of Ralegh in Virginia" was, however, left to its own resources in 1587 when John White, the colony's governor, returned to England for supplies. Because England was on the verge of war with Spain at this time, suitable ships could not be spared for the relief of the colony. When White finally returned in the summer of 1590 , he found the colonists had disappeared but had left behind the remains of a crude fortlike settlement and, carved on a tree or post, the word "Croatoan." The fate of the Lost Colony remains a mystery to this day (Harrington, 1962).

Although the location of a fort (Fort Raleigh), which was built before the return of John White, has been verified and well documented, neither research through old records nor archaeological fieldwork has established the actual location of the settlement. Early records reveal that the site was almost certainly near

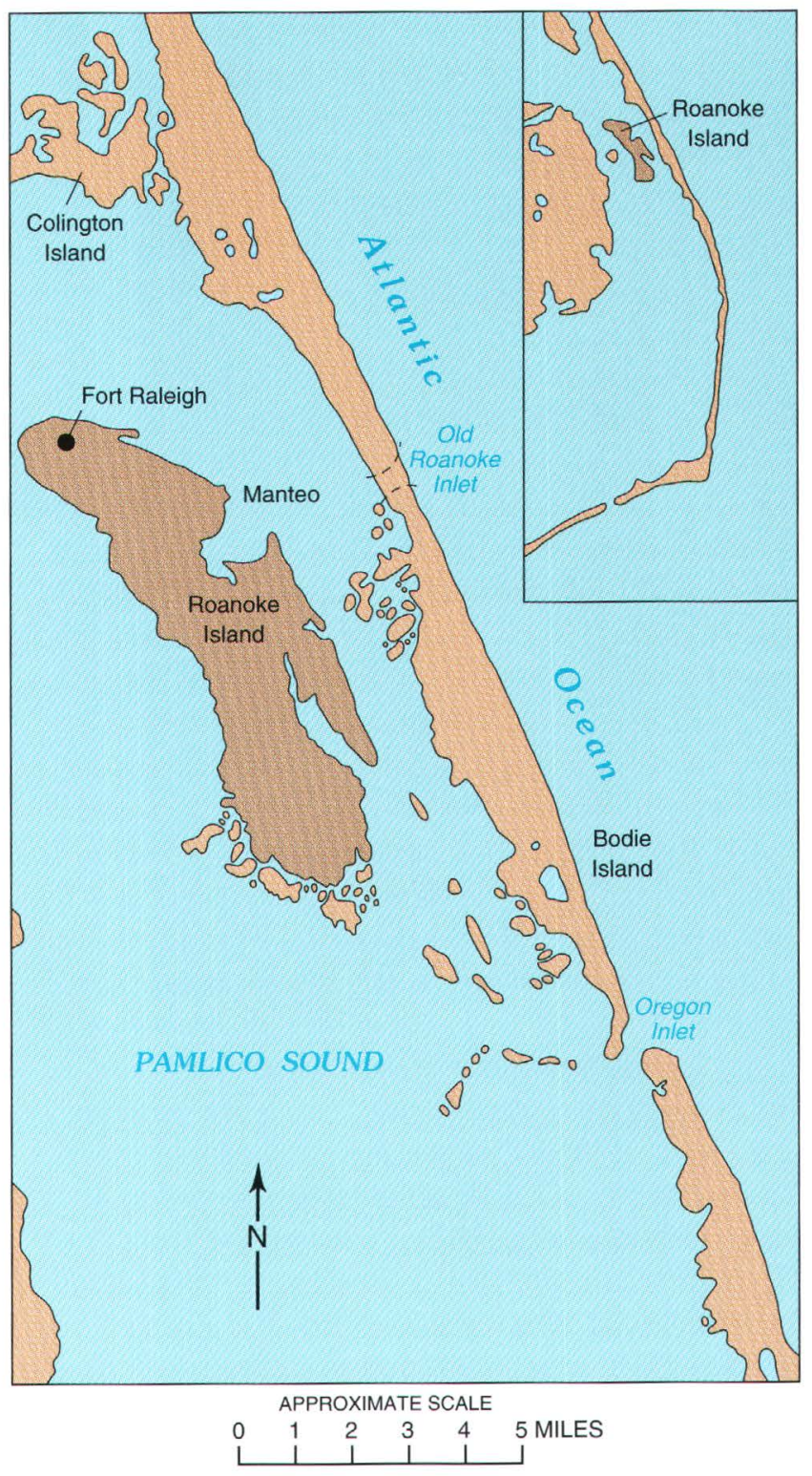

Figure 49. Location of Roanoke Island and Fort Raleigh. 
the fort and close to the shore of Roanoke Island. Archaeologists believe that it would be reasonable to accept any evidence found in a strip approximately one-quarter of a mile wide along the northern shore of Roanoke Island (Harrington, 1962). One of the problems that archaeologists generally have ignored, however, is that the shoreline of northern Roanoke Island has not remained stable during the almost 400year period since the settlement was established.

Roanoke Island is part of the Pamlico Terrace (Pleistocene), and, at one time, it may have been an interfluve (situated between two rivers). The southern end of the island lies only slightly above sea level, and the northern end has a well-developed, 8- to 10-foot bluff with a Pleistocene soil horizon and postglacial dune sands resting on the terrace surface. Separating the Pleistocene layer from the postglacial is a thin layer of charcoal, the remnant of a forest fire that swept the northern end of the island at some unknown earlier date.

Maps and charts dating from the mid-1800's and those prepared by the U.S. Army Corps of Engineers and the Coast and Geodetic Survey were used to establish historic trends of shoreline change of Roanoke Island. Aerial photographs, dated 1943, 1963 , and 1970, coupled with field measurements over the past decade, were used to determine more recent trends. Although charts and maps of Roanoke Island date from the 1500 's, the earliest ones were too small in scale or not sufficiently accurate to be of use.

For the northern part of Roanoke Island, all areas showed varying amounts of shoreline erosion for the 119-year period, 1851 to 1970 . The 1851,1903 , and 1970 shorelines and our estimated 1585 shoreline are shown in figure 50A. The only interruption of the natural erosional patterns occurred when a break-water and groin field were built along the northeast shore in the 1950's.

Several striking shoreline changes also are shown in figure 50A. Etheridge Point, for example, completely disappeared during the last century. Measurements taken from these figures show that Roanoke Island lost 928 feet between 1851 and 1970. Of this amount, 770 feet of shoreline eroded between 1851 and 1903. The remaining 158 feet has been lost since 1903. Between 1903 and 1950, the tip of the spit on the northeastern end of Roanoke Island migrated 2,500 feet southeast, a rate of over 50 feet per year. The spit does not appear on the 1851 map and, thus, was formed sometime after that date.
Recent trends in shoreline change were determined for the period 1950 to 1970 . Several characteristic changes, shown in figure $50 \mathrm{~B}$, include the following: (1) The northern shoreline west of the fort, where groins were installed to curtail erosion, accreted about 30 feet, (2) the area east of the fort, not protected by groins, receded about 80 feet, or approximately 4 feet per year, (3) the northwestern shore, from U.S. 64 to Northwest Point, showed the most erosion for the 20-year period - a loss of roughly 150 feet or about 7.5 feet per year.

Land areas facing large fetches (open water), as well as facing directions of strong winds (northwest for coastal North Carolina), have higher erosion rates. Northern Roanoke Island is alined with large fetches to the north from approximately $270^{\circ}$ to $90^{\circ}$ and, thus, the northern part of the island is subject to destructive storm waves and surges from northeasters (fig. 49).

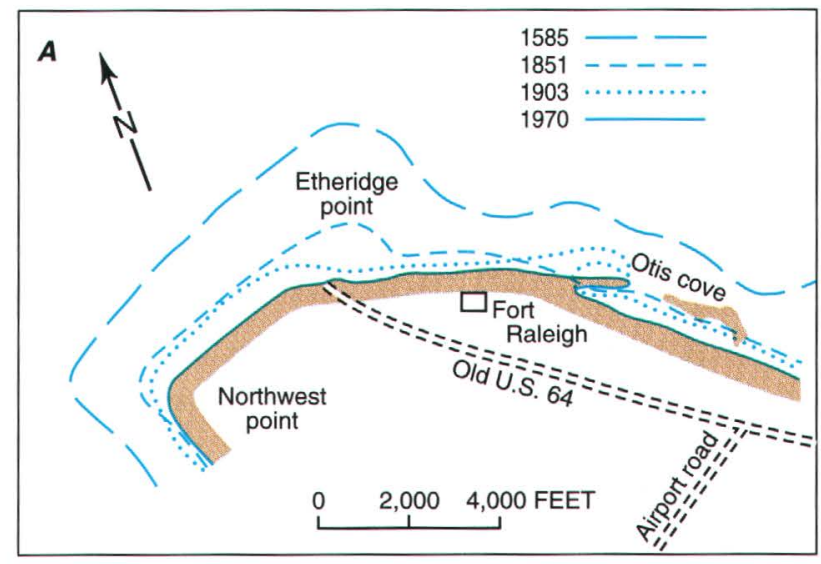

B

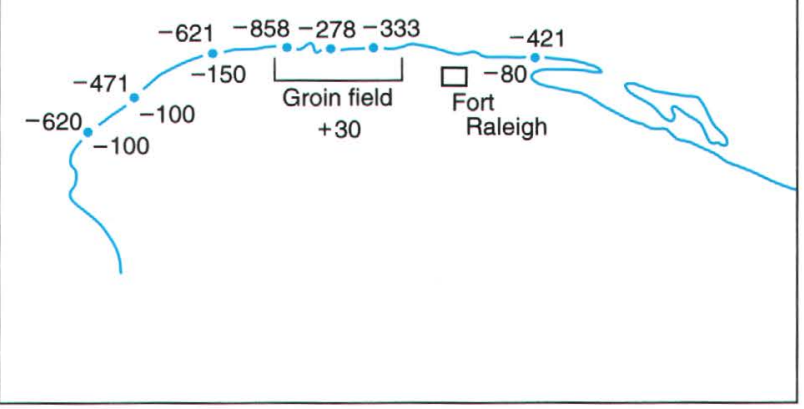

Figure 50. Area near Fort Raleigh. A, Historical shorelines for the northern end of Roanoke Island. B, Erosion for selected locations. The actual rates since 1851 are given in feet; the smaller numbers show losses from 1950 to 1970.

(Source: R. Dolan.) 
This situation constitutes a double vulnerability not found elsewhere along the Outer Banks and explains the high degree of erosion on northern Roanoke Island.

If the trend in the erosion rate for northern Roanoke Island over the last 120 years reflects the general trend since the "Cittie of Ralegh" was established almost 400 years ago, it is not surprising that evidence of the settlement site has not been discovered (fig. 50A). Projected over the nearly 400year period, the present coast from Northwest Point to U.S. 64 probably has receded more than 2,000 feet. The northeast shoreline (excluding Etheridge Point) from U.S. 64 to the Airport Road has receded an average of approximately 1,300 feet (fig. 50B). Thus shoreline recession along the entire length of northern Roanoke Island in the postsettlement period would have been over one-quarter of a mile in the very area that archaeologists believe was most likely the settlement location. Whether the erosion of the shoreline over the first 276 years after settlement equaled that of the last 120 years is, of course, speculative, but no evidence exists to suggest a significant change in the physical processes during this period. Similar rates of erosion have been established for most of the shoreline between Cape Lookout and Cape Henry (Dolan and others, 1979).

The mystery of the Lost Colony remains unsolved, and perhaps no one will ever discover the meaning of "Croatoan." An explanation for the inability of archaeologists to locate the settlement can, however, be offered. If the shoreline has receded continuously over the last four centuries, as evidence indicates, the settlement site may now be in Roanoke Sound, and many artifacts may be lost in the waters adjacent to the present shoreline.

\section{SHORELINE ENGINEERING}

Interfering with the littoral transport of sediment to provide a more stable landscape on barrier islands profoundly affects geological and ecological processes. If man artificially creates dunes that inhibit overwash and collect windblown sand, for example, then he alters overwash channels and vegetation communities and interferes with the landward migration of the islands. If groins and jetties are constructed to inhibit the longshore currents, the shoreline on one side of the groin artificially accretes while the shore on the other side erodes. Furthermore, when roads, parking lots, and campgrounds are constructed, sediment processes are altered, and freshwater runoff, plant communities, and animal habitats are changed.

As previously discussed, barrier islands recede when the amount of erosion exceeds the amount of sediment supplied to the beach energy system. The greater the deficiency of sediment or the higher the wave forces, the more rapid the rate of erosion. Along the mid-Atlantic coast, wave energy ranges from modest to high, sediment budget is primarily on the deficit side, and sea level continues to rise relative to the shoreline. Unfortunately, all these factors contribute to erosion.

Shoreline protection schemes can be summarized under three categories designed to inhibit direct attack by waves, such as seawalls, bulkheads, and revetments, inhibit currents that transport sand, such as jetties and groins, and artificially nourish beaches (U.S. Army Coastal Engineering Research Center, 1973).

\section{Seawalls}

Seawalls are expensive and only suitable when all other means of protection are impractical. In principle, the seawall is designed to absorb and reflect wave energy and to elevate the problem area above the high water line. Unfortunately, seawalls, bulkheads, and revetments do not prevent the loss of sand in front of the structures. In fact, seawalls commonly accelerate the loss of sand as the wall deflects the wave forces downward onto the beach deposits.

\section{Jetties and Groins}

Jetties and groins are obstructions placed in the path of longshore currents to trap littoral drift (fig. 51). These structures work only if (1) the littoral drift sediment is of significant volume, (2) the material is at least sand sized, and (3) the land down the beach from the groin is considered to be expendable. The reason for the last is that groins and jetties trap sand, and the sand gained at one place must be lost at another. Nourishment often is needed to fill or refill the groin or jetty compartments as sand is lost. 

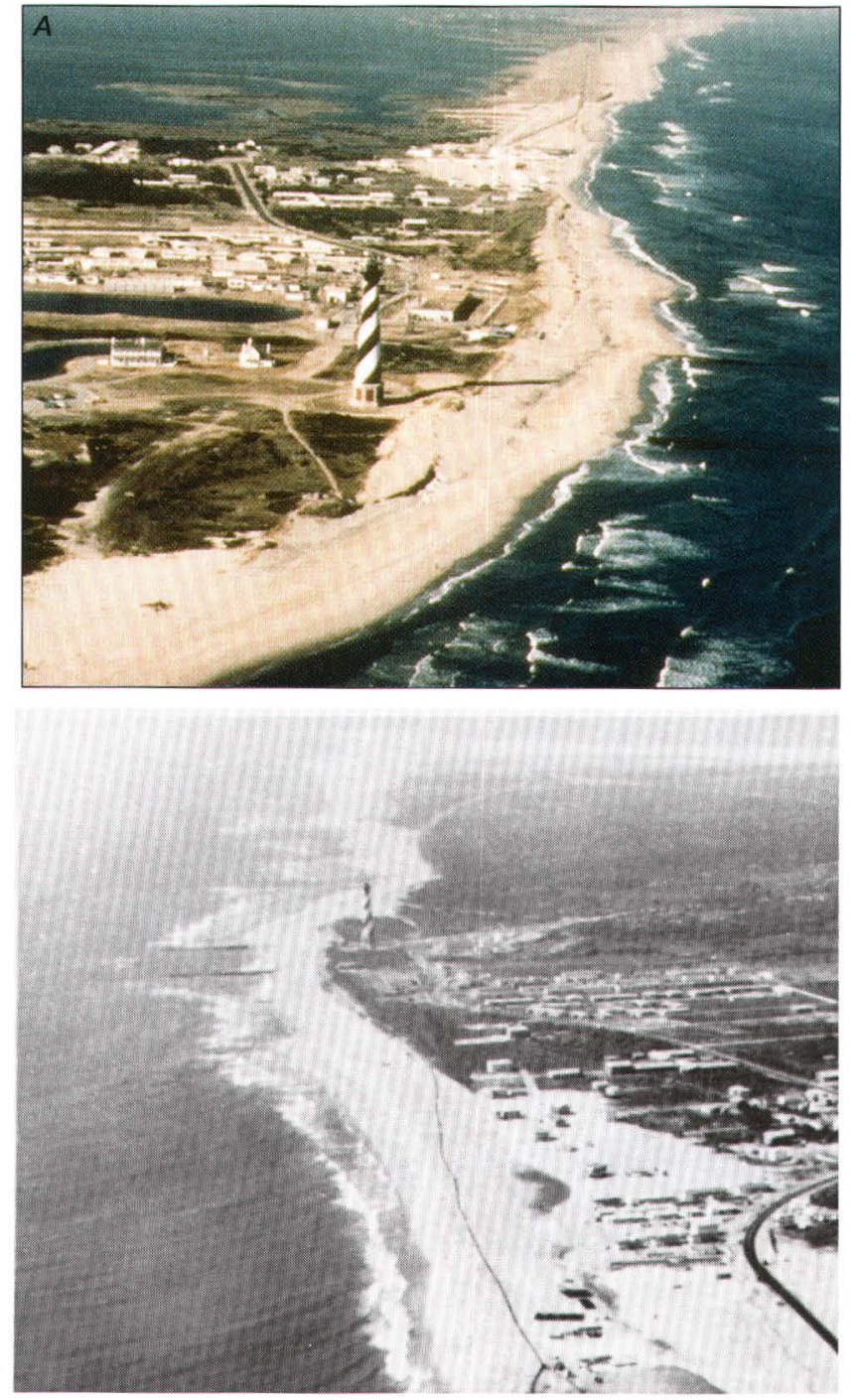

Figure 51. Cape Hatteras. A, Groins trap sand that normally moves along the shoreline, 1971, and B, Beach nourishment, 1974. (Source: R. Dolan.)

\section{Beach Nourishment}

For more than a century, coastal structures (jetties, groins, and seawalls) have been built in the inshore zone to trap sand and to protect beaches. In general, these structures collectively have aggravated problems rather than solved them. The disadvantages span a wide range of physical problems. On the other hand, artificial beach nourishment (fig. 51B) has long been considered the most desirable method of protection because (1) placement of sand on a beach does not alter the suitability of the system for recreation, (2) nourishment cannot adversely affect areas beyond the problem area, and (3) if the design fails, the effects of the "structure" are soon dissipated.
Perhaps the greatest disadvantage of artificial nourishment is that great quantities of sand of suitable quality (type and size) are not readily available. In the past, sand was dredged from sounds and bays immediately inland from the beach or transported from inland sources. Because of the recent concern about estuarine ecology, however, and because materials dredged from sounds and bays are generally too fine to be effective in beach nourishment, estuarine and bay sources have become less desirable and are no longer readily available. The only future source of large quantities of sand for nourishment of the Outer Banks appears to be offshore areas, such as Diamond Shoals and coastal inlets.

\section{Inlet Stabilization}

Since its formation in 1846, Oregon Inlet has migrated south because of accretion on its north bank (Bodie Island) and erosion on the south bank (Pea Island). The rate of movement has averaged 100 feet per year for 140 years (Dolan and Glassen, 1972). This process of accretion and erosion has caused many problems for the engineers attempting to maintain navigational channels through the inlet. The U.S. Army Corps of Engineers has found it necessary to dredge the channel every year.

Modifications of the inlet have been proposed by the Corps of Engineers to stabilize the banks, to increase the depth of the navigational channel, and to provide convenient access to a newly developed seafood processing industry at Wanchese on nearby Roanoke Island. The plan calls for construction of two rock jetties, each 1.5 miles long, on either side of the inlet (fig. 52). The estimated cost for the project is about $\$ 80$ million (1980 dollars). The project would require several years to complete. Although wide public support exists locally for the jetty project, environmental scientists and the National Park Service have serious reservations about its potential adverse environmental impact.

\section{Economics of Stabilization}

Any form of beach restoration, including artificial nourishment, is expensive. The cost per cubic yard of sand depends on the source of the material and the method and distance of its transport. This cost can 

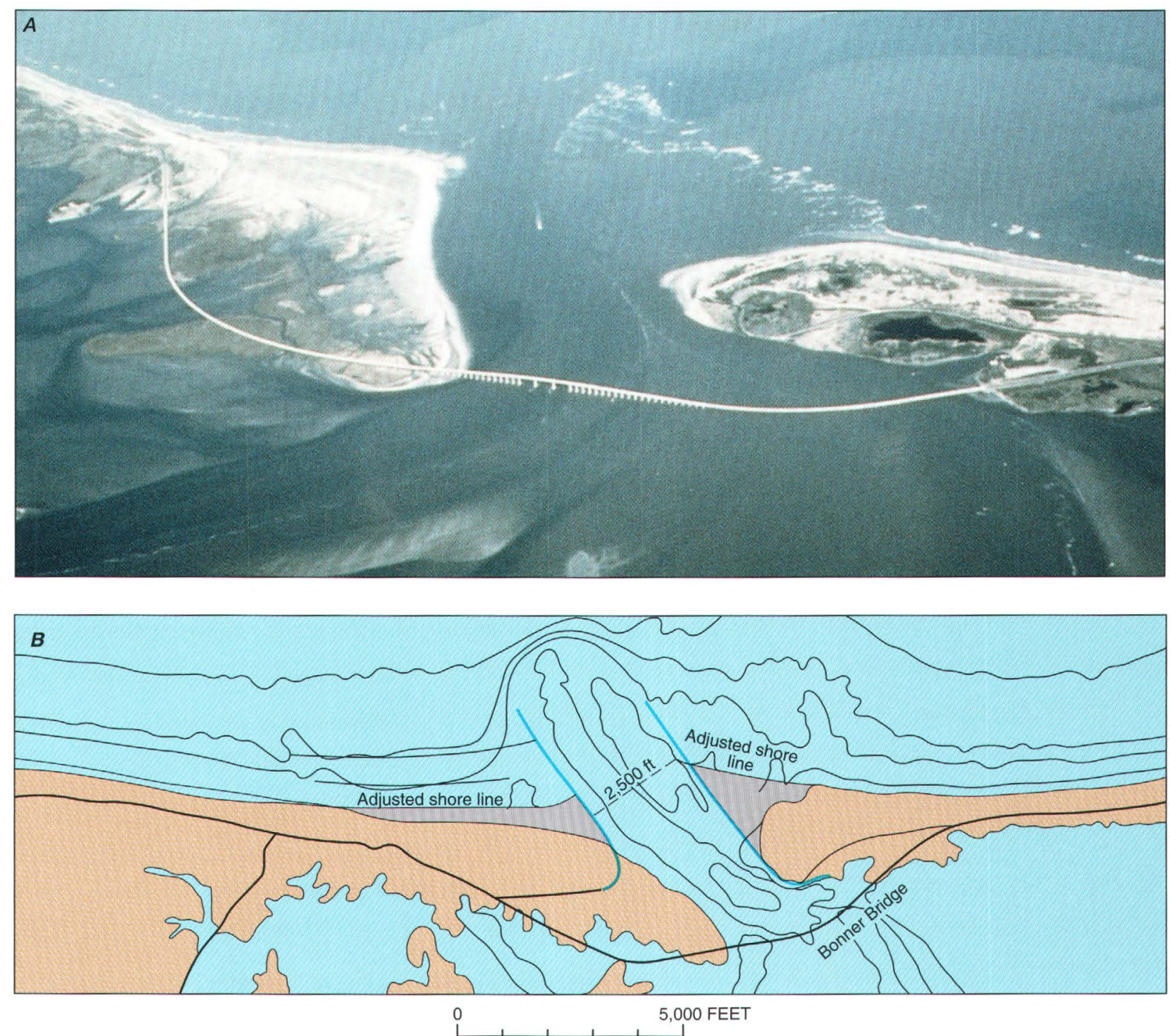

Figure 52. Oregon Inlet. A, The inlet, and B, The plan to jetty it. (Source: U.S. Army Corps of Engineers.)

range from about $\$ 3.00$ per cubic yard for sand pumped by dredge over a short distance to as much as $\$ 9.00$ per cubic yard for truck-hauled sand (1980 dollars).

The magnitude of the economic problem associated with erosion along the Outer Banks can be visualized by comparing the erosion rates and sand requirements to reach an equilibrium. The average shoreline loss for the period from 1950 to 1979 was about 150 feet (Dolan, Hayden, and Felder, 1979). Using a rule-of-thumb estimate that 2 cubic yards of sand are lost for every 1 foot of erosion per 1 foot of beach, the 30 miles of developed shoreline (over
150,000 feet) with 150 feet of erosion and 2 cubic yards equals about 45 million cubic yards of sand. Even this amount would be inadequate to reestablish the 1950 shoreline. Additional material also would be required yearly to maintain the beach in a stable position.

The nourishment method of the future will involve the inexpensive transfer of large quantities of sand from offshore sources directly into the inshore bar-trough system, which is adjacent to the beach (fig. 53). This method will eliminate the costly step of placing the material directly on the beach. Sand added to a beach is redeposited within the bar-trough system 


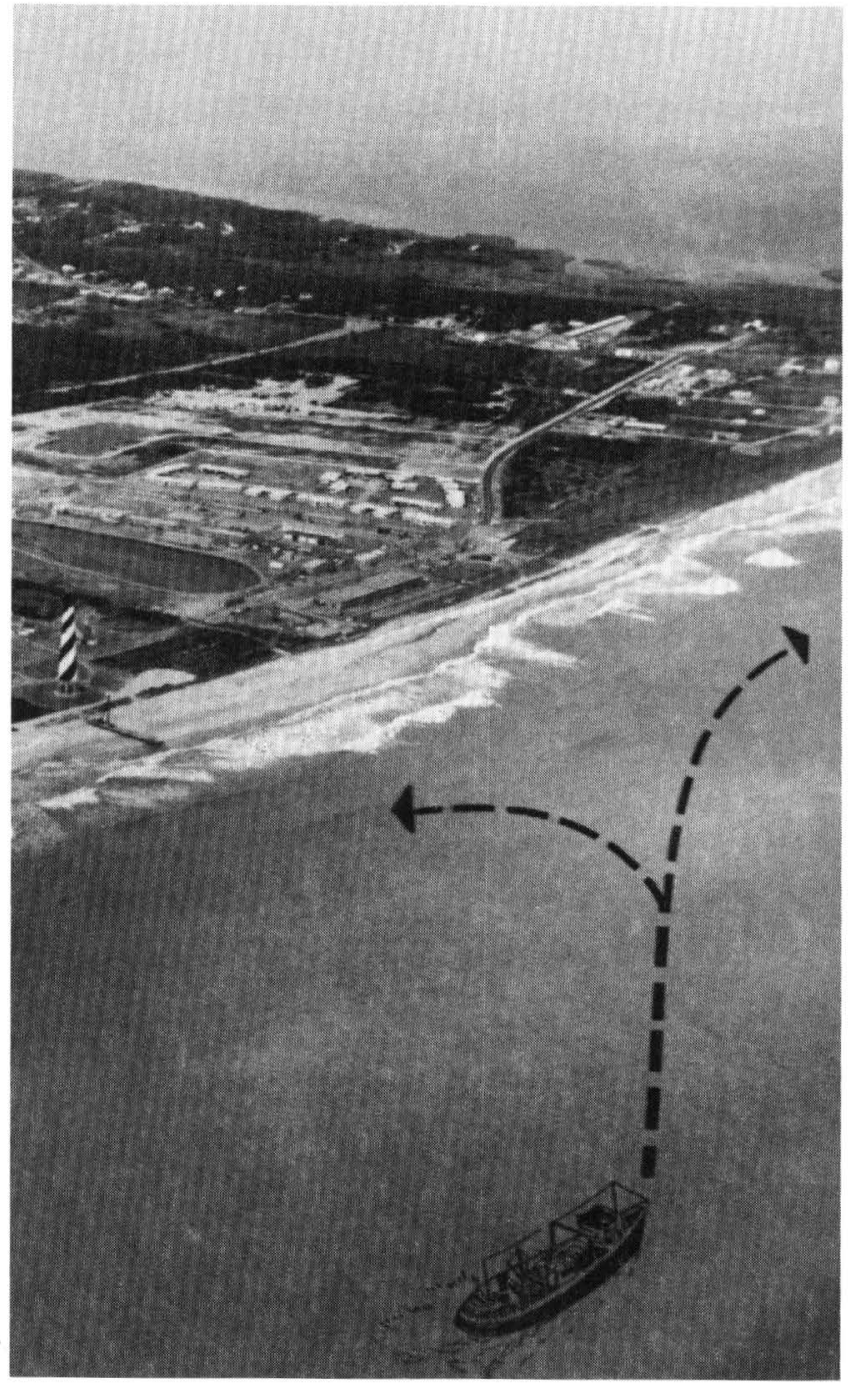

Figure 53. The concept of transferring sand from offshore shoals to the inshore zone near Cape Hatteras. (Source: R. Dolan.)

within a short period of time anyway. This method of sand transfer requires a new concept in hopper-dredge design, and one now is being developed by the Corps of Engineers. The equipment is capable of working in shallow water (12 feet or less).

Over the past two decades, tens of millions of dollars from private and public funds have been invested in attempts to stabilize and protect property on the beach along the mid-Atlantic coast. The methods available to "correct" erosion problems are limited. The best method, beach nourishment, clearly has serious economic drawbacks. In 1972, the Corps of Engineers completed a study that estimated the cost of restoring the average 50 -foot beachfront lot along the Outer Banks at about $\$ 20,000$, with an additional $\$ 1,000$ to $\$ 2,000$ per year required to maintain stability. Investments this large obviously restrict beach erosion control projects to areas where erosion has implications of national significance (Dolan and others, 1973).

\section{MAN'S IMPACT ON THE OUTER BANKS}

No accurate records have survived that describe the conditions along the North Carolina Outer Banks when European explorers arrived. The earliest known observations date from the late 18th century. By this time, the islands had been settled for at least 100 years, and large numbers of cattle, sheep, horses, and hogs had been introduced (Dunbar, 1958). For these reasons, some uncertainty exists about the extent of vegetation on the islands before the arrival of the English settlers (Cobb, 1903). Cobb suggested that the banks originally were covered by extensive vegetation and that heavy grazing and wood cutting by the early settlers partially denuded the barrier islands of their grasses and trees and created a desolate, unnatural condition.

Men and domesticated animals undoubtedly have affected the vegetation of the Outer Banks (Godfrey, 1972b). The observations of several investigators indicate, however, that vegetation on the islands always has been sparse. The regular occurrence of overwash and flood tides precludes the establishment of permanent forests, except at a few high dune areas, such as Buxton.

One way to visualize the original condition of the Outer Banks is to examine a typical barrier island such as present-day Core Banks (Brown, 1959). The typical cross section of a natural barrier island, in contrast to one that has been stabilized, presented in figure 54, shows several characteristic features. Storm waves and tides have carried sand and shells from the beach face to form a broad berm that slopes gently toward the interior of the island (Godfrey, 1972c). The width of this zone ranges from 325 to 650 feet depending on the magnitude and frequency of storms. This wide, bare berm serves as a buffer zone in which the wave energy of a moderate storm can be dissipated. Small dunes form on the berm between storms (fig. 55). 


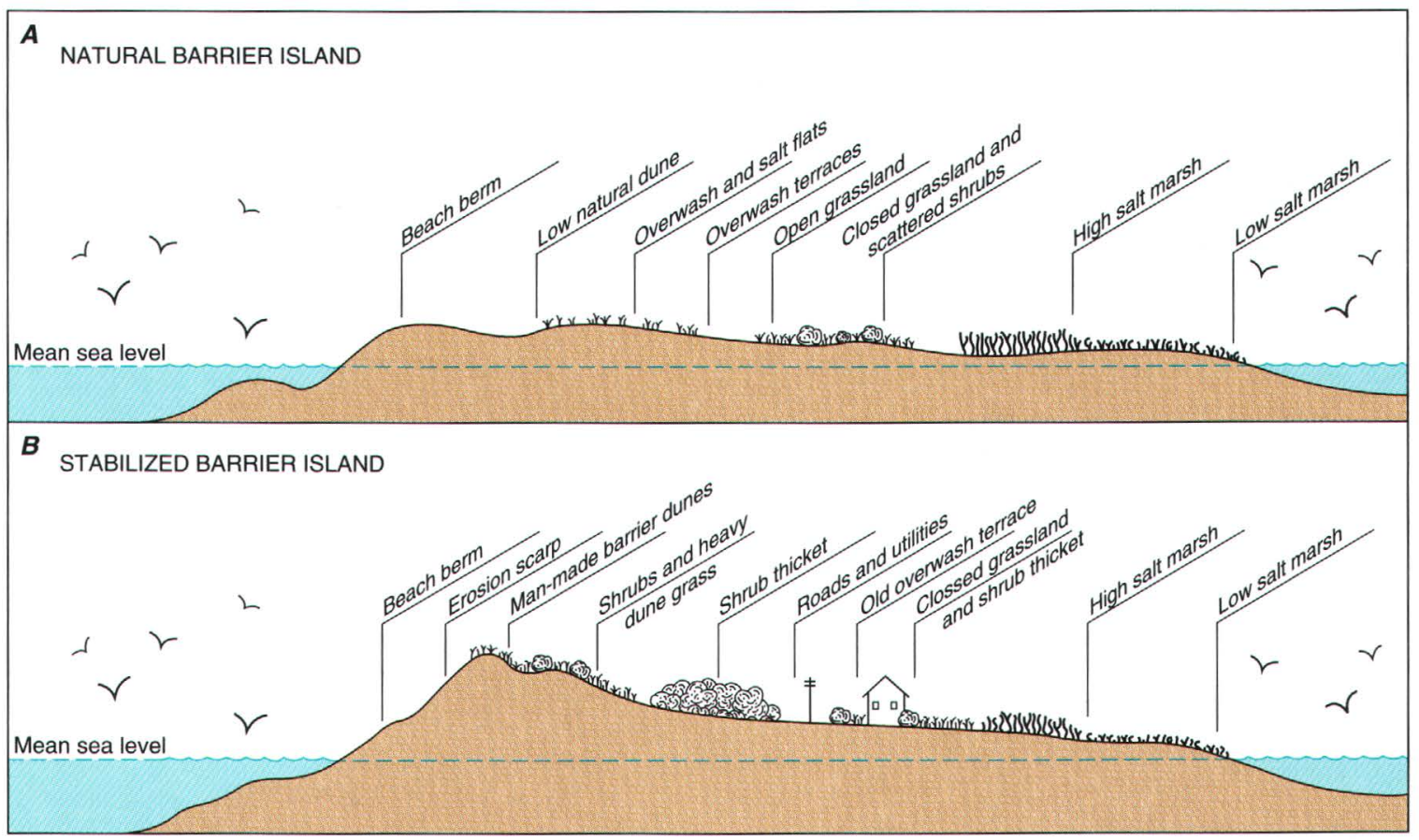

Figure 54. Idealized profiles of A, natural versus B, stabilized barrier islands. (Source: R. Dolan.)

Behind the wide berm is a zone of low, irregular dunes broken by overwash fans (fig. 56). Storm tides carry sand into the interior of the island through the depressions between dunes. The dunes form as sand accumulates around cordgrass (Spartina patens) and sea oats (Uniola paniculata). Both grasses grow upward as the dunes increase in height (Godfrey, 1972a). Sea oats are better dune builders, but cordgrass is more common on Core Banks. Sea oats grow vigorously when the plants receive fresh sand and salt spray, their main source of nutrients (Woodhouse, Seneca, and Cooper, 1968).

Behind the dunes at Core Banks, storms of the last 20 years have left a series of flat overwash terraces (Godfrey, 1970). The highest terraces are the areas which have been overwashed most frequently. The distribution of plants found on these flats depends on the elevation of each terrace above sea level.

In the past, spit formation, beach progradation, and inlet closure have left a series of relic dune systems scattered along the Outer Banks. Where these dunes are far enough back from the sea to be protected from salt spray, they have been stabilized by maritime woodlands dominated by pine and oak forests (Oosting and Billings, 1942; Oosting, 1945). Typical maritime forests can be found on Shackleford Banks, scattered on Core Banks, and in the Cape Hatteras region, including Ocracoke Village, Buxton, Avon, and Nags Head. These forests probably were never continuous along the barrier islands.

The broad salt marshes that border the sound side of Core Banks form two basic patterns. The first is typically a band of marsh grass, 100 to 160 feet wide, that parallels the dune and grassland zones between the spring high tide mark and normal low tide. Smooth cordgrass (Spartina alterniflora) dominates the lower zone. This band of marsh develops on overwash terraces within reach of the tides. The most luxurious stands of marsh grass are now where overwash deposits fill part of the sound.

The second salt marsh pattern is on the complex of small islands immediately behind the main barrier island. There grasses develop on old tidal deltas left by former inlets (Fisher, 1962). Sometimes overwash fills in the sound, joining the marsh islands to the main barrier island. The islands have the same plant zones as the fringing marshes, except that black needlerush (Juncus roemerianus) may replace the cordgrasses in areas not regularly flooded by tides. 

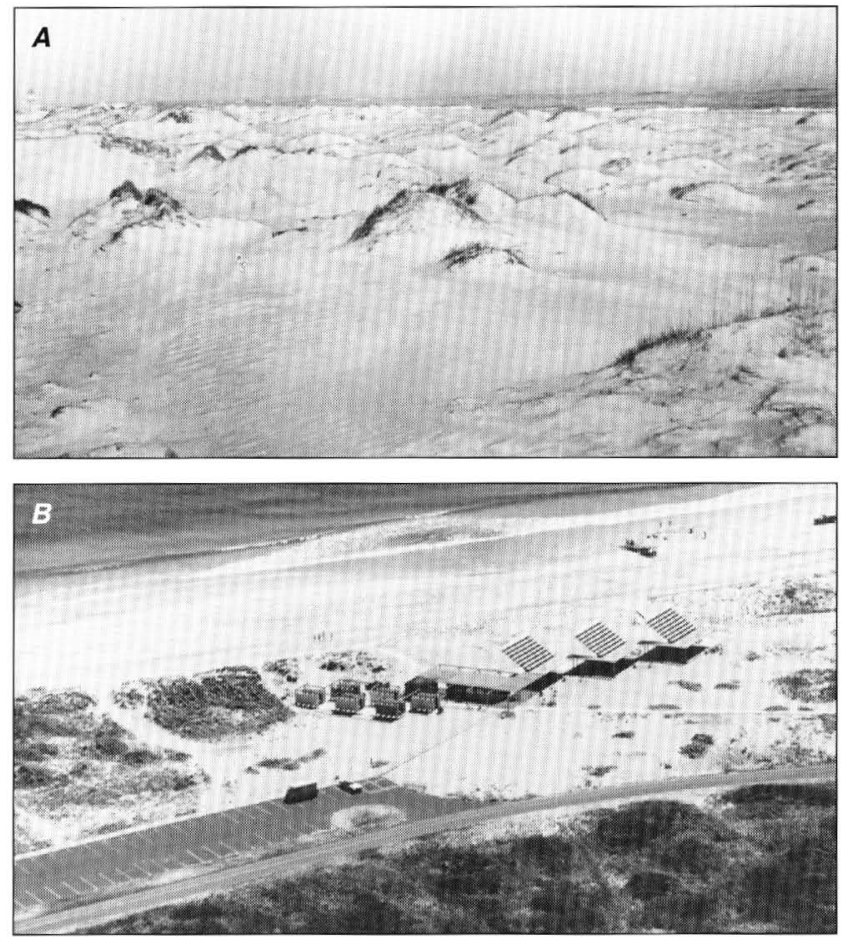

Figure 55. The history of shoreline stabilization at Coquina Beach on Bodie Island. A, The shore zone in 1955 before the National Park Service stabilized the active sand zone. B, The large comfort station soon after its completion in 1959. C, The same structure just before it was destroyed by storm surge in 1976. (Source: National Park Service.)
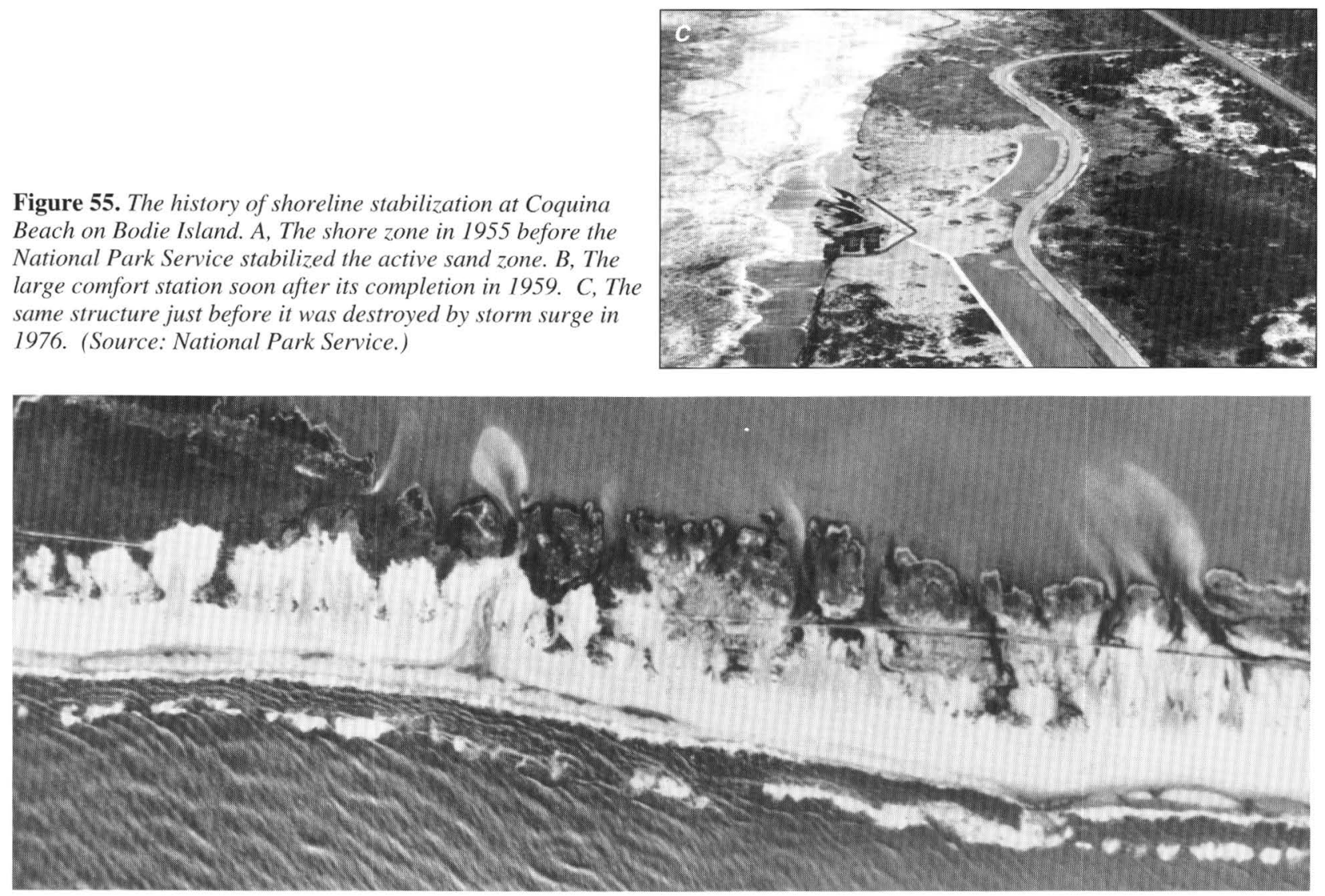

Figure 56. Overwash fans north of Cape Hatteras, 1972. (Source: National Park Service.) 
The frequency of severe storms along coastal North Carolina and their accompanying overwash precluded a permanent road network until the 1930's. At that time, it was decided to construct a protective dune system between the proposed road and the beach. Beginning in 1936, the Civilian Conservation Corps and the Work Projects Administration, under the direction of the National Park Service, erected almost 3.3 million feet of sand fencing to create a continuous barrier dune along the Outer Banks (fig. 57) including Hatteras, Pea, and Bodie Islands (Stratton and Hollowell, 1940).

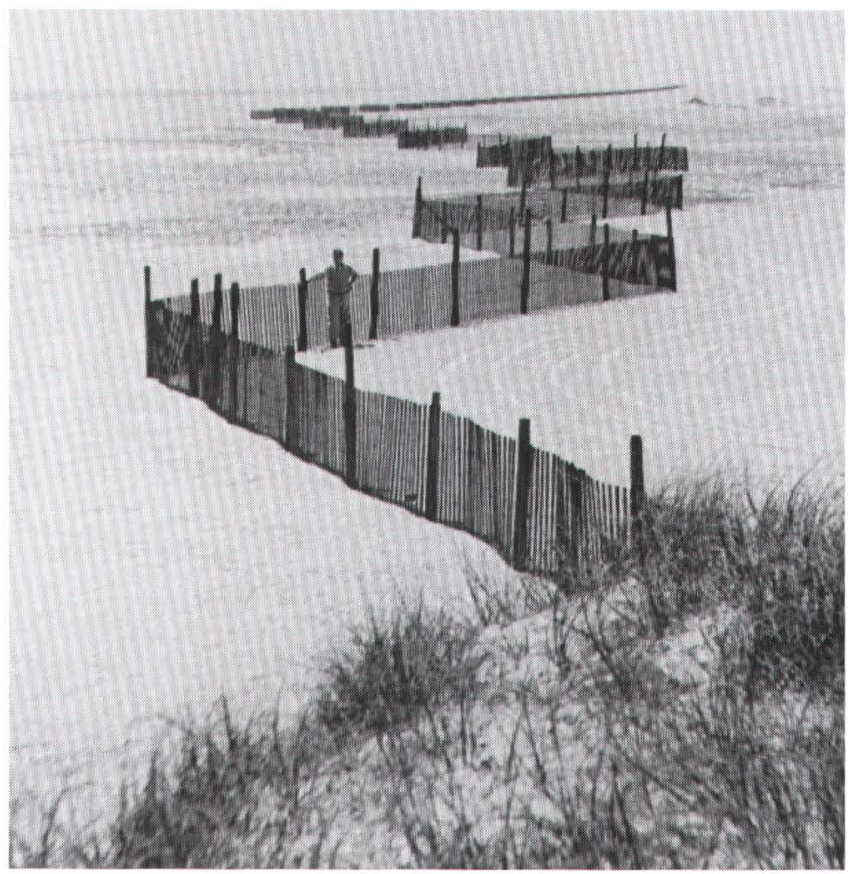

Figure 57. Sand fencing on Ocracoke Island. (Source: National Park Service.)

Most construction took place in the zone comprising the original low beach dunes and a strip 100 to 300 feet wide behind the foredune (fig. 54A). The sand that collected around the fencing was stabilized further with approximately 2.4 million trees and shrubs and enough grass to protect 3,254 acres. The National Park Service resumed the effort in dune construction in the late 1950's, and an almost continuous mass of vegetation from south Nags Head to the southern tip of Ocracoke Island has resulted. The most successful vegetation is American beach grass

(Ammophila breviligulata) and, to a lesser extent, sea oats (Woodhouse and Hanes, 1966).

Thirty years of artificial dune stabilization has altered greatly the ecology and geology of the area around Cape Hatteras (fig. 58). A comparison of a cross section of Hatteras Island, representing the altered condition, shows how stabilization has changed the beach, dune, and marsh morphology and established new plant communities (fig. 54B).

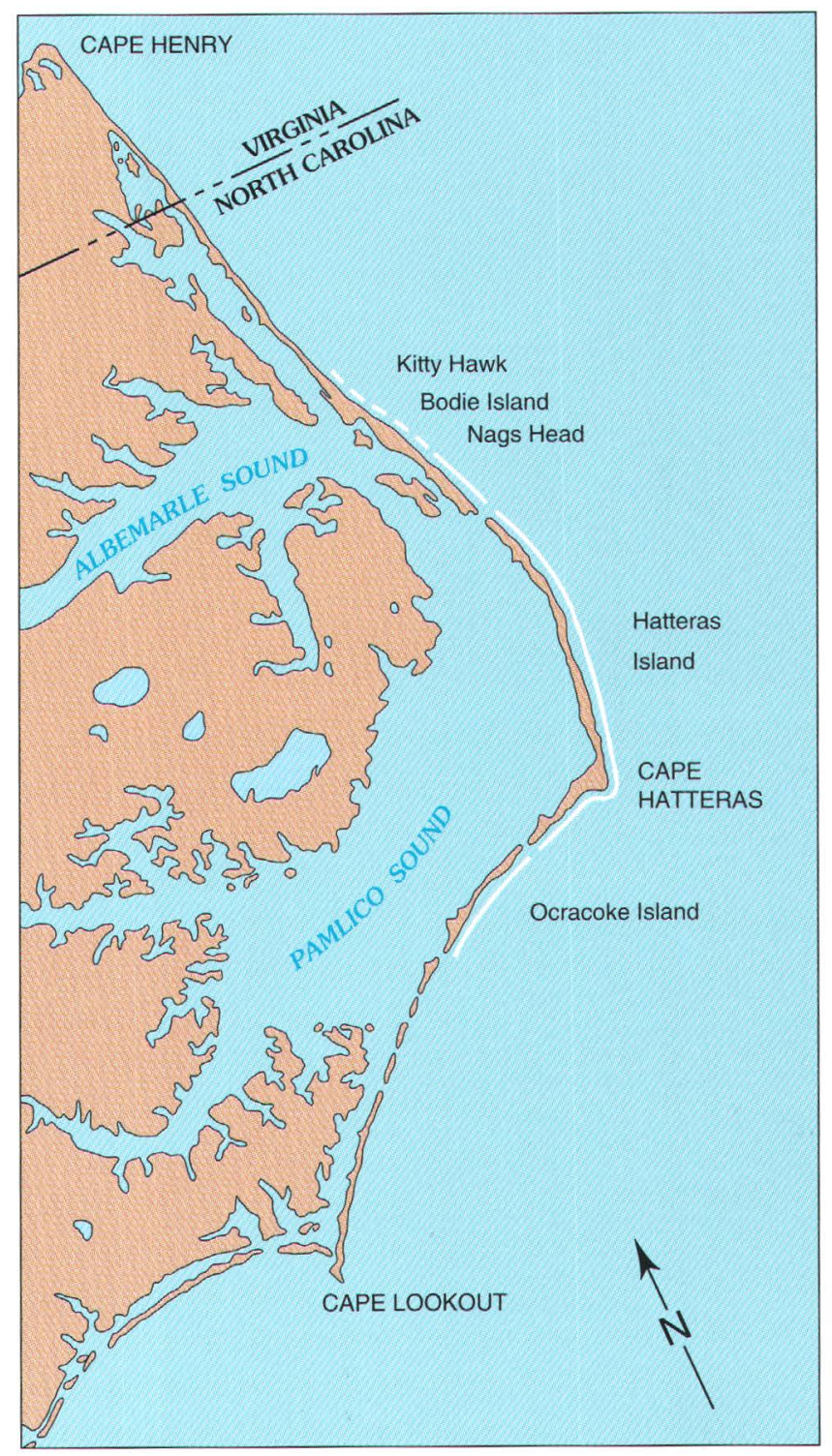

Figure 58. The location of stabilized parts of the North Carolina Outer Banks.

Viewed from the air, the most striking difference between the natural and altered barrier islands, other than the artificial barrier dune system, is a marked difference in beach widths (fig. 59). The unaltered islands have beaches 400 to 650 feet wide, averaging about 500 feet. On many stretches of the Hatteras Island beach, which was altered 30 years ago, the shore zone has receded to a width of 100 feet 
or less. Ocracoke Island, which was altered 10 to 15 years ago, has intermediate-width beaches ranging from 160 to 325 feet and averaging 250 feet.
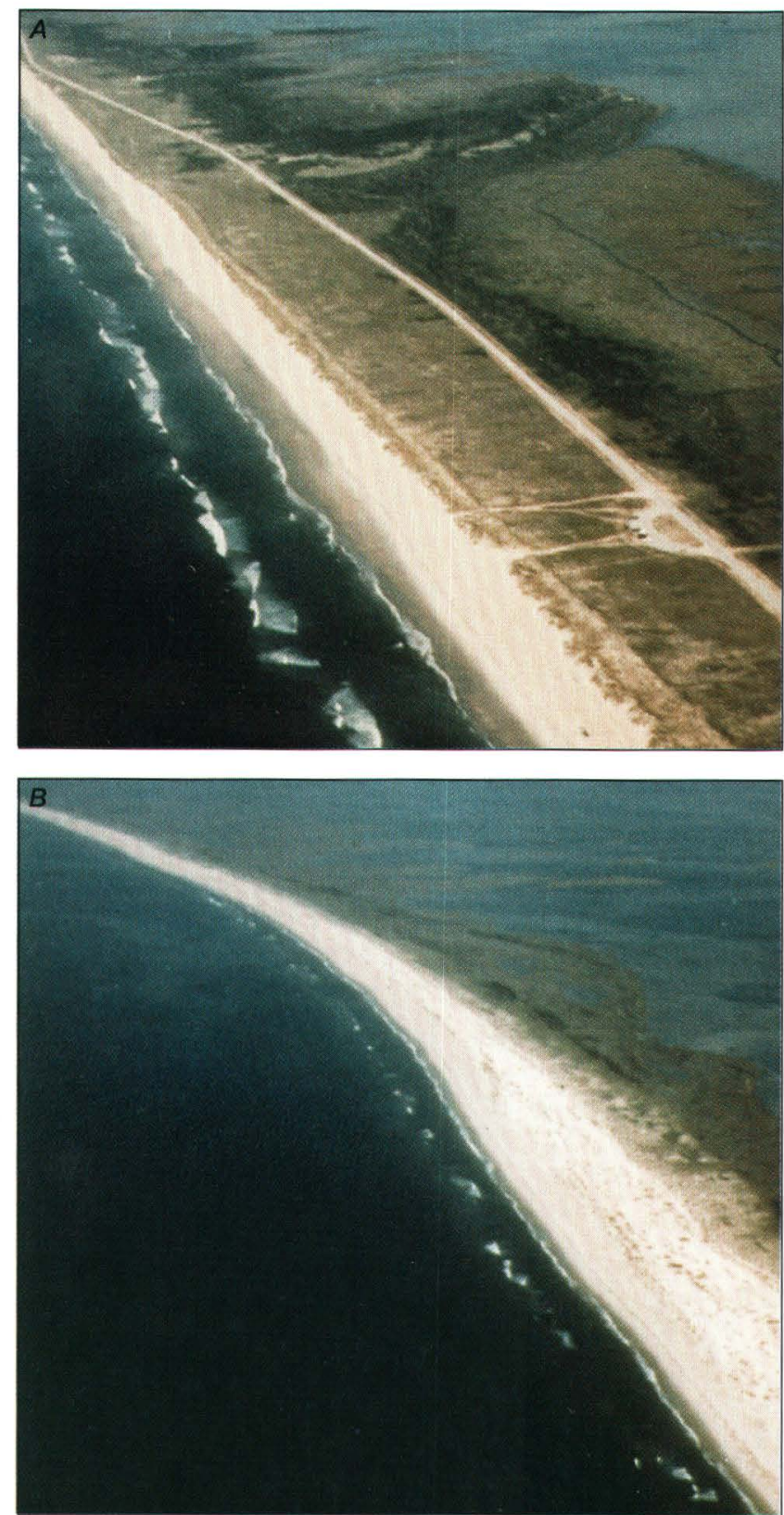

Figure 59. The difference in beach widths can be seen from these two photographs. A, Hatteras Island (stabilized), and B, Core Banks (unstabilized). (Source: R. Dolan.)

Few plants can tolerate the extreme conditions near a beach subject to high wave action. The effect of salt spray and occasional flooding on dune vegetation have been well documented (Boyce, 1954). One major difference between natural and stabilized barrier islands is the role played by the manmade dune in altering the normal vegetation sequence. As shown in figure 54, the dune and berm profiles of the two types of beach differ strikingly.

The stabilized dune line, as high as 30 feet in places, stops overwash and salt spray and enables plants, which usually grow farther away from the natural beach, to survive on its back slope. Among the plants progressing seaward because of dune stabilization are shrub communities that can form impenetrable thickets 10 to 15 feet high. This rapid expansion of shrubs can be seen best on Bodie Island (figs. 60, 61). Before the dunes were stabilized, a few shrubs grew in the drifting sand around Bodie Island Lighthouse near Oregon Inlet. By 1979, this same area was covered with a dense growth of shrubs, as was the entire center of the island. The U.S. Fish and Wildlife Service and the National Park Service have attempted to check the spread of shrubs with controlled fires (Dolan, 1972).

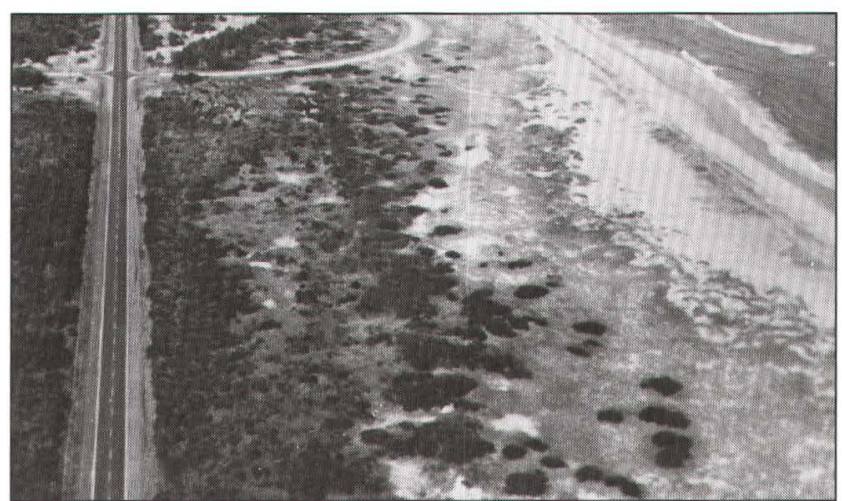

Figure 60. Pattern of shrub growth on Bodie Island. This area was mostly unvegetated sand flats before 1930. (Source: R. Dolan.)

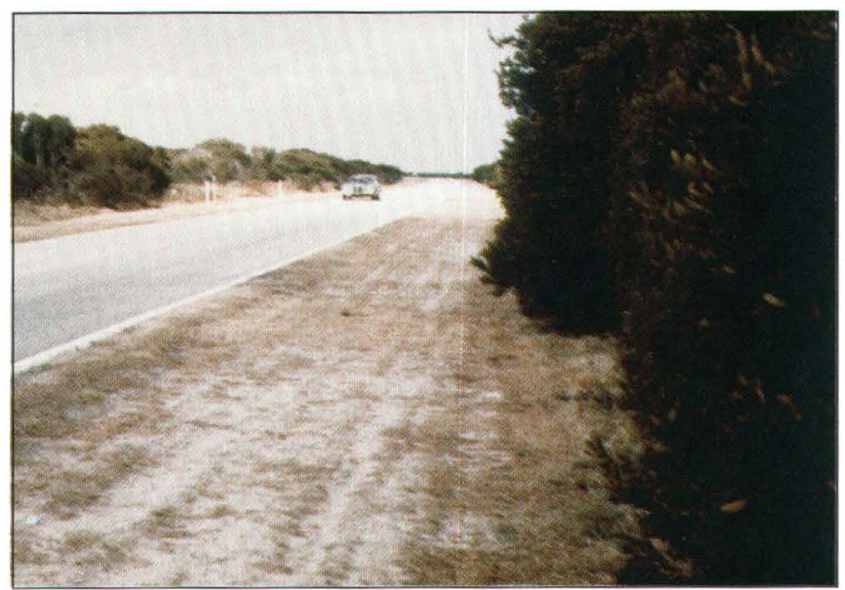

Figure 61. Shrub growth along Highway 12 on Bodie Island. (Source: R. Dolan.) 
The shrubs and other out-of-place species are not well adapted to flooding, burial from overwash, or salt spray. When the dunes are breached during a storm, these plants are killed. It is unknown how rapidly this vegetation will recover. On a natural barrier island, however, the indigenous plants that grow close to the sea can renew themselves within one growing season after an overwash.

Interference with the overwash processes and inlet dynamics cannot help but decrease the productivity of the sounds. In the past, new marsh areas have grown up on sand deposited in the sounds through temporary inlets, and marsh grasses have invaded the overwash sediment carried across the islands. Marshes can grow vertically by organic accumulation, but they cannot expand into the sound once the supply of overwash sand, the basis for gradual lateral growth, has been cut off. Instead, the marshes tend to have scarped and eroding edges. In fact, all the land behind the artificial dune accumulates organic matter very slowly, so that the land becomes lower with respect to the rising sea level once overwash deposition is stopped.

Another problem associated with dune stabilization in the Outer Banks is flooding that occurs when northeast storms pile the water of Pamlico Sound against the barrier islands. In the past, these surge waters simply flowed between the dunes and into the ocean. Now the water cannot drain off readily, and much of the land behind the stabilized dunes is submerged periodically. Hurricane winds from the southeast force elevated waters from the ocean into the sounds. When the storm moves off the coast, the winds shift to the northwest, and water piles up from the soundside. Wherever large barrier dunes are present, a hurricane causes severe beach erosion on the ocean side and floods on the sound side.

Further compounding the problem has been the false impression of safety and stability created by the barrier dune. Numerous structures-including motels, restaurants, beach cottages, park facilities, and the U.S. Naval Station at Cape Hatteras-have been built immediately behind the barrier dunes with the belief that the dunes would provide permanent protection from encroachment by the sea. Instead, the beach has narrowed steadily, and the barrier dunes subsequently have eroded away, leaving these structures with little protection against extreme storms (fig. 62).

The opening and closing of inlets and oceanic overwash create serious problems in maintaining a permanent highway down the center of the Outer Banks. In the past, the highways have been cleared when they were covered with sand deposited by overwash and have been rerouted several times when erosion destroyed or threatened the dunes. Bridges have been abandoned, and roads have been built where inlets have closed (fig. 63).

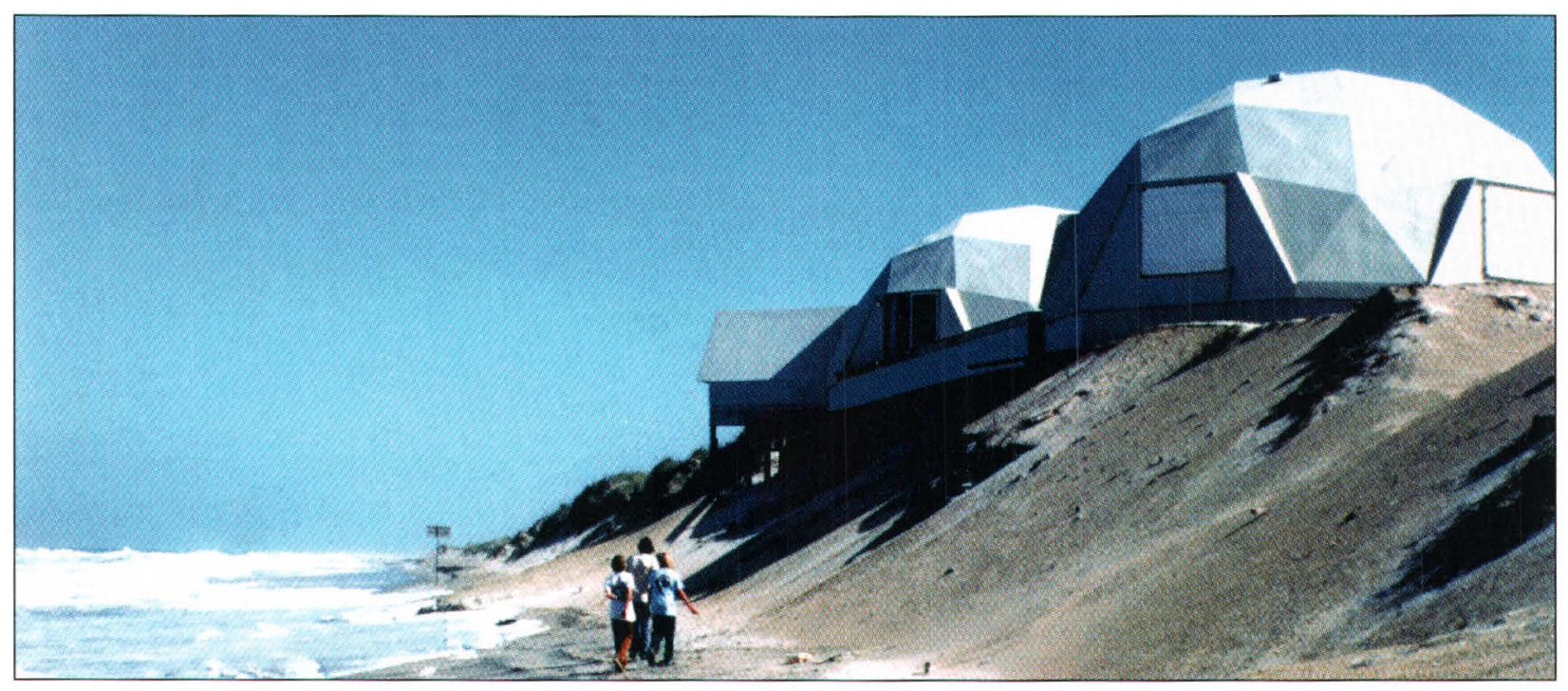

Figure 62. House on Bodie Island which was later moved back from the shoreline in 1980 with funds provided by the Federal Flood Insurance Program. (Source: R. Dolan.) 


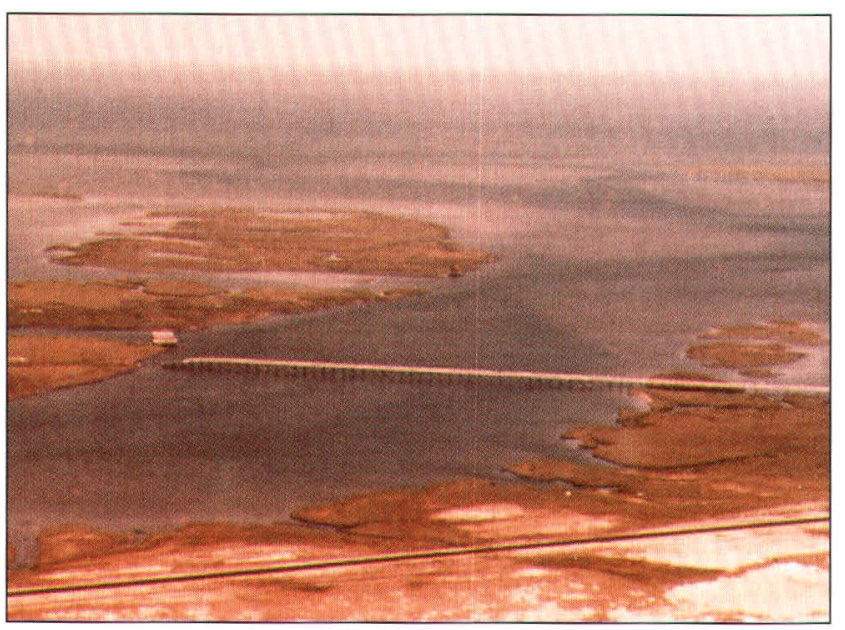

Figure 63. New inlet on Pea Island. The inlet was cut through the island in the 1930's but was sealed by natural processes before the bridge was used. (Source: R. Dolan.)

Although the present stabilized system is undependable, endangered, and expensive to maintain, alternatives are even more expensive and somewhat questionable in terms of application and economics. Attempts have been made to maintain the beaches by constructing groins or by dredging sediments and pumping them onto the beach. The cost of groin fields commonly runs into millions of dollars. Beach nourishment may cost $\$ 2$ million to $\$ 5$ million a mile, and, in most cases, they are only temporary measures.

Another suggested measure is a reinforced dune system at critical sites by forming seawalls of sand bags (fig. 64) and filling the center with loose sand. Construction of structures such as this ignores the basic fact that once the beach is gone, nothing will stop heavy surf for long. A better solution, and clearly the more desirable from ecological and geological standpoints, would be to construct an elevated highway on the sound side of the islands. This solution would allow natural processes to proceed with little resulting damage, although the cost may be prohibitive.

Cape Hatteras has been urbanized to the point where the present highway must be maintained (National Park Service, 1978). As the beach system continues to narrow, however, new instances of overwash, erosion of the artificial barrier dunes, and inlet formation can be forecast. Many structures that have been built near the beach will be lost, and the highway will require relocation in several places within a few years. The situation on Cape Lookout however is entirely different. The area from Portsmouth Island to Cape Lookout and west along

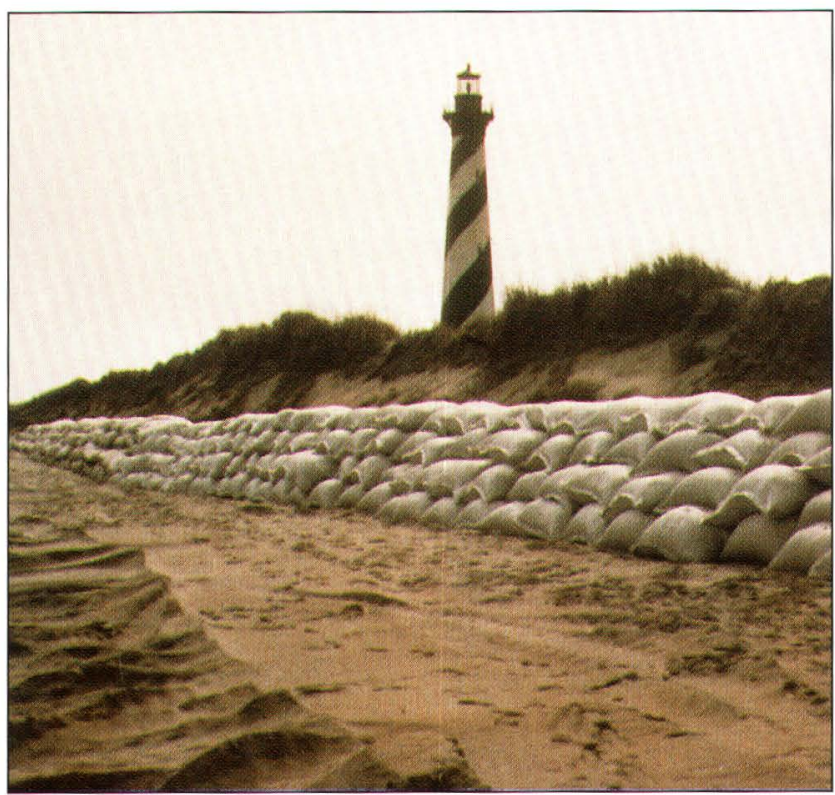

Figure 64. Sandbag seawall which was constructed at the base of the Cape Hatteras lighthouse. This structure was destroyed by wave action soon after it was completed. (Source: R. Dolan.)

Shackleford Banks is undeveloped. No highways, utilities, or permanent settlements are there to protect.

As early as 1938, National Park Service geologists asserted that the low, open nature of the Outer Banks was due to natural processes at work, not to deforestation. Between 1970 and 1973, Dolan and Godfrey presented their findings to the National Park Service contending that barrier islands were intrinsically unstable and that their natural response to stress was change, by either accretion or erosion (Dolan, Godfrey, and Odum, 1973). They advocated the termination of large-scale dune stabilization programs and held that such programs led to major modifications of the system and result in severe adjustments in geological and ecological processes (Dolan, 1973).

The National Park Service eventually adopted the philosophy of letting nature take its course (Behn and Clark, 1979). Too much money had been expended over the years with too few positive results. Upon completion of a beach nourishment project at Buxton in 1973, the Park Service outlined the new dune stabilization policy

"Following damaging storms, the dunes [will] not be artificially rebuilt, but in extensive barren areas a revegetation program [will] be initiated. Inlets which opened during storms [will] be permitted to migrate and close naturally. This alternative envisions that at some time in the future it may be impractical to maintain a continuous road through the seashore." 
The problem of beach erosion along the Outer Banks is rooted not so much in the patterns of land use introduced by the early settlers as much as in the rapid development which has occurred over the past four decades. During this period, the Outer Banks have been transformed from an area of open space and isolated fishing villages into a crowded resort area that has a summer population of close to 100,000 people per day. The result has been a rapid alteration of the natural environment.

\section{HAZARDS AND LAND USE}

Two important issues to consider in barrier island management are the hazards associated with erosion and with storm surge. Because of the continuing relative rise in sea level and the frequent impact of storm waves and surges, barrier islands are moving toward the mainland. The rate of movement for the Outer Banks over the last four decades has averaged between 3 to 5 feet per year. There is nothing to indicate that the natural processes that have been forcing barrier islands toward the mainland for many decades will soon change. On the basis of data on 20 to 40 years of shoreline change along the islands, if historical trends continue, a forecast of what the Outer Banks may look like in another 25 years can be made (Dolan, Hayden, and Heywood, 1978b). This forecast is based on the assumption that man will make no major alterations in the present system.

The complexity of barrier island dynamics precludes simple rule-of-thumb guidelines for land use management. Charts and maps that show the degree of vulnerability to extreme storms, the probable results of a rise in sea level, and the best possible forecasts of future conditions on the Outer Banks are presently among the most needed information tools. To be effective in a land use management program, these data would have to be updated continuously through systematic monitoring that includes repetitive aerial photography and fieldwork. Only through this method can nature's long-term dynamic trends be identified and the appropriate management decisions be implemented.

Changes in the shoreline at any point (landward or seaward) can be measured by the mean rate of change (long-term trend) and standard deviation of rate of change (periodic fluctuation). The sum of these two measures is one of the best indications of hazards and vulnerability or stability of the shoreline. The graphs in figure 65 are designed to provide rapid visual assessment of shoreline stability along the Outer Banks (Dolan, Hayden, and Heywood, 1978a). Perhaps more important than the absolute magnitude of erosion is the capacity to compare relative magnitudes of erosion from point to point and area to area. The means and standard deviations of shoreline rates of change for areas along the Outer Banks are given in table 2. As the graphs and table show, rates of change are highly variable quantities in space and time.

The following table lists the long-term average rates $(M)$ and the standard deviation $(S D)$ of shoreline change in meters per year for the Outer Banks barrier islands. A negative sign indicates recession, and a positive sign, accretion. $N_{\mathrm{i}}$ indicates the number of transacts for each island. [ Source: R. Dolan.]

Table 2. Shoreline rate of change statistics

\begin{tabular}{lll}
\hline \multicolumn{1}{c}{ Island } & $\boldsymbol{M}$ & $\boldsymbol{S} \boldsymbol{D}$ \\
\hline Shackleford: $N_{\mathrm{i}}=123$ & -0.97 & 2.74 \\
Core Banks: $N_{\mathrm{i}}=392$ & -0.22 & 2.02 \\
Portsmouth: $N_{\mathrm{i}}=220$ & -0.96 & 0.80 \\
Ocracoke: $N_{\mathrm{i}}=239$ & +0.59 & 3.11 \\
South Hatteras: $N_{\mathrm{i}}=175$ & +0.37 & 1.33 \\
North Hatteras: $N_{\mathrm{i}}=600$ & -1.94 & 1.96 \\
\hline
\end{tabular}

Beach protection and restoration are expensive measures that are generally beyond the means of the individual property owner. The best solution to beach erosion and flooding, therefore, is to plan carefully before building or buying beachfront property. Some basic factors to consider are the erosional history of the property and recent trends of shoreline change for the area; the magnitude of wave forces, storm surges, and storm frequencies; and the characteristics of the specific site in question, such as beach slope, beach width, dunes, and general topography.

An understanding of the relations among beach width, beach slope, and potential storm surge is needed so that buildings can be constructed with a knowledge of the probability of wave damage within a given number of years. For a building far inland, for 


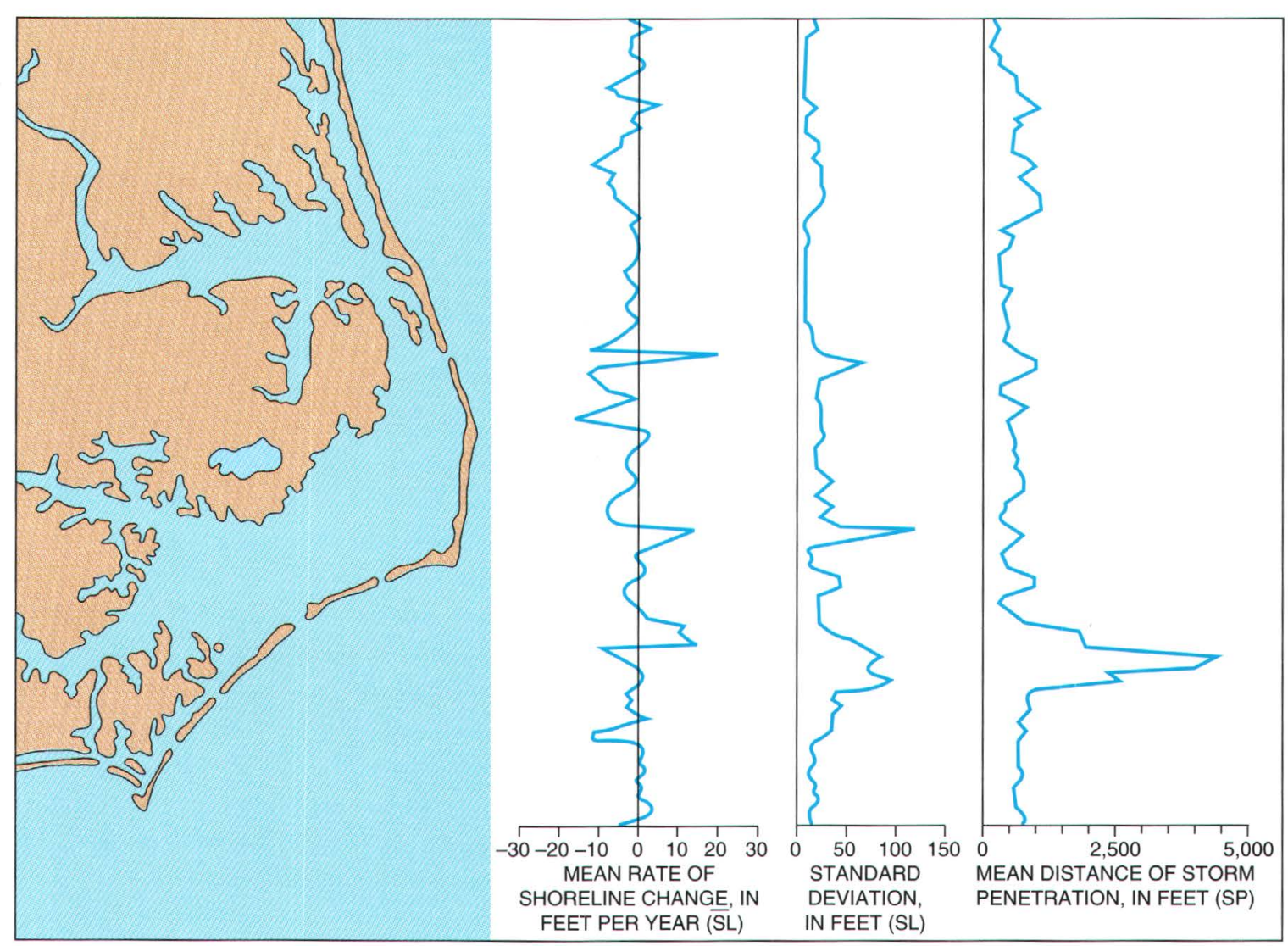

Figure 65. Data strips which permit rapid visual assessment of horizontal erosion along the Outer Banks.

example, storm damage may be of little concern. With each unit of distance one moves the building toward the beach, however, the probability of damage, within a given time period, increases (fig. 66). If the building is designed for a life expectancy of 15 years, it is poor planning to place it in a zone that has a high probability of storm-surge damage within 5 years. Design adjustments are possible that can change the probability; for example, a building fortified with a seawall and elevated on pilings above the storm-surge level could be constructed in an otherwise undesirable location within a storm-surge zone.

Few standardized guidelines or generalized rules of thumb are available for planning and managing land use on barrier islands and, likewise, for developing beach property. Every coastal site is different. Many costly failures have resulted when a workable solution for one beach was tried on another. Therefore, planning and developing each site should be treated as a unique problem having unique appropriate planning and design solutions (Pilkey, Neal, and Pilkey, 1978).

\section{SUMMARY AND CONCLUSIONS}

This report has presented an overview of the geological history of the Outer Banks of North Carolina-how the islands formed, how they have changed, and why they will continue to change in the future. It has included an assessment of man's activities which have occurred on the Outer Banks since the time of the first English settlements. The purpose has been to describe the natural processes and to point out that some of these processes result in environmental hazards. Data also have been presented on rates of shoreline change and storm overwash that can be used to estimate future positions of these dynamic components of the barrier island system.

Natural processes provide many clear indications of areas that are especially hazardous to develop. Data on erosion and overwash penetration rates, coupled with land use information, can provide a basis for guiding future development away from the more hazardous areas and into locations of greater relative safety. Similarly, such data can be used effectively to evaluate various hazard mitigation techniques and to 


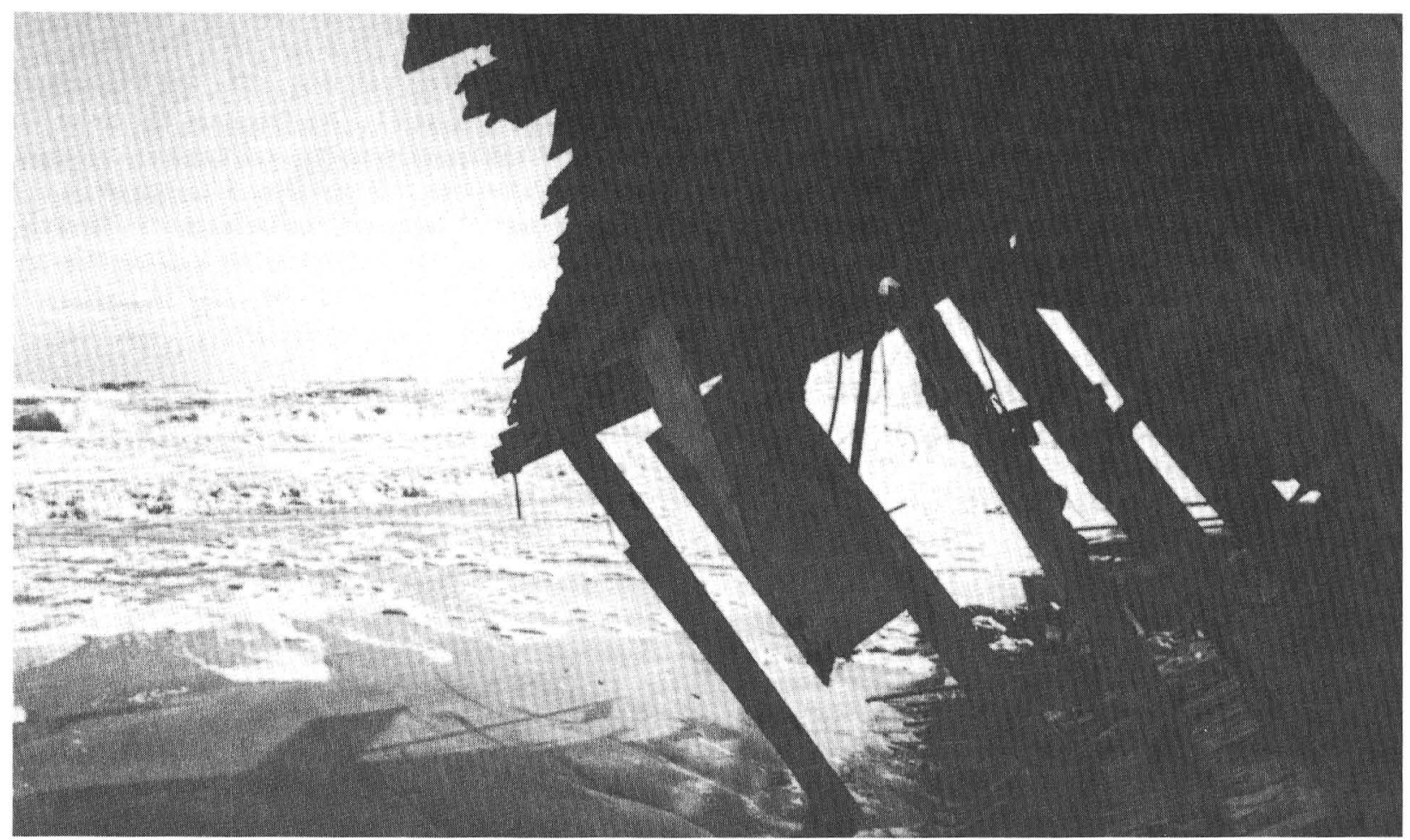

Figure 66. Potential property losses along the Atlantic Coast (over $\$ 100$ million) if another March 7, 1962, storm were to occur. (Source: A. Brown.)

choose those which offer the most protection with the fewest negative impacts.

The natural configuration of barrier island coastlines, as determined by coastal processes, is not a straight line but is rather sinuously curved and bulged. Some homes on the Outer Banks, constructed in the 1950 's, are still here today, having weathered hundreds of storms, including the destructive 1962 Ash Wednesday northeaster. Other houses nearby have disappeared. The vulnerability of some places along the coast is not simply a matter of chance. There are patterns to the hazards. Research suggests that even for individual sites along the barrier islands, natural processes result in shoreline forms that are systematic or recurring (Dolan and Hayden, 1980).

If hazard zones along the barrier islands are distributed systematically, then they should be predictable. The problem is that detailed historical information for establishing past patterns is not always available. Evidence suggests, however, that sections of sedimentary coasts which have experienced storm damage and serious erosion in the past are likely to experience more of the same in the future. We believe a natural "template of change" exists that is governed by the coastal configuration.
Inhabitants of barrier islands continually face the need to assess environmental processes and the associated potential for hazardous conditions. Such assessments are exceedingly complex. The probability of error is great because of the high temporal and spatial variance inherent within and among such factors as sea-level rise, storm frequency, shoreline erosion, and increasing residential density. Clearly, the hazard potential of a given location to individual storms needs to be gaged. However, precise predictions of when or where storms will occur is not possible. This does not mean that general assessments of along-the-coast variations in hazard probabilities are limited. Research indicates that the occurrence and impact of coastal storms differ more in intensity than in geography. It is possible that one of the most important elements in future hazard research and assessment is a concept which has so far been explored principally on an intuitive level; that is, that storms provide the energy for coastal change and that geomorphological characteristics determine how that energy is distributed. The quantification of this concept may offer significant possibilities for progress in the study of coastal hazards. 


\section{SELECTED REFERENCES}

Anderson, J.R., Hardy, E.E., Roach, J.T., and Witmer, R.E., 1976, A land use and land cover classification system for use with remote sensor data: U.S. Geological Survey, Professional Paper 964, 28 p.

Behn, R.D., and Clark, M.A., 1979, The termination of beach erosion control at Cape Hatteras: Public Policy, v. 27 , no. 1, p. 99-127.

Bosserman, K., and Dolan, R., 1968, The frequency and magnitude of extratropical storms along the Outer Banks of North Carolina: National Park Service Technical Reprint 68-4, 54 p.

Boyce, S.G., 1954, The salt spray community: Ecological Monographs, v. 24, p. 29-68.

Bretschneider, C.L., 1964, The Ash Wednesday East Coast storm, March 5-8, 1962, Proceedings of 9th Conference Coastal Engineering, American Society of Civil Engineers, New York: p. 167-659.

Brown, C.A., 1959, Vegetation of the Outer Banks of North Carolina: Baton Rouge, Louisiana, Louisiana Coastal Studies Series No. 4, Louisiana State University Press, $179 \mathrm{p}$.

Clark, J.R., and Turner, R., 1976, Barrier islands, a threatened fragile resource: Conservation Foundation Newsletter, no. 8, p. 1-11.

Cobb, C., 1903, Recent changes in the North Carolina coast with special reference to Hatteras Island: Science, v. 17, no. 423,227 p.

1908, The North Carolina coast, its perils and how they may be lessened: Proceedings, First Annual Convention, Atlantic Deeper Waterways Associations, p. 159-164.

Cooperman, A.I., and Rosendal, H.E., 1962, Great Atlantic Coast storm: Mariners Weather Log, U.S. Department of Commerce, Weather Bureau, v. 6, no. 3, p. 79-85.

Croft, L.P., 1934, Study for a national seaside, including Kill Devil Hills, Hatteras, Cape Lookout, Fort Macon area: Branch of Planning, National Park Service.

Curray, J.R., 1960, Sediments and history of Holocene transgression, continental shelf, northwest Gulf of Mexico, in Shepard F.P., ed., Recent sediments, northwest Gulf of Mexico: Tulsa, Oklahoma, American Association Petroleum Geologists, p. 221226.

Dillon, W.P., and Oldale, R.N., 1978, Late Quaternary sealevel curve: Geology, v. 6, p. 56-60.

Dolan, R., 1971, Coastal landforms, crescentic and rhythmic: Geological Society American Bulletin, v. 82 , p. $177-180$.

-1972 , Barrier dune systems along the Outer Banks of North Carolina, a reappraisal: Science, v. 176, p. 286-288.
1973, Barrier islands, natural and controlled, in Coates, D.R., ed., Coastal geomorphology: Binghamton, State University of New York, New York, p. 263-278.

Dolan, R., and Bosserman, K., 1972, Shoreline erosion and the lost colony: Association American Geographers, Annals, v. 62, no. 3, p. 424-426.

Dolan, R., and Glassen, R., 1972, Oregon Inlet, North Carolina, a history of coastal change: Southeastern Geography, v. 13, no. 1, p. 41-53.

Dolan, R., Godfrey, P.J., and Odum, W.E., 1973, Man's impact on the barrier islands of North Carolina: American Scientist, v. 61, p. 152-162.

Dolan, R., and Hayden, B., 1980, Templates of change, storms and shoreline hazards: Oceanus, v. 23, no. 4, p. 32-37.

Dolan, R., Hayden, B., and Lins, H., 1980, Barrier islands: American Scientist, v. 68, no. 1, p. 16-25.

Dolan, R., Hayden, B., and Felder, W., 1979, Shoreline periodicities and edge waves: Journal of Geology, v. 87 , p. $175-185$.

Dolan, R., Hayden, B., Fisher, J., and Godfrey, P.J., 1973, A strategy for management of marine and lake systems within the National Park Service: U.S. Department of Interior, National Park Service, National Science report $6,40 \mathrm{p}$.

Dolan, R., Hayden, B., and Heywood, J., 1978a, A new photogrammetric method for determining shoreline erosion: Coastal Engineering, v. 2, p. 21-39.

1978b, Analysis of coastal erosion and storm surge hazards: Coastal Engineering, v. 2, p. 41-53.

Dolan, R., Hayden, B., Heywood, J., and Vincent, L., 1977, Shoreline forms and shoreline dynamics: Science, v. 197 , p. $49-51$.

Dolan, R., Hayden, B., and Jones, C., 1979, Barrier island configuration: Science, v. 204, no. 4391, p. 401-403.

Dolan, R., Hayden, B., Rea, C., and Heywood, J., 1979, Shoreline erosion rates along the middle Atlantic coast of the United States: Geology, v. 7, p. 602-606.

Dolan, R., Hayden, B., and Vincent, L., 1974, Crescentic coastal landforms: Zeitschrift für Geomorphologie, v. 18 , no. 1 , p. $1-12$.

Dolan, R., and Vincent, L., 1972, Analysis of shoreline change at Cape Hatteras, North Carolina: Modern Geology, v. 3, p. 143-149.

Donn, W.L., Farrand, W.R., and Ewing, M., 1962, Pleistocene ice volumes and sea-level lowering: Journal of Geology, v. 70, p. 206-214.

Duane, D.B., Field, M.E., Meisburger, E.P., and others, 1972, Linear shoals on the Atlantic inner continental shelf, Long Island to Florida, in Swift, D.J.P. and others, eds., Shelf sediment transport, process and pattern: Stroudsburg, Pennsylvania, Dowden, Hutchinson, and Ross, p. 447-498. 
Dunbar, G.S., 1958, Historical geography of the North Carolina Outer Banks: Baton Rouge, Louisiana, Louisiana State University Press, 234 p.

Dunn, G.E., and Miller, B.I., 1960, Atlantic hurricanes: Baton Rouge, Louisiana, Louisiana State University Press, $326 \mathrm{p}$.

Emery, K.O., 1968, Relict sediments on continental shelves of the world: American Association of Petroleum Geologists Bulletin, v. 52, p. 445-464.

Emiliani, C., 1970, Pleistocene paleotemperatures: Science, v. 168, p. $822-825$.

Everts, H., Battley, J.P. Jr., and Gibson, P.N., 1983, Shoreline movements, Report 1 Cape Henry, Virginia, to Cape Hatteras, North Carolina, p. 1849-1980.

Field, M.E., and Duane, D.B., 1976, Post-Pleistocene history of the United States inner continental shelf, significance to origin of barrier islands: Geological Society of America Bulletin, v. 87, p. 691-702.

Field, M.E., Meisburger, E.P., Stanley, E.A., and Williams, S.J., 1979, Upper Quaternary peat deposits on the Atlantic inner shelf of the United States: Geological Society of America Bulletin, v. 90, p. 618-628.

Fisher, J.J., 1962, Geomorphic expression of former inlets along the Outer Banks of North Carolina: Chapel Hill, North Carolina, University of North Carolina, MS Thesis, $102 \mathrm{p}$.

1968, Origin of barrier island chain shorelines, Middle Atlantic States (Abstract): Geological Society of America Special Paper 115, [1967], p. 66-67.

Fisher, J.J., and Simpson, E.J., 1979, Washover and tidal sedimentation rates as environmental factors in development of a transgressive barrier shoreline, in Leatherman, S.P., ed., Barrier islands: New York, Academic Press, p. 127-148.

Frank, R.A., 1979, Living with coastal storms-Seeking an accommodation: National Conference on Hurricanes and Coastal Storms, Orlando, Florida, May 29; National Oceanographic and Atmospheric Administration, Washington, D.C., p. 18-20.

Godfrey, P.J., 1970, Oceanic overwash and its ecological implications on the Outer Banks of North Carolina: U.S. Department of Interior, National Park Service Reprint, Office of Chief Scientists, 37 p.

1972a, Ecological approach to dune management in the natural recreation areas of the U.S. East Coast: Noorwijk, The Netherlands, Sixth International Society Biometeorologists Congress, September 5 , 1972, 8 p.

$-1972 b$, Ecology of barrier islands influenced by man: Washington, D.C., American Association for the Advancement of Science Conference, December 30, 1972, 9 p.
$1972 \mathrm{c}$, The role of overwash and inlet dynamics in the formation of salt marshes on North Carolina barrier islands: Minneapolis, Minnesota, Twenty-third American Institute of Biological Sciences Management, August 30, 1972, $10 \mathrm{p}$.

1976, Barrier beaches of the East Coast: Oceanus, v. 19 , no. 5 , p. $27-40$.

Godfrey, P.J., Leatherman, S.P., and Zaremba, R., 1979, A geobotanical approach to classification of barrier beach systems, in Leatherman, S.P., ed., Barrier islands: New York, Academic Press, p. 99-126.

Harrington, J.C., 1962, Search for the City of Raleigh: U.S. Department of Interior, National Park Service, $63 \mathrm{p}$.

Hart, J.F., 1975, The look of the land: Englewood Cliffs, New Jersey, Prentice Hall, 224 p.

Hayden, B., 1975, Storm wave climates at Cape Hatteras, North Carolina, recent secular variations: Science, v. 190, p. 981-983.

Hayden, B., and Dolan, R., 1979, Barrier islands, lagoons, and marshes: Journal of Sedimentary Petrology, v. 49, no. 4, p. 1061-1072.

Hayden, B., Dolan, R., and Ross, P., 1979, Barrier island migration: Proceedings, Ninth Coastal Geomorphological Symposium: Stroudsburg, Pennsylvania, Dowden and Culver, p. 363-384.

1980, Barrier island migration, in Coates, D.R. and Vitek, J.D., eds., Thresholds in geomorphology: George Allen and Unwin, London, Boston, and Sydney, p. 343-384.

Hebert, P.J. and Taylor, G., 1979, Everything you always wanted to know about hurricanes, Part I: Weatherwise, v. 32 , no. 2 , p. $61-67$.

-1979 , Everything you always wanted to know about hurricanes, Part II: Weatherwise, v. 32, no. 3, p. 100-107.

Hicks, S.D., 1972, On the classification and trends of longperiod sea-level series: Shore and Beach, v. 40, no. 1, p. 20-23.

Hicks, S.D., and Crosby, J.E., 1975, An average long-period sea-level series for the United States: U.S. Department of Commerce, National Oceanographic and Atmospheric Administration Technical Memorandum of National Ocean Survey, no. 15, 6 p.

Holland, F.R., Jr., 1968, A survey history of Cape Lookout National Seashore: U.S. Department of Interior, National Park Service, $50 \mathrm{p}$.

Hosier, P.E., and Cleary, W.J., 1977, Cyclic geomorphic patterns of washover on a barrier island in southeastern North Carolina: Environmental Geology, v. 2, p. 23-31. 
Hoyt, J.H., 1967, Barrier island formation: Geological Society of America Bulletin, v. 78, p. 1125-1136.

Hoyt, J.H., and Henry, V.J., 1967, Influence of island migration on barrier island sedimentation: Geological Society of America Bulletin, v. 78, p. 77-78.

1971 , Origin of capes and shoals along the Southeastern Coast of the United States: Geological Society of America Bulletin, v. 82, p. 59-66.

Hughes, P., 1979, The great Galveston hurricane: Weatherwise, v. 32, no. 4, p. 148-156.

Knowles, C.E., Langfelder, J., and McDonald, R., 1973, A preliminary study of storm-induced beach erosion for North Carolina: Raleigh, North Carolina, Center of Marine Coastal Research, North Carolina State University, Reprint 73-75, $14 \mathrm{p}$.

Kraft, J.C., 1971, Sedimentary environment facies patterns and geologic history of a Holocene marine transgression: Geological Society of America Bulletin, v. 82, p. 2131-2158.

Kraft, J.C., Allen, E.A., Belknap, D.F., John, D.J., and Maurmeyer, E.M., 1976, Delaware's changing shoreline: Dover, Delaware, Delaware State Planning Office, $319 \mathrm{p}$.

Kraft, J.C., Biggs, R., and Halsey, S., 1973, Morphology and vertical sedimentary sequence models in Holocene transgressive barrier systems, in Coates, D.R., ed., Coastal geomorphology: Binghamton, New York, State University of New York, p. 321-354.

Langfelder, L.J., Stafford, D.B., and Amein, M., 1968, A reconnaissance of coastal erosion in North Carolina-A report prepared for the State of North Carolina: Department of Civil Engineering, Project ERD-238, North Carolina State University, 126 p.

Leatherman, S.P., Godfrey, P.J., and Buckley, P.A., 1978, Management strategies for national seashores: San Francisco, California, Proceedings, Technical, Environmental, Socioeconomic, and Regulatory Aspects of Coastal Zone Planning and Management Symposium, p. 322-337.

Leatherman, S.P., 1979, Barrier island handbook: National Park Service, Cooperative Research Unit, University of Massachusetts at Amherst, $101 \mathrm{p}$.

Lins, H.F., 1980, Patterns and trends of land use and land cover on Atlantic and Gulf Coast barrier islands: U.S. Geological Survey, Professional Paper 1156, $164 \mathrm{p}$.

Livingston, R.J., 1976, Diurnal and seasonal fluctuations of organisms in a north Florida estuary: Estuarine and Coastal Marine Research, v. 4, p. 373-400.

Miller, H.C., 1976, Barrier islands, barrier beaches, and the National Flood Insurance Program, in Barrier islands and beaches: Technical Proceedings, 1976 Barrier Islands Workshop, May 17-18, 1976, Annapolis, Maryland, Conservation Foundation, p. 127-139.
Moslow, T.F., and Heron, S.D., Jr., 1978, Relict inlets, preservation and occurrence in the Holocene statigraphy of southern Core Banks, North Carolina: Journal of Sedimentary Petrology, v. 48, no. 4, p. 1275-1286.

1979, Quaternary evolution of Core Banks, North Carolina: Cape Lookout to New Drum Inlet, in Leatherman, S.P., ed., Barrier islands: New York, Academic Press, p. 211-236.

National Park Service, 1978, Environmental assessment, Cape Hatteras National Seashore, North Carolina: U.S. Department of Interior, National Park Service, Denver Service Center, $150 \mathrm{p}$.

Oosting, H.J., 1945, Tolerance to salt spray of plants of coastal dunes: Ecology, v. 26, p. 85-89.

Oosting, H.J., and Billings, W.D., 1942, Factors affecting vegetational zonation on coastal dunes: Ecology, v. 23, p. 131-142.

Otvos, E.G., Jr., 1970, Development and migration of barrier islands, northern Gulf of Mexico: Geological Society of America Bulletin, v. 81, p. 241-246.

Outlaw, E.R., Jr., 1956, Old Nag's Head: Norfolk, Virginia, Lisky Lithograph Corporation, $64 \mathrm{p}$.

Pierce, J.W., 1969, Sediment budget along a barrier island chain: Sedimentary Geology, v. 3, p. 5-16.

1970, Tidal inlets and washover fans: Journal of Geology, v. 78, p. 230-234.

Pierce J.W., and Colquhoun, D.J., 1970, Holcene evolution of a portion of the North Carolina coast: Geological Society of America Bulletin, v. 81, p. 3697-3714.

Pilkey, O.H., Jr., Neal, W.J., and Pilkey, O.H., Sr., 1978, From Currituck to Calabash: North Carolina Science Technical Research Center, 228 p.

Podufaly, E.T., 1962, Operation five-high: Shore and Beach, v. 30, no. 2, p. 9-18.

Roush, J.F., 1968, Cape Hatteras National Seashore, North Carolina historical research management plan: U.S. Department of Interior, National Park Service, $53 \mathrm{p}$.

Schwartz, M.L., 1971, The multiple causality of barrier islands: Journal of Geology, v. 79, p. 91-94. -1973, Barrier islands: Stroudsburg, Pennsylvania, Dowden, Hutchinson, and Ross, Inc., 451 p.

Schwartz, R.K., 1975, Nature and genesis of some storm washover deposits: U.S. Army Corps of Engineers, Coastal Engineering Research Center, Technical Memorandum 61, $69 \mathrm{p}$.

Shepard, F.P., ed., 1962, Recent sediments, northwest Gulf of Mexico, Gulf Coast barriers: Tulsa, Oklahoma, American Association of Petroleum Geologists, p. 197-220.

Shepard, F.P., and Wanless, H.R., 1971, Our changing coastline: New York, McGraw-Hill, 579 p.

Sonu, C.J., 1973, Three-dimensional beach changes: Journal of Geology, v. 81, p. 42-84. 
Soucie, G., 1977, The need for a boat: National Parks and Conservation Magazine, v. 51, no. 2, p. 4-7.

Stewart, J.W., 1962, The great Atlantic Coast tides of March, 1962: Weatherwise, v. 15, no. 3, p. 117-120.

Stick, D., 1958, The Outer Banks of North Carolina, 15841958: Chapel Hill, North Carolina, University of North Carolina Press, $352 \mathrm{p}$.

Stratton, A.C., and Hollowell, J.R., 1940, Sand fixation and beach erosion control: U.S. Department of Interior, National Park Service, Office of Chief Scientist, 102 p.

Swift, D.J.P., 1968, Coastal erosion and transgressive statigraphy: Journal of Geology, v. 76, p. 444-456. 1975, Barrier island genesis, evidence from the central Atlantic shelf, eastern U.S.A.: Sedimentary Geology, v. 14, p. 1-43.

Technical Report CERC 83-1, U.S. Army Engineer Waterways Experiment Station, Coastal Engineering Research Center, Vicksburg, Mississippi, 113 p.

Toll, R.W., 1934, Report on Cape Hatteras ocean beach project to the Director: U.S. Department of Interior, National Park Service, Unpublished report, 8 p.

U.S. Army Coastal Engineering Research Center, 1973, Shore protection manual, Volume I, Washington, D.C., Superintendent of Documents, U.S. Government Printing Office, $510 \mathrm{p}$.
1975, Shore protection manual, Volume II: Washington, D.C., Superintendent of Documents, U.S. Government Printing Office, 538 p.

U.S. Army Corps of Engineers, 1962, North Carolina coastal areas, storm of 6-8 March, 1962 (Ash Wednesday storm): Wilmington, North Carolina, U.S. Army Engineers District, Final Post-Flood Reprint (RCSENGCW-0-2).

U.S. Department of the Interior, 1980, Alternative policies for protecting barrier islands along the Atlantic and Gulf Coasts of the United States and draft environmental impact statement: $142 \mathrm{p}$.

Wood, F.J., 1976, The strategic role of perigean spring tides: U.S. Department of Commerce, National Oceanographic and Atmospheric Administration, $538 \mathrm{p}$.

Woodhouse, W.W., and Hanes, R.E., 1966, Dune stabilization with vegetation on the Outer Banks of North Carolina: Raleigh, North Carolina, Soil Information Series, no. 8, Department of Soil Science, North Carolina State University, $50 \mathrm{p}$.

Woodhouse, W.W., Seneca, E.D., and Cooper, A.W., 1968, Use of sea oats for dune stabilization in the Southeast: Shore and Beach, v. 36, no. 2, p. 15-22. 

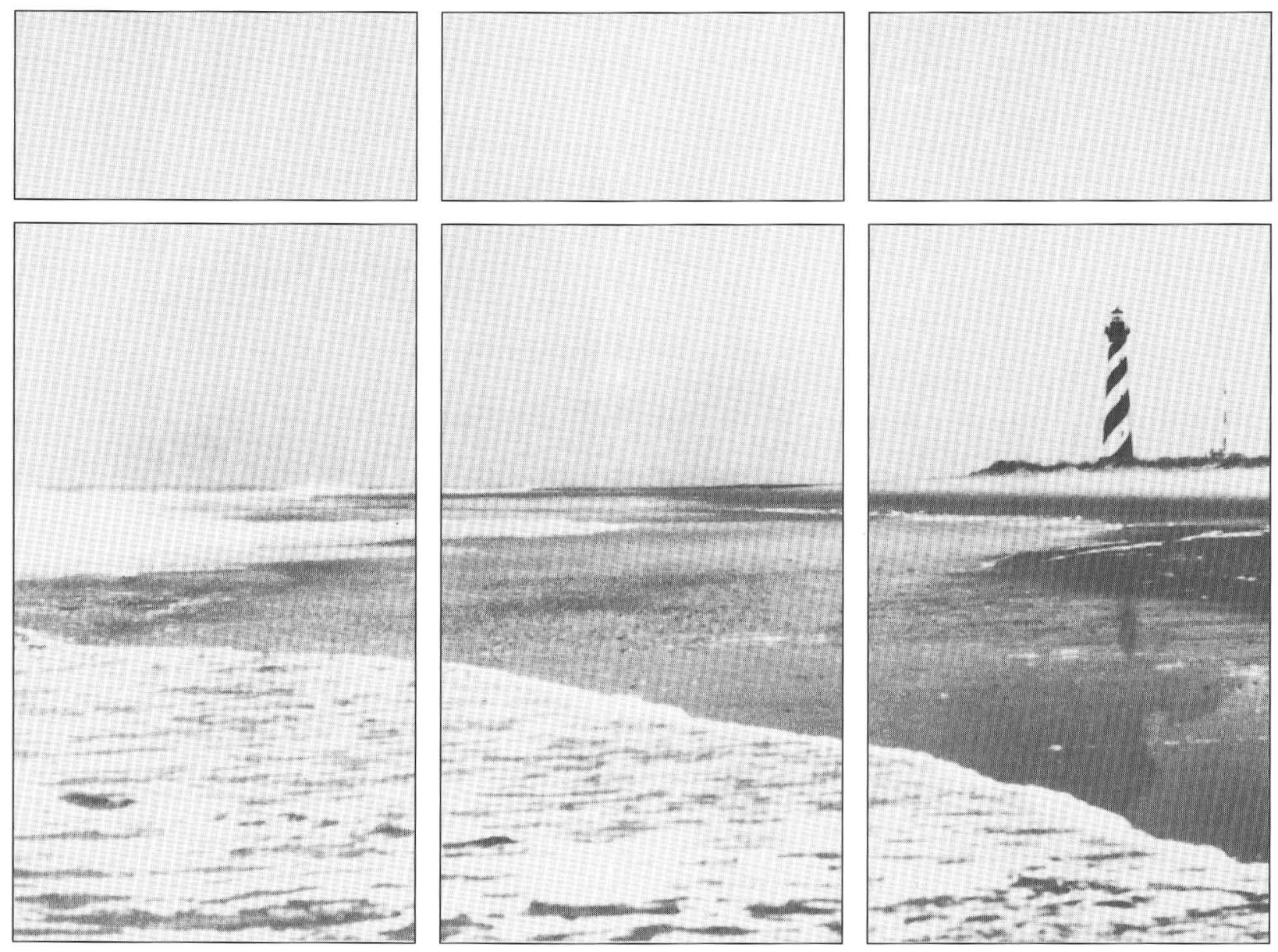